\title{
1 A robust approach to estimate relative phytoplankton cell 2 abundance from metagenomes
}

4 Running title: Relative phytoplankton abundance from metagenomes

6 Juan José Pierella Karlusich ${ }^{1,2}$ *, Eric Pelletier ${ }^{2,3}$, Lucie Zinger ${ }^{1,2}$, Fabien Lombard ${ }^{2,4,5}$,

7 Adriana Zingone ${ }^{6}$, Sébastien Colin ${ }^{7,8,9}$, Josep M. Gasol ${ }^{10}$, Richard G. Dorrell ${ }^{1}$,

8 Eleonora Scalco ${ }^{6}$, Silvia G. Acinas ${ }^{10}$, Patrick Wincker $^{2,3}$, Colomban de Vargas $^{2,8}$,

9 Chris Bowler ${ }^{1,2}$ *

$10{ }^{1}$ Institut de Biologie de l'ENS (IBENS), Département de biologie, École normale supérieure,

11 CNRS, INSERM, Université PSL, 75005 Paris, France

$12{ }^{2}$ CNRS Research Federation for the study of Global Ocean Systems Ecology and Evolution,

13 FR2022/Tara Oceans GOSEE, 3 rue Michel-Ange, 75016 Paris, France

$14{ }^{3}$ Génomique Métabolique, Genoscope, Institut François Jacob, CEA, CNRS, Univ Evry,

15 Université Paris-Saclay, 91057 Evry, France

$16{ }^{4}$ Sorbonne Universités, CNRS, Laboratoire d'Océanographie de Villefranche (LOV), 06230

17 Villefranche-sur-Mer, France

$18{ }^{5}$ Institut Universitaire de France (IUF), Paris, France

$19{ }^{6}$ Stazione Zoologica Anton Dohrn, Villa Comunale, 80121 Naples, Italy

$20{ }^{7}$ European Molecular Biology Laboratory, Heidelberg, Germany

$21{ }^{8}$ Sorbonne Université, CNRS, Station Biologique de Roscoff, UMR 7144, ECOMAP, 29680

22 Roscoff, France

$23{ }^{9}$ Max Planck Institute for Developmental Biology, Tübingen, Germany

$24{ }^{10}$ Department of Marine Biology and Oceanography, Institut de Ciènces del Mar, CSIC,

25 Barcelona, Spain

26

27

Chris Bowler (cbowler@biologie.ens.fr) 
Abstract

33 Phytoplankton account for $>45 \%$ of global primary production, and have an

34 enormous impact on aquatic food webs and on the entire Earth System. Their

35 members are found among prokaryotes (cyanobacteria) and multiple eukaryotic

36 lineages containing chloroplasts. Phytoplankton communities are generally studied

37 by PCR amplification of bacterial (16S), nuclear (18S) or chloroplastic (16S) rRNA

38 marker genes from DNA extracted from environmental samples. However, our

39 appreciation of phytoplankton abundance or biomass is limited by PCR-amplification

40 biases, rRNA gene copy number variations across taxa, and the fact that rRNA

41 genes do not provide insights into metabolic traits such as photosynthesis. In

42 addition, rRNA marker genes fail to capture both cyanobacteria and photosynthetic

43 eukaryotes simultaneously. Here, we targeted the photosynthetic gene psbO from

44 metagenomes to circumvent these limitations: the method is PCR-free, and the gene

45 is universally and exclusively present in photosynthetic prokaryotes and eukaryotes,

46 mainly in one copy per genome. We applied and validated this new strategy with the

47 Tara Oceans datasets, and showed improved correlations with flow cytometry and

48 microscopy than when based on rRNA genes. Furthermore, we revealed unexpected

49 features of the ecology of these organisms, such as the high abundance of

50 picocyanobacterial aggregates and symbionts in the ocean, and the decrease in

51 relative abundance of phototrophs towards the larger size classes of marine

52 dinoflagellates. To facilitate the incorporation of $p s b O$ in molecular-based surveys,

53 we compiled a curated database of $>18,000$ unique sequences. Overall, $p s b O$

54 appears to be a promising new gene marker for molecular-based evaluations of

55 entire phytoplankton communities. 
56 Keywords: photosynthesis, phytoplankton, psbO, V9-18S rRNA, metabarcoding,

57 metagenomics, metatranscriptomics, Tara Oceans

Introduction

Photosynthetic plankton, or phytoplankton, consist of unicellular organisms of

61 diverse evolutionary history and ecology. They are responsible for more than $45 \%$ of

62 Earth's primary production (Field, Behrenfeld, Randerson, \& Falkowski, 1998), fueling

63 aquatic food webs, microbial decomposition, and the global ocean biological carbon

64 pump (Guidi et al., 2009). They include prokaryotes (cyanobacteria) and multiple eukaryotic lineages that acquired photosynthesis either through the primary endosymbiosis of cyanobacteria, or (and predominantly) through secondary and

67 higher endosymbioses of eukaryotic algae (Pierella Karlusich, Ibarbalz, \& Bowler, 2020). They display a broad body size spectrum, from less than 1 micron (e.g., Prochlorococcus, Ostreococcus) to several millimetres (e.g., Trichodesmium colonies, colonial green algae, and chain-forming diatoms), either due to cell size variation, aggregation or symbioses (Beardall et al., 2009). This size variability partly explains their different roles in the food web and in the biological carbon pump. For example, cyanobacteria are generally thought to be recycled within the microbial

74 loop, whereas larger eukaryotic phytoplankton are usually considered more important in energy transfer to higher trophic levels (through grazing by small protists, zooplankton, and/or larvae (Ullah, Nagelkerken, Goldenberg, \& Fordham, 2018)) and

77 in sequestering atmospheric $\mathrm{CO}_{2}$ to the ocean interior through gravitational sinking of particles (Guidi et al., 2009). 
bioRxiv preprint doi: https://doi. org/10.1101/2021.05.28.446125; this version posted September 19, 2021. The copyright holder for this preprint (which was not certified by peer review) is the author/funder, who has granted bioRxiv a license to display the preprint in perpetuity. It is made available under aCC-BY 4.0 International license.

Surveys of the structure and composition of microbial communities are typically performed by PCR amplification and sequencing of a fragment of the small subunit of

81 the rRNA gene from an environmental sample (rRNA gene metabarcoding). The

82 fraction of the obtained sequencing reads corresponding to a given taxon is then

83 used as a proxy for its relative abundance. Most studies have so far focused on

84 taxonomically informative fragments of the hypervariable regions of the $16 \mathrm{~S}$ 85 (prokaryote and chloroplast) or 18S (eukaryotic nuclear) rRNA genes that are by far 86 the most represented in reference databases (Guillou et al., 2013; Pawlowski et al., 87 2012; Quast et al., 2013). These markers are occasionally targeted in both DNA and 88 RNA to exclude inactive microbes and as proxies of metabolic activities (Campbell, 89 Yu, Heidelberg, \& Kirchman, 2011; Logares et al., 2012), but more recent studies have indicated severe limitations of this concept and only mRNA can be considered as an indicator of the metabolic state (Blazewicz, Barnard, Daly, \& Firestone, 2013).

Although rRNA gene metabarcoding is widely used, it has multiple limitations (in addition to the error sources during DNA extraction or sequencing that also affect other molecular methods). Firstly, PCR amplification bias due to mismatches of universal primers on the target sites of certain taxa can generate differences between the observed and the genuine relative read abundances as large as 10-fold, either

97 when using the 16S (Parada, Needham, \& Fuhrman, 2016; Polz \& Cavanaugh, 1998; Wear, Wilbanks, Nelson, \& Carlson, 2018) or 18S rRNA gene markers (Bradley, the detection of these marker genes in metagenomes (Liu, Lozupone, Hamady, Bushman, \& Knight, 2007; Logares et al., 2014; Obiol et al., 2020). 
bioRxiv preprint doi: https://doi.org/10.1101/2021.05.28.446125; this version posted September 19, 2021. The copyright holder for this preprint (which was not certified by peer review) is the author/funder, who has granted bioRxiv a license to display the preprint in perpetuity. It is made available under aCC-BY 4.0 International license.

Secondly, the copy-number of these marker genes varies greatly among species. While bacterial genomes contain between one and fifteen copies of the $16 \mathrm{~S}$ rRNA gene (Acinas, Marcelino, Klepac-Ceraj, \& Polz, 2004; Kembel, Wu, Eisen, \& Green, 2012; Větrovský \& Baldrian, 2013), protists can differ by $>5$ orders of magnitude in their $18 \mathrm{~S}$ rRNA gene copy numbers, from 33,000 in dinoflagellates to one in small chlorophytes (de Vargas et al., 2015; Godhe et al., 2008; Mäki, Salmi, Mikkonen, Kremp, \& Tiirola, 2017; Zhu, Massana, Not, Marie, \& Vaulot, 2005). Due to a positive association between rRNA gene copy number and cell size, it was proposed that the rRNA gene metabarcoding reads reflect the relative biovolume proportion for a given taxon. Biovolume is a proxy of biomass, which is a relevant variable for studies of energy and matter fluxes such as food web structures and biogeochemical cycles. However, there is still little consensus for the use of rRNA gene as a biovolume estimator due to the poor correlations reported in many studies (Lamb et al., 2019; Lavrinienko, Jernfors, Koskimäki, Pirttilä, \& Watts, 2021; Santoferrara, 2019; van der Loos \& Nijland, 2021). Instead, there are attempts to infer relative cell abundances from rRNA gene metabarcoding by correcting the copy number variation. Although the copy number remains unknown for most microbial species, its assessment in different organisms could lead to the establishment of correction factors by assuming that the copy number is phylogenetically conserved. These approaches were applied for 16S rRNA gene in bacteria, but their accuracy is limited for taxa with no close representatives in reference phylogenies (Kembel et al., 2012; Louca, Doebeli, \& Parfrey, 2018; Starke, Pylro, \& Morais, 2020). In protists, this correction is even more challenging due to intraspecies variation in $18 \mathrm{~S}$ rRNA gene copy number. For example, it varies almost 10-fold among 14 different strains 
126 of the haptophyte Emiliana huxleyi (Gong and Marchetti 2019). In addition, there are 127 major difficulties for generating a comprehensive database of 18S rRNA copy 128 numbers (Gong \& Marchetti, 2019).

Finally, functional traits such as photosynthesis cannot be inferred solely from rRNA genes or other housekeeping markers, whereby their knowledge is limited to a restricted number of taxa known from experts and the literature. Indeed, while photosynthesis occurs in almost all cyanobacteria (except a few symbiotic lineages that have lost it (Nakayama et al., 2014; Thompson et al., 2012)), it is not necessarily conserved within protist taxa, such as dinoflagellates - of which only around half of known species are photosynthetic (Dorrell \& Smith, 2011; Saldarriaga, Taylor, Keeling, \& Cavalier-Smith, 2001) - , chrysophytes (Dorrell et al., 2019; Dorrell \& Smith, 2011) and apicomplexa (Moore et al., 2008). This is an important issue because we still do not know how extended among related lineages are the independent events of chloroplast gains and losses or the extent of loss of photosynthesis with retention of the plastids. Thus, it is not possible to annotate the photosynthesis trait to those sequences whose taxonomic affiliation is, for example, "unknown dinoflagellate". cyanobacteria and eukaryotic phytoplankton with two different rRNA marker genes. This can be still attempted by targeting the plastidial and cyanobacterial versions of the 16S rRNA gene (Nicholas J. Fuller et al., 2006; N. J. Fuller et al., 2006; Kirkham et al., 2011, 2013; Lepère, Vaulot, \& Scanlan, 2009; McDonald, Sarno, Scanlan, \& Zingone, 2007; Shi, Lepère, Scanlan, \& Vaulot, 2011). However, dinoflagellates and chromerids are not represented in these surveys because their plastidial 16S rRNA 
150 genes are extremely divergent (Green, 2011), and this approach can still capture non-photosynthetic plastids and kleptoplastids (functional plastids temporarily retained from ingested algal prey). Plastid-encoded markers directly involved in photosynthesis have also been used, such as $p s b A$ and $r b c L$ (Man-Aharonovich et al., 2010a; Paul, Alfreider, \& Wawrik, 2000; Zeidner, Preston, Delong, Massana, Post, Scanlan, \& Beja, 2003). The $p s b A$ gene encodes the D1 protein of photosystem II and is also found in cyanophages (viruses) and the used primers target essentially the cyanobacterial and cyanophage sequences (Adriaenssens \& Cowan, 2014). The rbcL gene encodes the large subunit of the ribulose-I,5diphosphate carboxylase/oxygenase (RuBisCO). There are multiple rbcL types, even in non-photosynthetic organisms, and the gene location varies: form I is plastid encoded in plants and most photosynthetic protists (and is present in cyanobacteria) while form II is nuclear-encoded in peridinin dinoflagellates and chromerids (and is also present in proteobacteria) (Tabita, Hanson, Satagopan, Witte, \& Kreel, 2008). The different $r b c L$ variants thus prevent its use for covering the whole phytoplankton community.

Plastid-encoded genes (16S rRNA, $p s b A, r b c L$ ) are affected by copy number variability among taxa not only at the level of gene copies (for example, four $16 \mathrm{~S}$ rRNA gene copies in the plastid genome of the euglenophyte Euglena gracilis and six in the prasinophyte Pedinomonas minor (Decelle et al., 2015)), but also at the level of plastid genomes per plastid, and plastids per cell. The plastid number per cell varies

171 from one or a few in most microalgal species to more than 100 in many centric 172 diatoms (Decelle et al., 2015). In addition, this varies according to biotic interactions, e.g., the haptophyte Phaeocystis has two plastids in a free-living stage but increases 
174 up to 30 when present as an endosymbiont of radiolarians (Decelle et al., 2019).

175 Photosynthetic eukaryotes typically maintain 50-100 plastid genome copies per

176 plastid, but there is a continuous increase throughout development and during cell

177 cycle progression (Armbrust \& Virginia Armbrust, 1998; Coleman \& Nerozzi, 1999;

178 Hiramatsu, Nakamura, Misumi, Kuroiwa, \& Nakamura, 2006; Koumandou \& Howe,

179 2007; Oldenburg \& Bendich, 2004). These limitations of plastid-encoded marker

180 genes can be circumvented by the use of photosynthetic nuclear-encoded genes,

181 which is still an unexplored approach.

In spite of the aforementioned biases, gene metabarcoding either based on

rRNA genes or on alternative marker genes such as $p s b A$ or $r b c L$ usually assume

that the relative abundance of the gene sequences is an accurate measure of the relative abundance of the organisms containing those sequences. However, this assumption can lead to misleading inferences about microbial community structure and diversity, including relative abundance distributions, estimates of the abundance of different taxa, and overall measures of community diversity and similarity (Bachy, Dolan, López-García, Deschamps, \& Moreira, 2013; Egge et al., 2013; Kembel et al., 2012; Mäki et al., 2017; Medinger et al., 2010; Pinto \& Raskin, 2012). For example, less than $30 \%$ of the variance in true organismal abundance is explained by observed prokaryotic 16S rRNA gene abundance in some simulation analyses (Kembel et al., 2012). In addition, comparative studies between morphological and molecular approaches in environmental samples or in mock communities revealed discrepancies up to several orders of magnitude among protist taxa with regard to their relative abundances (Bachy et al., 2013; Egge et al., 2013; Mäki et al., 2017; 
198 Esling, 2016). Most of these studies focused on the biases generated by primers and copy-number variations, but not on uncertainties in assigning photosynthetic potential

(e.g., differentiating between functionally photosynthetic and secondarily non201 photosynthetic species).

We deemed it important to find more accurate alternative procedures to the most widely-used molecular approaches to make reliable estimations of species abundance, an important measure for inferring community assembly processes. We propose to target nuclear-encoded single-copy core photosynthetic genes obtained from metagenomes to circumvent these limitations: the method is PCR-free, and the genes are present in both prokaryotes and eukaryotes, in one copy per genome. We focused on the $p s b O$ gene, which encodes the manganese-stabilising polypeptide of

209 the photosystem II oxygen evolving complex, and is essential for photosynthetic 210 activity and has the additional advantage of lacking any non-photosynthetic 211 homologs. We applied and validated this new strategy with the Tara Oceans datasets

212 (Table I). We quantified the biases in taxon abundance estimates using rRNA gene 213 markers as compared to optical approaches (flow cytometry, microscopy), and we 214 compared these patterns with those obtained by our proposed method. We also 215 searched for $p s b O$ within metatranscriptomes to analyse its potential use as a proxy 216 of photosynthetic activity and/or biovolume (due to the higher transcript level 217 requirements in larger cells). Besides finding a more relevant marker gene for 218 phytoplankton, we also propose its combination with single-copy housekeeping 219 genes (e.g., recA for bacteria and genes encoding ribosomal proteins in eukaryotes) 220 to estimate the fraction of photosynthetic members in the whole community or in a 221 given taxon. In this context, we also quantified the unknowns in the functional 
222 assignation of photosynthetic capacity based on the 18S rRNA gene. Finally, we

223 show how the approach improves measures of microbial community diversity,

224 structure, and composition as compared to rRNA gene metabarcoding.

\section{Materials and Methods}

\section{Search for phytoplankton marker genes}

To estimate cell-based relative abundances of the major marine phytoplankton

groups, we searched for genes present in all photosynthetic organisms (both

prokaryotes and eukaryotes) and with low copy-number variability among taxa. To

fulfil the latter requirement, we first excluded the plastid-encoded genes to avoid the

variations in number of chloroplasts per cell and in number of chloroplast genomes

per organelle. We did this by retrieving sequences from the KEGG (M. Kanehisa,

2000) database that are assigned to the photosynthetic electron transport chain, the

Calvin Cycle and chlorophyll biosynthesis to be used as queries for sequence

237 similarity searches against $>4,100$ plastid genomes available at NCBI

238 (https://www.ncbi.nlm.nih.gov/genome/organelle/). For this, BLAST version 2.2.31

239 ("tBLASTn" program) searches were conducted with an e-value cutoff of 1e-20

240 (Camacho et al., 2009). To retain only core photosynthetic genes, i.e., those present

241 in all phototrophs, we then made an equivalent BLAST search against cyanobacterial

242 and eukaryotic nuclear genomes from the IMG (Chen et al., 2019) and PhycoCosm

243 (Grigoriev et al., 2021) databases and from the polyA-derived transcriptomes of the

244 Marine Microbial Eukaryote Transcriptome Sequencing Project (MMETSP) (Keeling

245 et al., 2014). To minimize false-negative cases, only completely sequenced genomes 
246 were considered for establishing the gene absence. This survey was also used for

247 determining gene copy number variation.

This survey resulted in a list of five genes that are core, nuclear-encoded and present in low-copy numbers (Table II). For selecting a gene marker of phytoplankton among them, we carried out a deeper sequence analysis to detect nonphotosynthetic homologs and to see if the phylogeny reflects the evolutionary history of cyanobacteria and endosymbiosis. We first performed a sequence similarity search using HMMer version 3.2.1 with gathering threshold option (http://hmmer.org/) for the corresponding Pfam domain against the translated sequenced genomes and transcriptomes from PhycoCosm and MMETSP as well as in the whole IMG database (including viruses, archaea, bacteria and non-photosynthetic eukaryotes). The Pfams used in the search were: MSP (PF01716) for PsbO, Rieske (PF00355) for PetC, PRK (PF00485) for phosphoribulokinase, UbiA (PF01040) for chlorophyll-a synthase, and NAD_binding_1 (PF00175) for ferredoxin:NADP ${ }^{+}$reductase. CDHIT version 4.6.4 (W. Li \& Godzik, 2006) was used at a $80 \%$ identity cut-off to reduce redundancy. These sequences were used for building a protein similarity network using EFI-EST tool (Zallot, Oberg, \& Gerlt, 2019) and Cytoscape visualization (Shannon et al., 2003), and BlastKOALA with default parameters for functional annotation (Minoru Kanehisa, Sato, \& Morishima, 2016). These analyses led us to focus on $p s b O$ as a gene marker for phytoplankton, for which we did a deeper analysis by building its phylogeny in the following way. Protein sequences were aligned with MAFFT version 6 using the G-INS-I strategy (Katoh \& Toh, 2008).

268 Phylogenetic trees were generated with PhyML version 3.0 using the LG substitution 
270 al., 2010). The starting tree was a BIONJ tree and the type of tree improvement was

271 subtree pruning and regrafting. Branch support was calculated using the approximate

272 likelihood ratio test (aLRT) with a Shimodaira-Hasegawa-like (SH-like) procedure.

Tara Oceans expeditions between 2009 and 2013 performed a worldwide

276 sampling of plankton in the upper layers of the ocean (Sunagawa et al., 2020). To

277 capture the whole size spectrum of plankton, a combination of filter membranes with different pore sizes (size-fractionation) was used to separate organisms by body size (Pesant et al. 2015). There is an inverse logarithmic relationship between plankton size and abundance (Belgrano, Allen, Enquist, \& Gillooly, 2002; Pesant et al., 2015), so small size fractions represent the numerically dominant organisms in terms of cell abundance (albeit not necessarily in terms of total biovolume or biomass). Thus, the protocols consisted in the filtering of higher seawater volumes for the larger size fractions (Pesant et al., 2015). Five major organismal size fractions were collected: picoplankton (0.2-3 $\mu \mathrm{m}$ size fraction), piconanoplankton (0.8-5 $\mu \mathrm{m}$ size fraction), nanoplankton (5-20 $\mu \mathrm{m}$ size fraction), microplankton (20 to $180 \mu \mathrm{m})$, and mesoplankton (180 to $2000 \mu \mathrm{m})$. These plankton samples were leveraged to generate different molecular and optical datasets that were analysed in the current

289 work (Table I). We exclusively used the datasets corresponding to surface samples 290 (5 m depth). 
To use the metagenomic and metatranscriptomic read abundances of $p s b O$ as

a proxy of phytoplankton relative cell abundance and 'activity', respectively, we carried out a HMMer search as stated in the previous section against the two Tara (OM-RGC.v2) covering prokaryotic and eukaryotic picoplankton $(<3 \mu \mathrm{m})$, and the

Marine Atlas of Tara Oceans Unigenes version 1 (MATOU.v1) covering eukaryotic plankton ranging from 0.8 to $2000 \mu \mathrm{m}$ (Table I). The metagenomic and metatranscriptomic reads are already mapped onto both catalogs, thus we retrieved these values for those sequences obtained by our HMMer search. For the taxonomic assignment of $p s b O$ unigenes, we performed a phylogenetic placement of the translated sequences on the PsbO protein reference phylogenetic tree described in the previous section. For parallelization of the task, a set of 50 unigenes were translated and the PsbO specific Pfam PF01716 region was retrieved for the analysis in the following way. First, they were aligned against the reference alignment described in the previous section using the option --add of MAFFT version 6 with the G-INS-I strategy (Katoh and Toh 2008). The resulting alignment was used for building a phylogeny with PhyML version 3.0 as described above (Guindon et al., 2010). The sequences were classified using the APE library in R (Paradis \& Schliep, 2019) according to their grouping in monophyletic branches of statistical support $>0.7$

311 with reference sequences of the same taxonomic group. metagenomes, the MATOU-v1 catalog only contains sequences assembled from 314 poly-A-tailed RNA (Alberti et al., 2017; Carradec et al., 2018), which biases against 
315 prokaryotic sequences. To determine the structure of the whole phytoplankton community (including both cyanobacteria and eukaryotic phytoplankton), we aligned

317 all the metagenomic reads from Tara Oceans to a curated database of $p s b O$ 318 sequences (described below; see also Table I). The analysis was carried out using 319 the bwa tool version 0.7.4 (H. Li \& Durbin, 2009) with the following parameters: 320 minReadSize $\quad 70 \quad$-identity $80 \quad$-alignment $80 \quad$-complexityPercent $75 \quad$ complexityNumber 30. Abundance values were expressed in rpkm (reads per kilobase covered per million of mapped reads).

In general, the rpkm values for the different taxa under study were converted to analysis the psbO rpkm values were normalized by those values form single-copy housekeeping genes: by bacterial recA (Sunagawa et al. 2013) to estimate the contribution of cyanobacteria in the bacterioplankton, or by the average abundance while the ribosomal proteins were recovered from the MATOU-v1 and OMRGC-v2 abundance tables.

We used two different datasets generated by Tara Oceans for "traditional" DNAbased methods: 16S rRNA gene miTags (size fraction 0.2-3 $\mu \mathrm{m}$ ) and 18S rRNA gene

337 (V9 region) metabarcoding (sizes fractions 0.8-5, 5,20, 20-180, 180-2000 $\mu \mathrm{m}$ ) (Table 
338 I). We extracted the relative abundances for the 726 Operational Taxonomic Units

339 (OTUs) assigned to picophytoplankton (cyanobacteria and chloroplasts) from the 16S

340 miTags and the 31,930 OTUs assigned to eukaryotic phytoplankton from the V9-18S

341 metabarcoding data. The read abundances were expressed as relative abundance

$342(\%)$ in relation to the picophytoplankton community for $16 \mathrm{~S}$ miTags, and in relation to

343 eukaryotic phytoplankton for V9-18S metabarcoding.

The assignations of the 16S and V9-18S rRNA sequences to phytoplankton

345 were based on literature and expert information and included photosynthetic

346 dinoflagellates and chrysophytes when their taxonomic resolution was sufficient to

347 match known photosynthetic lineages. A full description of the $18 \mathrm{~S}$ taxonomic

348 classification procedure is at http://taraoceans.sb-roscoff.fr/EukDiv/ and the last

349 version of the trait reference database used in the current work is available at https://

350 zenodo.org/record/3768510\#.YM4ny3UzbuE. In the case of $16 \mathrm{~S} \mathrm{miTags,}$ the

351 taxonomic assignment was improved by building a phylogenetic tree with the $16 \mathrm{~S}$

352 miTags sequences and a curated set of references from NCBI and MMETSP.

353 Sequences were aligned using MAFFT v7.0 (Katoh \& Standley, 2013) with --auto

354 setting option and then trimmed using trimal with the -gt 0.5 and $-g t 0.8$ settings, and

355 the resulted alignment was used for tree building using RAxML v8 (Stamatakis, 2014)

356 (100 bootstrap replicates, GTRCAT substitution model).

\section{Optical-based community data}

We also used quantitative optical data generated by Tara Oceans (Table I),

360 where cell abundance is assumed to be more accurate and less biased, and 
additional features such as biovolume can be determined. The datasets cover: flow cytometry for picoplankton, confocal microscopy for 5-20 $\mu \mathrm{m}$ size fraction, and light microscopy for 20-180 $\mu$ m size fraction.

Flow cytometry counts were determined on $1 \mathrm{ml}$ replicated seawater samples filtered through $200 \mu \mathrm{m}$ that were fixed with cold $25 \%$ glutaraldehyde (final concentration $0.125 \%$ ) and stored at $-80^{\circ} \mathrm{C}$ until analysis. Details about the procedure can be found in (Gasol \& Morán, 2015; Hingamp et al., 2013; Pierella Karlusich et al., 2021). The cell biovolume was calculated using the equation of (Calvo-Díaz \& Morán, 2006) on the bead-standardized side scatter of the populations and considering cells to be spherical.

Quantitative confocal microscopy was performed using environmental High

372 Content Fluorescence Microscopy (eHCFM) (Colin et al., 2017). Briefly, samples were fixed with $10 \%$ monomeric formaldehyde (1\% final concentration) buffered at $\mathrm{pH} 7.5$ and $500 \mu \mathrm{l}$ EM grade glutaraldehyde (0.25\% final concentration) and kept at 4 ${ }^{\circ} \mathrm{C}$ until analysis. Sample collection and preparation as well imaging acquisition is described in (Colin et al., 2017). The 5-20 $\mu \mathrm{m}$ size fraction has been classified at a coarse taxonomic level (with an estimated accuracy of $93.8 \%$ at the phylum or class level), into diatoms, dinoflagellates, haptophytes, and other/unclassified eukaryotic phytoplankton (Colin et al., 2017). We used the major and minor axis of every image to calculate their ellipsoidal equivalent biovolume. The $20-180 \mu \mathrm{m}$ size fraction is also available, but the curated taxonomic annotation is limited to symbiotic (Richelia, Calothrix) and colony-forming (Trichodesmium) nitrogen-fixing cyanobacteria

383 (Pierella Karlusich et al. 2021), which were also used in the current work. 
For light microscopy, three $\mathrm{ml}$ of each sample (from $20-180 \mu \mathrm{m}$ size fractions)

385

386

387

388

To be compared with the molecular data, the optical data were expressed as relative abundance (\%). In the case of flow cytometry, as \% over the total number of cells counted as picophytoplankton (Prochlocococcus + Synechococcus + eukaryotic picophytoplankton). In the case of confocal and optical microscopy, as \% over the total number of cells counted as eukaryotic phytoplankton.

\section{psbO database generation}

We compiled, curated and annotated a database of $>18,000$ unique $p s b O$ sequences covering cyanobacteria, photosynthetic protists, macroalgae and land plants (Figure S1). It includes sequences retrieved from IMG, NCBI, MMETSP and other sequenced genomes and transcriptomes from cultured isolates, as well as from the environmental sequence catalogs from Global Ocean Sampling (Rusch et al., 2007) and Tara Oceans (Carradec et al., 2018; Delmont et al., 2020, 2021; Salazar et al., 2019). The database can be downloaded from the EMBL-EBI repository BioStudies (www.ebi.ac.uk/biostudies) under accession S-BSST659. We expect to maintain it updated to facilitate its incorporation in molecular-based surveys. 
Graphical analyses were carried out in R language (http://www.r-project.org/) 408 using ggplot2 (Wickham, 2016) and treemaps were generated with treemap. Maps 409 were generated with borders function in ggplot2 and geom_point function for bubbles 410 or scatterpie package for pie charts (Yu, 2018). Spearman's rho correlation

411 coefficients and p-values were calculated using the cor.test function of the stats 412 package. Shannon diversity indexes were calculated using the vegan package 413 (Oksanen et al. 2020). Intra- and inter-specific genetic distances were calculated in 414 MEGAX (Kumar, Stecher, Li, Knyaz, \& Tamura, 2018) using the Maximum 415 Composite Likelihood model.

\section{Results}

We first analysed transcriptomes and nuclear and plastid genomes derived from

421 cultured strains to inventory photosynthetic genes in relation to their genome location

422 (nuclear- vs plastid-encoded) and taxonomic prevalence (core vs non-core, i.e., 423 present in all phototrophs or not) (see Methods; Figure 1A). Among the plastid424 encoded genes, we identified phytoplankton marker genes previously used in 425 environmental surveys, such as psbA (Man-Aharonovich et al., 2010b; Zeidner, 426 Preston, Delong, Massana, Post, Scanlan, \& Béjà, 2003), rbcL (nuclear encoded in 427 dinoflagellates containing peridinin) (Paul et al., 2000) and petB (Farrant et al., 2016) 428 (Figure 1A). 
Among the nuclear-encoded genes, we retrieved some which are non-core,

430 such as those encoding flavodoxin $(f l d)$ and plastocyanin (petE), but also five core

431 genes (Figure 1A; Table II). These five genes are present in low-copy number and

432 encode components of the photosynthetic electron transport chain ( $p s b O$, petC and

433 petH), the carbon fixation pathway (prk) or chlorophyll biosynthesis (ch/G) (Table II).

434 The absence of non-photosynthetic homologs is a unique characteristic of $p s b O$ 435 (Table II and Figures S2-S6), reflecting its essential role in photosynthetic oxygen 436 evolution, and a clear advantage for its use as a marker gene for phytoplankton.

437 Previous studies of secondarily non-photosynthetic eukaryotes have marked its 438 presence or absence as being an effectively universal predictor of photosynthetic 439 potential (Dorrell et al., 2019). Its phylogeny additionally reflects the evolutionary 440 history of endosymbiosis (Figure 1B; Pierella Karlusich et al. 2015), with few or no 441 post-endosymbiotic horizontal replacements known, so we focused on this gene for 442 the analysis of environmental samples.

Although no global barcoding gap (i.e., a distance threshold set for all species)

444 was detected when checking intra- vs inter-specific divergences for eukaryotic 445 phytoplankton based on $p s b O$, it was neither observed with the $\mathrm{V} 9$ region of the 446 traditional marker $18 \mathrm{~S}$ rRNA gene (Figure S7). This absence does not necessarily 447 preclude specimen identification, which relies upon the presence of a 'local' 448 barcoding gap (i.e., a query sequence being closer to a conspecific sequence than a 449 different species), rather than the 'global' barcoding gap (i.e., a distance threshold set 450 for all species) that is required for species discovery (Collins \& Cruickshank, 2013). 
453 Methods and Table I). A total of 307 distinct sequences were identified in OM-

454 RGC.v2 (202 from Prochlorococcus, 79 from Synechoccocus and 26 from eukaryotic

455 picophytoplankton), with an average length for the conserved coding region of 473

456 base pairs and a range between 94 and 733 base pairs. A total of 10,646 sequences

457 from eukaryotic phytoplankton were retrieved from MATOU.v1, with an average

458 length for the conserved coding region of 385 base pairs and a range between 66 459 and 784 base pairs. The analyses of the metagenomic and metatranscriptomic read abundances of these sequences are presented in the following sections. differences with the traditional molecular approaches

Oceans samples by focusing on the traditional marker genes coding for the small subunit of rRNA (16S for prokaryotes and plastids, 18S for eukaryotes) in the different size-fractionated samples. We focused exclusively on the phytoplankton signal of these datasets, despite the uncertainties in assigning photosynthesis capacity in groups such as dinoflagellates and chrysophytes (this is evaluated in one 470 of the next sections).

472 picocyanobacteria Prochlorococcus and Synechococcus were prevalent, while $\sim 60 \%$

473 of the average read abundance was attributed to eukaryotic photosynthetic taxa such

474 as haptophytes, chlorophytes, pelagophytes, dictyochophytes, chrysophytes, 475 cryptophytes and diatoms (Figure 2A). In the larger size fractions, based on the V9476185 region metabarcoding reads, diatoms and dinoflagellates were the most frequent 
477 among eukaryotic phototrophs, especially in the 5-20 $\mu \mathrm{m}$ and $20-180 \mu \mathrm{m}$ size 478 fractions (Figure 2B). In the 180-2000 $\mu \mathrm{m}$ fraction, diatoms and dinoflagellates were 479 still abundant, due to the presence of large diameter cells (Tripos, Pyrocystis), chain480 forming (e.g., Chaetoceros, Fragilaria) or epizoic (e.g., Pseudohimantidium) species, 481 without discarding that smaller species may be retained in samples of this size 482 fraction due to net clogging or within herbivorous guts and faecal pellets. Relative 483 abundance in the smaller $0.8-5 \mu \mathrm{m}$ size fraction was much more homogeneously 484 distributed between the different groups.

For psbO-based methods, we found that metagenomic and metatranscriptomic 486 reads from Synechococcus, Prochlorococcus, pelagophytes, chlorophytes and 487 haptophytes to be dominant among picophytoplankton $(0.2-3 \mu \mathrm{m})$, along with 488 dictyochophytes and chrysophytes (Figure 2A). In the larger size fractions, 489 haptophytes, chlorophytes and pelagophytes clearly dominated the eukaryotic 490 phytoplankton in the 0.8-5 $\mu \mathrm{m}$ size fraction, whereas diatoms and dinoflagellates 491 were more abundant in the three larger size ranges $(5-20 \mu \mathrm{m}, 20-180 \mu \mathrm{m}, 180-2000$ $492 \mu \mathrm{m})$, although haptophytes, chlorophytes and pelagophytes were also detected in 493 large quantities (Figure 2B). The potential cyanobacteria present in these large size 494 fractions are presented later in another section due to the need to bypass the 495 sequences assembled from poly-A-tailed RNA for analysing prokaryotes (see 496 Methods and Table I).

We noted some differences in $p s b O$ read counts between metagenomic and 498 metatranscriptomic datasets. In the case of picophytoplankton, Prochlorococcus was enriched in metagenomes in comparison to (total RNA) metatranscriptomes (likely due to low transcript content needs for their low cell volume), the opposite occurred 
501 for pelagophytes and haptophytes, whereas no major changes were observed for Synechococcus and chlorophytes (Figures 2A and S8A). In the case of larger photosynthetic protists, dinoflagellates were highly abundant at the (polyA) transcript level in comparison to gene abundance (probably they blanket overtranscribe genes as they predominantly perform post-transcriptional gene regulation (Roy, Jagus, and Morse 2018; Cohen et al. 2021)), the opposite was observed for pelagophytes and chlorophytes (in this latter taxon only in the $20-180$ and $180-2000 \mu \mathrm{m}$ size ranges), whereas no major shifts were apparent for diatoms and haptophytes (Figures 2B and S8B).

The taxonomic abundance patterns based on psbO showed some differences

511 with those from $16 \mathrm{~S}$ miTags of $0.2-3 \mu \mathrm{m}$ size fraction, but exhibited remarkable 512 differences with those based on V9-18S metabarcoding of the large size fractions 513 (Figures 2A-B and S9). When compared with the 16S miTags, no major changes 514 were detected for Prochlorococcus, whereas the average psbO metagenomic contribution increased for Synechococcus (from $\sim 8 \%$ to $\sim 14 \%$ ), at the expense of decreasing eukaryotic picoplankton contribution (from $57 \%$ to $\sim 50 \%$ ), which is

517 expected due to the fact that the 16S rRNA is a plastid-encoded gene in eukaryotes.

518 When we compared psbO with V9-18S metabarcoding, the differences were very 519 significant. In the $0.8-5 \mu \mathrm{m}$ size fraction, diatoms and dinoflagellates accounted for just $\sim 6 \%$ of average $p s b O$ metagenomic read abundance but for $\sim 44 \%$ of $18 S$ reads

521 assigned to phytoplankton. In the three larger size ranges (5-20 $\mu \mathrm{m}, 20-180 \mu \mathrm{m}$ and $522180-2000 \mu \mathrm{m})$, they accounted for $37-47 \%$ of average $p s b O$ metagenomic read 523 abundance, but for $>90 \%$ of average $18 \mathrm{~S}$ read abundance. The $18 \mathrm{~S}$ read abundance 524 was extremely low for haptophytes, chlorophytes and pelagophytes in these three 
525 size fractions ( $<7 \%$ average $18 \mathrm{~S}$ read abundance). When we compared the 526 metatranscriptomic profile, it was more similar to the profile obtained with 527 metagenomes than to that obtained with V9-18S metabarcoding (Figure 2B).

To assess the accuracy of the psbO gene for determining phytoplankton cell

532 relative abundances, we carried out comparative analyses with imaging datasets. For

533 the 0.2-3 $\mu \mathrm{m}$ size fraction, we compared relative abundances based on $16 \mathrm{~S}$ and

$534 p s b \mathrm{O}$ counts with those inferred from flow cytometry (Figure 2C). Both genes were

535 found to correlate well with flow cytometry. Although the correlations for eukaryotic 536 picophytoplankton were strong (Spearman's rho=0.64-0.71, p-value $<<<0.001$ ), the 537 relationships were not linear and picoeukaryotes appeared at much higher relative 538 abundances in metagenomes than in flow cytometry. This is consistent with the fact 539 that flow cytometry can count cells of up to 10-20 $\mu \mathrm{m}$ diameter and was performed on 540 seawater aliquots pre-filtered through a $200-\mu \mathrm{m}$ mesh (see Methods), whereas DNA 541 isolation of picoplankton was carried out on seawater volumes mainly filtered through $5423-\mu \mathrm{m}$ pore sizes. When we discarded eukaryotes to focus only on the ratio Synechococcus / (Synechococcus + Prochlorococcus) (Figure S10), flow cytometry 544 data shows a linear relashiopship with psbO metagenomic reads, while $16 \mathrm{~S}$ miTags 545 reads underestimated Synechococcus and the opposite occurred for psbO 546 metatranscriptomic reads. In addition, the highest correlation with flow cytometry data 547 occurred with the psbO metagenomic counts (Spearman's rho $=0.92,0.90$ and 0.75 , 
$548 \mathrm{p} \ll<0.001$, for $p s b O$ metagenomic reads, $p s b O$ metatranscriptomic reads and $16 \mathrm{~S}$

549 miTags, respectively).

For the 5-20 $\mu \mathrm{m}$ size fraction, the relative abundance of eukaryotic photosynthetic organisms was determined by cell counts using high-throughput confocal microscopy. We compared these results with the proportions based on V9$18 S$ metabarcoding and $p s b O$ metagenomic reads (Figure 2D). The metabarcoding data for dinoflagellates and diatoms were in good agreement with the microscopy but it clearly underestimated the relative abundance of haptophytes and other eukaryotic phytoplankton. Regarding $p s b O$, the metagenomic relative abundances were in stronger agreement with the microscopy counts for the four defined phytoplankton groups (Figure 2D). Therefore, in the 5-20 $\mu \mathrm{m}$ size fraction, diatoms and dinoflagellates displayed robust patterns of relative abundance using either V9-18S metabarcoding or psbO metagenomic counts, while haptophytes and the other groups were better described by psbO.

In the 20-180 $\mu \mathrm{m}$ size fraction, the relative abundance of eukaryotic

563 phytoplankton was determined by light microscopy. Again, the metabarcoding data

564 for dinoflagellates and diatoms were in good agreement with the microscopy data but clearly underestimated the relative abundance of haptophytes and other eukaryotic phytoplankton groups (Figure 2D). The metagenomic read relative abundances of psbO were in stronger agreement with the microscopy counts for the four defined phytoplankton groups, although the correlation with haptophytes was weaker (Figure 2D). Therefore, in the $20-180 \mu \mathrm{m}$ size fraction, diatoms and dinoflagellates displayed robust patterns of relative abundance using either V9-18S metabarcoding or $p s b O$ 
571 metagenomic counts, while haptophytes were weakly described by both methods

572 and the other groups were much better described by $p s b O$.

We also compared the relative abundances based on optical methods against

574 those based on psbO metatranscriptomic reads, and in general we observed good

575

576

$577 \quad($ e.g

578

579

580

Comparison with optical-based biovolume suggests that neither psbO nor rRNA genes are good proxies for estimating relative proportion of biovolume

We also compared the relative read abundances of the different marker genes against the proportional biovolumes for each taxon (Figure 3). Although the copy number of rRNA marker genes was previously proposed as a proxy of cell biovolume, the correlation of biovolume against rRNA gene relative abundances was not stronger than those against $p s b O$ (Figures 3 and S12). The relative read abundances for Prochlorococcus and eukaryotic picophytoplankton based either on 16S rRNA gene or psbO were higher than their proportional biovolumes in the same samples, while the opposite was the case for Synechococcus. In the 5-20 $\mu \mathrm{m}$ size fraction, the biovolume proportion for haptophytes was clearly described by their psbO relative abundance, while their $\mathrm{V} 9-18 \mathrm{~S}$ rRNA gene reads were very low in 
594 relation to their biovolume. Both V9-18S rRNA gene and $p s b O$ reads were correlated

595 with the relative biovolume for diatoms and dinoflagellates, but for V9-18S rRNA for the reads were higher in relation to their biovolume. As the biovolume of other taxa was very low, their proportion of $p s b O$ reads was much higher than the corresponding biovolume fraction, whereas there was no correlation between V9-18S and biovolume.

Diversity analysis: Shannon-index is robust to the biases introduced by the index, a diversity index that relates monotonically to species richness but differs in

607 that it downweights rare species, whose numbers are highly sensitive to 608 undersampling and molecular artefacts (Calderón-Sanou, Münkemüller, Boyer, 609 Zinger, \& Thuiller, 2020). We found a strong correlation between Shannon values for eukaryotic phytoplankton defined either by $18 \mathrm{~S}$ rRNA gene metabarcoding or by

611 psbO metagenomics or metatranscriptomics (Figure 4). This is in agreement with 612 previous reports showing no major effects of $16 \mathrm{~S}$ rRNA gene copy number variation 613 on the Shannon index of bacterial communities (Ibarbalz et al., 2019; Milanese et al., 614 2019). These results illustrate that not all subsequent analyses are affected by the biases introduced by traditional molecular methods. 
To evaluate the uncertainties when inferring the photosynthesis trait using the taxonomy obtained from a non-photosynthetic marker gene, we analysed the $18 \mathrm{~S}$ V9 OTUs assigned to dinoflagellates and found that most of their reads cannot be reliably classified as corresponding or not to a photosynthetic taxon (Figure 5A), especially for those OTUs whose taxonomic affiliation is "unknown dinoflagellate" (Figure S13). The uncertainty was especially significant in the $0.8-5 \mu \mathrm{m}$ size fraction, where on average the $\sim 80 \%$ of the total dinoflagellate read abundance remained unclassified (Figures 5A and S13).

Therefore, besides finding a more relevant marker gene for phytoplankton, we also propose combining it with established single-copy housekeeping genes (i.e., recA for bacteria (Sunagawa et al., 2013) and genes encoding ribosomal proteins for eukaryotes (Carradec et al., 2018; Ciccarelli et al., 2006)), to estimate the fraction of photosynthetic members in a given community or within a specific clade. In the case of eukaryotes, a set of genes of interest for this aim are petC and its mitochondrial homologs (i.e., the nuclear-encoded genes for the Rieske subunits of the Cyt bc-type complexes from chloroplasts and mitochondria) (Table II and Figure S5). As an example, we analysed the distribution of phototrophy across size fractions among the eukaryotic groups under study. As expected, it did not reveal any differences for 638 diatoms, haptophytes, chlorophytes or pelagophytes (Figure S14), reflecting the 639 relative paucity of described secondarily non-photosynthetic members of these groups. Instead, for dinoflagellates we observed a significant proportion of nonphotosynthetic lineages in the $0.8-5$ size-fraction in comparison with the other sizes 
642 ranges, which were also shown by the V9-18S rRNA gene metabarcoding method

643 (Figures 5B, S13 and S14). However, whereas the metabarcoding data showed a

644 dramatic increase in phototrophs towards the larger size classes of dinoflagellates,

645 the metagenomic analysis showed similar levels between the three larger size

646 fractions $(5-20 \mu \mathrm{m}, 20-180 \mu \mathrm{m}, 180-2000 \mu \mathrm{m})$ (Figure 5B). These different patterns

647 between the two marker genes might be explained by differences in the unknown

648 trait assignment of the 18S rRNA gene barcodes and/or in the 18S rRNA gene copy

649 number (e.g., higher copy number in photosynthetic species in larger size fractions).

The approach suggested can be applied to unveil variation of phototrophs in whole plankton communities, including both bacteria and eukaryotes. In order to do so, we mapped the metagenomic reads against our comprehensive catalog of $p s b O$ sequences (Figure S1). The highest proportion of phytoplankton among eukaryotes was observed in the $0.8-5 \mu \mathrm{m}$ size fraction, followed by the $5-20 \mu \mathrm{m}$ size-fraction, while the lowest value was found in the 180-2000 $\mu \mathrm{m}$ size range (Figure $5 \mathrm{C}$ ), where copepods are prevalent (considered one of the most abundant animals on the planet). Surprisingly, the percentage of phototrophs among bacterioplankton did not vary across size fractions (10-15\% on average; see next section). In the $0.2-3 \mu \mathrm{m}$ size fraction, very similar values were detected by 165 miTags, but when comparing both molecular methods with flow cytometry, the psbO/recA ratio was better 
To further examine the distribution of both prokaryotic and eukaryotic phytoplankton across the whole size spectrum, we continued the analysis of the mapped metagenomic reads against our catalogue of $p s b O$ sequences (Figure S1). We observed a high abundance of cyanobacteria in the large size fractions in relation

671 to the eukaryotic phytoplankton (Figure 6A). The nitrogen-fixers Trichodesmium and

672 Richelia/Calothrix were found principally in the 20-180 and 180-2000 $\mu \mathrm{m}$ size

673 fractions (Figure 6A), which is expected as the former forms filaments and colonies

674 while the second group are symbionts of certain diatoms (Figures 7B-D). These 675 genera were recently quantified in the high-throughput confocal microscopy dataset 676 from the 20-180 $\mu \mathrm{m}$ size fraction (Pierella Karlusich et al., 2021). We therefore 677 checked the correlations of these data with the $p s b O$ determinations and found them 678 to be very strongly related (Figure 6G).

To our surprise, we also detected a high abundance of both Prochlorococcus and, in particular, Synechococcus, in the large size fractions (Figure 6A) across multiple and geographically distinct basins of the tropical and subtropical regions of the world's ocean (Figure 7$)$. Picocyanobacteria have small cell diameters $(<1 \mu \mathrm{m})$, and therefore should readily pass through the filters with pore sizes of 5,20 or 180

$684 \mu \mathrm{m}$. Although smaller cells can get caught on larger filters, their abundance should be 685 limited and hence not responsible for the values observed. The reason why a 686 substantial fraction of picocyanobacteria were found in the largest size fractions may 687 be colony formation, symbiosis, attachment to particles, or their grazing by protists, 688 copepods and/or suspension feeders. We examined these possibilities by looking at 
689 the Tara Oceans confocal microscopy dataset, and found many microscopy images 690 evidencing colony formation and symbiosis in the $20-180 \mu \mathrm{m}$ size fraction (Figure 6E-

$691 \mathrm{~F})$. This is in agreement with the mapping of the Tara Oceans metagenomes against 692 a recently sequenced single cell genome of a Synechococcus living as a 693 dinoflagellate symbiont (Nakayama et al., 2019). In addition, there are reports of 694 picocyanobacterial symbionts among isolates of planktonic foraminifers, radiolarians, 695 tintinnids, and dinoflagellates (Bird et al., 2017; Foster, Collier, \& Carpenter, 2006; 696 Kim, Choi, \& Park, 2021; Yuasa, Horiguchi, Mayama, Matsuoka, \& Takahashi, 2012) 697 and picocyanobacterial colonies were observed in a regional study based on optical 698 methods (Masquelier \& Vaulot, 2008) and in lab cultures (W. Deng, Cruz, \& Neuer, 699 2016; Wei Deng, Monks, \& Neuer, 2015).

These results suggest that we should move from the traditional view of Synechococcus/Prochlorococcus as being exclusively part of picoplankton communities, and instead we should consider them as part of a broader range of the plankton size spectrum (in a similar way as occurs with other small-celled phytoplankton such as the haptophyte Phaeocystis; (Beardall et al., 2009; Decelle et al., 2019)). However, it should be borne in mind that these results correspond to estimates of relative cell abundance, and thus the picture is very different when translated to biovolume, due to the large differences in cell size (Figure S16). All in all, our approach allows us to make trans-domain comparisons, which can reveal photosymbiosis and cell aggregates (Figure 6), and allows us to examine the biogeography of the entire phytoplankton community simultaneously (Figures 7, S16 711 and S17). 


\section{Discussion}

713 We searched for core photosynthetic, single-copy, nuclear genes in genomes

714 and transcriptomes of cultured phytoplankton strains for their use as marker genes.

715 Of the five resulting candidates, $p s b O$ emerged as the most suitable due to its lack of

716 non-photosynthetic homologs (but note that the other genes could be incorporated in

717 future studies by discarding non-photosynthetic homologs by phylogenetic and/or

718 sequence similarity methods). We applied this new approach by retrieving $p s b O$

719 sequences from the metagenomes generated by Tara Oceans, and successfully

720 validated it using the optical determinations from the same expedition.

We also quantified the biases of "traditional" molecular approaches as

compared to the optical methods. The $16 \mathrm{~S}$ miTags approach avoids PCR biases and

723 seems to be little affected by copy variability of the $16 \mathrm{~S}$ gene, the plastid genome

724 and the chloroplast, probably because only the $0.2-3$ size fraction was analysed in

725 the current work, where most picoplankton cells only have a single chloroplast. It 726 would be a future scope to analyse larger size fractions where abundant taxa have 727 multiple plastids (e.g., centric diatoms) or divergent $16 \mathrm{~S}$ genes difficult to align (e.g.,

728 dinoflagellates). When compared with $18 \mathrm{~S}$ metabarcoding data, our approach yields

729 lower abundances for diatoms and dinoflagellates at the expense of higher

730 abundances of haptophytes, chlorophytes and pelagophytes. These results were

731 remarkably consistent with those obtained by microscopy. To disentangle the effect

732 of PCR-bias versus copy number in the patterns of $18 \mathrm{~S}$ metabarcoding, the next step

733 will be to generate $18 \mathrm{~S}$ miTags from the analysed metagenomes. It is important to

734 take into account that not all analyses are affected by the biases introduced by

735 traditional molecular methods, as we showed for the Shannon index. 
While our work demonstrated that $p s b O$ reflects the relative cell abundance of

737 phytoplankton, some previous studies suggested that rRNA genes reflect the relative

738 biovolume of the corresponding taxa. However, there is still no clear consensus for

739 rRNA genes as proxies of biovolume. Here, we did not observe major differences

740 between rRNA gene or psbO when correlated against optical-based biovolumes.

In addition to correcting for the abovementioned biases, we revealed

742 unexpected ecological features missed by $18 \mathrm{~S}$ metabarcoding. For example, our

743 trans-domain comparison detected picocyanobacteria in high numbers in large size

744 fractions, which was supported by the observation of numerous images of

745 picocyanobacterial aggregates and endosymbionts in the Tara Oceans imaging

746 dataset. Moreover, when the analysis of metagenomes includes housekeeping

747 marker genes (in addition to photosynthetic genes), we observed small

748 dinoflagellates $(0.8-5 \mu \mathrm{m})$ to be mainly heterotrophic, while those in the larger size

749 communities ( $>5 \mu \mathrm{m})$ to be mainly photosynthetic.

750 In addition to metagenomes, we also analysed $p s b O$ in metatranscriptomes,

751 where dinoflagellates stood out from the rest due to their much higher $p s b O$

752 abundance ratio of mRNA abundance to gene copy number. It will be of interest to

753 analyse if this reflects higher 'photosynthetic activity' or if it is an effect of their

754 predominant post-transcriptional regulation (Cohen et al., 2021; Roy, Jagus, \&

755 Morse, 2018).)

The very deep sequencing of the Tara Oceans metagenomes (between $\sim 10^{8}$ and $\sim 10^{9}$ total reads per sample) allowed us to carry out taxonomic analysis based on a unique gene, in spite of dilution of the signal. As reduced DNA sequencing costs

759 are leading to the replacement of amplicon-based methods by metagenome 
760 sequencing, we expect the utility of our method to increase in future years. In the short term, a barcode approach using $p s b O$ primers is a promising cheap alternative, although it will be subject to PCR biases and affected by the presence of introns. restricted to some surveys (using plastid-encoded genes) (Farrant et al., 2016; Man765 Aharonovich et al., 2010a; Paul et al., 2000; Zeidner, Preston, Delong, Massana, Post, Scanlan, \& Beja, 2003). This is not the case for other functional groups, such

767 as nitrogen-fixers, which are studied by targeting a gene encoding a subunit of the 768 nitrogenase enzymatic complex (Zehr \& Paerl, 1998) and for which extensive 769 reference sequence databases are now available (https://www.jzehrlab.com; (Heller, 770 Tripp, Turk-Kubo, \& Zehr, 2014)). To facilitate the incorporation of psbO into future 771 molecular-based surveys, we have generated a database of $>18,000$ annotated 772 psbO sequences (https://www.ebi.ac.uk/biostudies/studies/S-BSST659; Figure S1). 773 We hope that the release of this data, and the establishment of $p s b O$ as a new 774 biomarker for quantifying species abundances, opens new perspectives for 775 molecular-based evaluations of phytoplankton communities.

777 relative cell abundance of the whole phytoplankton community. However, when 778 focusing on either eukaryotes or prokaryotes, Shannon index is robust enough to be 779 based on rRNA genes. Finally, the use of molecular markers (either psbO or rRNA 780 genes) as proxies of relative phytoplankton biovolume is not established. 


\section{Acknowledgments}

782

We would like to thank all colleagues from the Tara Oceans consortium as well as

783 the Tara Ocean Foundation for their inspirational vision. We also acknowledge

784 Quentin Carradec for his help with genes encoding ribosomal proteins. This project

785 has received funding from the European Research Council (ERC) under the

786 European Union's Horizon 2020 research and innovation programme (Diatomic;

787 grant agreement No. 835067). Additional funding is acknowledged from the FFEM -

788 French Facility for Global Environment (Fonds Français pour I'Environnement

789 Mondial), and the French Government "Investissements d'Avenir" Programmes

790 MEMO LIFE (Grant ANR-10-LABX-54), Université de Recherche Paris Sciences et

791 Lettres (PSL) (Grant ANR-1253 11-IDEX-0001-02), France Genomique (ANR-10792 INBS-09), and OCEANOMICS (Grant ANR-11-BTBR-0008). JJPK acknowledges 793 postdoctoral funding from the Fonds Français pour l'Environnement Mondial. RGD 794 acknowledges a CNRS Momentum Fellowship, awarded 2019-2021. This article is 795 contribution number *** of Tara Oceans.

\section{Author contributions}

797 JJPK and CB designed the project. JJPK conducted the study and performed the 798 primary data analysis and visualization. JJPK compiled the $p s b O$ gene reference catalog and EP performed the metagenomic mapping on it. RGD carried out the phylogenetic-based annotation of $16 \mathrm{~S}$ rRNA gene OTUs. FL, SC and CdV helped

801 with the confocal microscopy dataset, AZ and ES with the optical microscopy and 802 JMG and SGA with the flow cytometry. All authors helped interpret the data. JJPK 803 and $\mathrm{CB}$ wrote the paper with substantial input from all authors. 


\section{Data availability statement}

805

806

807

808

809

810

\section{References}

Acinas, S. G., Marcelino, L. A., Klepac-Ceraj, V., \& Polz, M. F. (2004). Divergence and Redundancy of $16 \mathrm{~S}$ rRNA Sequences in Genomes with Multiple rrn Operons. Journal of Bacteriology, Vol. 186, pp. 2629-2635. doi: 10.1128/jb.186.9.2629-2635.2004

Adriaenssens, E. M., \& Cowan, D. A. (2014). Using signature genes as tools to assess environmental viral ecology and diversity. Applied and Environmental Microbiology, 80(15), 4470-4480.

Alberti, A., Poulain, J., Engelen, S., Labadie, K., Romac, S., Ferrera, I., ... Wincker, P. (2017). Viral to metazoan marine plankton nucleotide sequences from the Tara Oceans expedition. Scientific Data, 4, 170093.

Armbrust, E. V., \& Virginia Armbrust, E. (1998). Uniparental inheritance of chloroplast genomes. The Molecular Biology of Chloroplasts and Mitochondria in Chlamydomonas, pp. 93-113. doi: 10.1007/0-306-48204-5_6

Bachy, C., Dolan, J. R., López-García, P., Deschamps, P., \& Moreira, D. (2013). Accuracy of protist diversity assessments: morphology compared with cloning and direct pyrosequencing of 18S rRNA genes and ITS regions using the conspicuous tintinnid ciliates as a case study. The ISME Journal, 7(2), 244-255.

Beardall, J., Allen, D., Bragg, J., Finkel, Z. V., Flynn, K. J., Quigg, A., ... Raven, J. A. (2009). Allometry and stoichiometry of unicellular, colonial and multicellular phytoplankton. The New Phytologist, 181(2), 295-309. 
829 Belgrano, A., Allen, A. P., Enquist, B. J., \& Gillooly, J. F. (2002). Allometric scaling of maximum population density: a common rule for marine phytoplankton and terrestrial plants. Ecology Letters, Vol. 5, pp. 611-613. doi: 10.1046/j.1461-0248.2002.00364.x

832 Bird, C., Darling, K. F., Russell, A. D., Davis, C. V., Fehrenbacher, J., Free, A., ... Ngwenya, B. T. (2017). Cyanobacterial endobionts within a major marine planktonic calcifier (Globigerina bulloides, Foraminifera) revealed by $16 \mathrm{~S}$ rRNA metabarcoding. Biogeosciences , 14(4), 901-920.

836 Blazewicz, S. J., Barnard, R. L., Daly, R. A., \& Firestone, M. K. (2013). Evaluating rRNA as an indicator of microbial activity in environmental communities: limitations and uses. The ISME Journal, 7(11), 2061-2068.

Bradley, I. M., Pinto, A. J., \& Guest, J. S. (2016). Design and Evaluation of Illumina MiSeqCompatible, $18 \mathrm{~S}$ rRNA Gene-Specific Primers for Improved Characterization of Mixed

843 Calderón-Sanou, I., Münkemüller, T., Boyer, F., Zinger, L., \& Thuiller, W. (2020). From environmental DNA sequences to ecological conclusions: How strong is the influence of methodological choices? Journal of Biogeography, 47(1), 193-206. of the southern Bay of Biscay. Aquatic Microbial Ecology: International Journal, 42, 159_ 174. rare bacteria in a coastal ocean. Proceedings of the National Academy of Sciences, Vol. 108, pp. 12776-12781. doi: 10.1073/pnas.1101405108

855 Carradec, Q., Pelletier, E., Da Silva, C., Alberti, A., Seeleuthner, Y., Blanc-Mathieu, R., ... 
Wincker, P. (2018). A global ocean atlas of eukaryotic genes. Nature Communications, 9(1), 373.

858 Chen, I.-M. A., Chu, K., Palaniappan, K., Pillay, M., Ratner, A., Huang, J., ... Kyrpides, N. C. (2019). IMG/M v.5.0: an integrated data management and comparative analysis system for microbial genomes and microbiomes. Nucleic Acids Research, 47(D1), D666-D677.

Ciccarelli, F. D., Doerks, T., von Mering, C., Creevey, C. J., Snel, B., \& Bork, P. (2006). $1283-1287$.

Cohen, N. R., Mcllvin, M. R., Moran, D. M., Held, N. A., Saunders, J. K., Hawco, N. J., ...

Coleman, A. W., \& Nerozzi, A. M. (1999). Temporal and Spatial Coordination of Cells with

871 Colin, S., Coelho, L. P., Sunagawa, S., Bowler, C., Karsenti, E., Bork, P., ... de Vargas, C. (2017). Quantitative 3D-imaging for cell biology and ecology of environmental microbial eukaryotes. eLife, 6. doi: 10.7554/eLife.26066

874 Collins, R. A., \& Cruickshank, R. H. (2013). The seven deadly sins of DNA barcoding. Molecular Ecology Resources, 13(6), 969-975.

876 Decelle, J., Romac, S., Stern, R. F., Bendif, E. M., Zingone, A., Audic, S., ... Christen, R. photosynthetic eukaryotes with curated taxonomy. Molecular Ecology Resources, Vol. 
883 Delmont, T. O., Gaia, M., Hinsinger, D. D., Fremont, P., Vanni, C., Fernandez Guerra, A., ... 884 Jaillon, O. (2020). Functional repertoire convergence of distantly related eukaryotic plankton lineages revealed by genome-resolved metagenomics. bioRxiv. doi. 10.1101/2020.10.15.341214

Delmont, T. O., Pierella Karlusich, J. J., Veseli, I., Fuessel, J., Murat Eren, A., Foster, R. A., ... Pelletier, E. (2021). Heterotrophic bacterial diazotrophs are more abundant than their cyanobacterial counterparts in metagenomes covering most of the sunlit ocean. bioRxiv. doi: $10.1101 / 2021.03 .24 .436778$

Deng, W., Cruz, B. N., \& Neuer, S. (2016). Effects of nutrient limitation on cell growth, TEP production and aggregate formation of marine Synechococcus. Aquatic Microbial Ecology: International Journal, 78(1), 39-49.

Deng, W., Monks, L., \& Neuer, S. (2015). Effects of clay minerals on the aggregation and subsequent settling of marine Synechococcus. Limnology and Oceanography, 60(3), 805-816.

Dorrell, R. G., Azuma, T., Nomura, M., de Kerdrel, G. A., Paoli, L., Yang, S., ... Kamikawa, chrysophytes. Proceedings of the National Academy of Sciences, Vol. 116, pp. 69146923. doi: 10.1073/pnas. 1819976116 
Garczarek, L. (2016). Delineating ecologically significant taxonomic units from global patterns of marine picocyanobacteria. Proceedings of the National Academy of Sciences of the United States of America, 113(24), E3365-E3374.

Field, C. B., Behrenfeld, M. J., Randerson, J. T., \& Falkowski, P. (1998). Primary production 237-240.

Foster, R. A., Collier, J. L., \& Carpenter, E. J. (2006). Reverse transcription pcr amplification of cyanobacterial symbiont 16s rRNA sequences from single non-photosynthetic eukaryotic marine planktonic host cells1. Journal of Phycology, 42(1), 243-250.

Fuller, N. J., Campbell, C., Allen, D. J., Pitt, F. D., Zwirglmaier, K., Le Gall, F., ... Scanlan, D. J. (2006). Analysis of photosynthetic picoeukaryote diversity at open ocean sites in the Arabian Sea using a PCR biased towards marine algal plastids. Aquatic Microbial Ecology, Vol. 43, pp. 79-93. doi: 10.3354/ame043079

Fuller, N. J., Tarran, G. A., Cummings, D. G., Woodward, E. M. S., Orcutt, K. M., Yallop, M., ... Scanlan, D. J. (2006). Molecular analysis of photosynthetic picoeukaryote community structure along an Arabian Sea transect. Limnology and Oceanography, Vol. 51, pp.

Gasol, J. M., \& Morán, X. A. G. (2015). Flow cytometric determination of microbial abundances and its use to obtain indices of community structure and relative activity. In Springer Protocols Handbooks (pp. 159-187). Berlin, Heidelberg: Springer Berlin Heidelberg.

Godhe, A., Asplund, M. E., Harnstrom, K., Saravanan, V., Tyagi, A., \& Karunasagar, I. (2008). Quantification of Diatom and Dinoflagellate Biomasses in Coastal Marine Seawater Samples by Real-Time PCR. Applied and Environmental Microbiology, Vol. 74, pp. 7174-7182. doi: 10.1128/aem.01298-08

Gong, W., \& Marchetti, A. (2019). Estimation of 18 S Gene Copy Number in Marine Eukaryotic Plankton Using a Next-Generation Sequencing Approach. Frontiers in Marine 
Science, Vol. 6. doi: 10.3389/fmars.2019.00219

938 Green, B. R. (2011). Chloroplast genomes of photosynthetic eukaryotes. The Plant Journal, Vol. 66, pp. 34-44. doi: 10.1111/j.1365-313x.2011.04541.x

Grigoriev, I. V., Hayes, R. D., Calhoun, S., Kamel, B., Wang, A., Ahrendt, S., ... Kuo, A. 49(D1), D1004-D1011.

Guidi, L., Stemmann, L., Jackson, G. A., Ibanez, F., Claustre, H., Legendre, L., ... Gorskya, G. (2009). Effects of phytoplankton community on production, size, and export of large aggregates: A world-ocean analysis. Limnology and Oceanography, 54(6), 1951-1963.

Guillou, L., Bachar, D., Audic, S., Bass, D., Berney, C., Bittner, L., ... Christen, R. (2013). The Protist Ribosomal Reference database (PR2): a catalog of unicellular eukaryote small sub-unit rRNA sequences with curated taxonomy. Nucleic Acids Research, 41(Database issue), D597-D604.

Guindon, S., Dufayard, J.-F., Lefort, V., Anisimova, M., Hordijk, W., \& Gascuel, O. (2010).

Heller, P., Tripp, H. J., Turk-Kubo, K., \& Zehr, J. P. (2014). ARBitrator: a software pipeline for on-demand retrieval of auto-curated nifH sequences from GenBank. Bioinformatics , 30(20), 2883-2890.

Hingamp, P., Grimsley, N., Acinas, S. G., Clerissi, C., Subirana, L., Poulain, J., ... Ogata, H. (2013). Exploring nucleo-cytoplasmic large DNA viruses in Tara Oceans microbial metagenomes. The ISME Journal, 7(9), 1678-1695.

Hiramatsu, T., Nakamura, S., Misumi, O., Kuroiwa, T., \& Nakamura, S. (2006). Morphological changes in mitochondrial and chloroplast nucleoids and mitochondia during the 
(2019). Global Trends in Marine Plankton Diversity across Kingdoms of Life. Cell, 179(5), 1084-1097.e21.

Jaffe, A. L., Castelle, C. J., Dupont, C. L., \& Banfield, J. F. (2019). Lateral Gene Transfer Shapes the Distribution of RuBisCO among Candidate Phyla Radiation Bacteria and DPANN Archaea. Molecular Biology and Evolution, 36(3), 435-446.

Kanehisa, M. (2000). KEGG: Kyoto Encyclopedia of Genes and Genomes. Nucleic Acids Research, Vol. 28, pp. 27-30. doi: 10.1093/nar/28.1.27 Tools for Functional Characterization of Genome and Metagenome Sequences. Journal

974 Katoh, K., \& Standley, D. M. (2013). MAFFT multiple sequence alignment software version 7: improvements in performance and usability. Molecular Biology and Evolution, 30(4), $772-780$.

Keeling, P. J., Burki, F., Wilcox, H. M., Allam, B., Allen, E. E., Amaral-Zettler, L. A., ... Worden, A. Z. (2014). The Marine Microbial Eukaryote Transcriptome Sequencing Project (MMETSP): illuminating the functional diversity of eukaryotic life in the oceans through transcriptome sequencing. PLoS Biology, 12(6), e1001889.

Kembel, S. W., Wu, M., Eisen, J. A., \& Green, J. L. (2012). Incorporating 16S gene copy number information improves estimates of microbial diversity and abundance. PLoS Computational Biology, 8(10), e1002743.

Kim, M., Choi, D. H., \& Park, M. G. (2021). Cyanobiont genetic diversity and host specificity of cyanobiont-bearing dinoflagellate Ornithocercus in temperate coastal waters. Scientific Reports, 11(1), 9458.

Kirkham, A. R., Jardillier, L. E., Tiganescu, A., Pearman, J., Zubkov, M. V., \& Scanlan, D. J. (2011). Basin-scale distribution patterns of photosynthetic picoeukaryotes along an 
Atlantic Meridional Transect. Environmental Microbiology, Vol. 13, pp. 975-990. doi:

Kirkham, A. R., Lepère, C., Jardillier, L. E., Not, F., Bouman, H., Mead, A., \& Scanlan, D. J. (2013). A global perspective on marine photosynthetic picoeukaryote community structure. The ISME Journal, Vol. 7, pp. 922-936. doi: 10.1038/ismej.2012.166

Kono, T., Mehrotra, S., Endo, C., Kizu, N., Matusda, M., Kimura, H., ... Ashida, H. (2017). A RuBisCO-mediated carbon metabolic pathway in methanogenic archaea. Nature Communications, Vol. 8. doi: 10.1038/ncomms14007

Koumandou, V. L., \& Howe, C. J. (2007). The Copy Number of Chloroplast Gene Minicircles Changes Dramatically with Growth Phase in the Dinoflagellate Amphidinium operculatum. Protist, Vol. 158, pp. 89-103. doi: 10.1016/j.protis.2006.08.003 Evolution, 35(6), 1547-1549.

Lamb, P. D., Hunter, E., Pinnegar, J. K., Creer, S., Davies, R. G., \& Taylor, M. I. (2019). How quantitative is metabarcoding: A meta-analytical approach. Molecular Ecology, 28(2), $420-430$. Intraspecific Variation in rDNA Copy Number Affect Analysis of Microbial Communities? Trends in Microbiology, 29(1), 19-27.

Lebrun, E., Santini, J. M., Brugna, M., Ducluzeau, A.-L., Ouchane, S., Schoepp-Cothenet, B., ... Nitschke, W. (2006). The Rieske protein: a case study on the pitfalls of multiple sequence alignments and phylogenetic reconstruction. Molecular Biology and Evolution, 23(6), 1180-1191.

Lepère, C., Vaulot, D., \& Scanlan, D. J. (2009). Photosynthetic picoeukaryote community structure in the South East Pacific Ocean encompassing the most oligotrophic waters on Earth. Environmental Microbiology, Vol. 11, pp. 3105-3117. doi: 10.1111/j.1462- 
1019 Li, H., \& Durbin, R. (2009). Fast and accurate short read alignment with Burrows-Wheeler 1020 transform. Bioinformatics , 25(14), 1754-1760.

1021 Liu, Z., Lozupone, C., Hamady, M., Bushman, F. D., \& Knight, R. (2007). Short pyrosequencing reads suffice for accurate microbial community analysis. Nucleic Acids Research, Vol. 35, pp. e120-e120. doi: 10.1093/nar/gkm541

Li, W., \& Godzik, A. (2006). Cd-hit: a fast program for clustering and comparing large sets of protein or nucleotide sequences. Bioinformatics, Vol. 22, pp. 1658-1659. doi:

Logares, R., Audic, S., Santini, S., Pernice, M. C., de Vargas, C., \& Massana, R. (2012). Acinas, S. G. (2014). Metagenomic 16S rDNA Illumina tags are a powerful alternative to amplicon sequencing to explore diversity and structure of microbial communities.

Mäki, A., Salmi, P., Mikkonen, A., Kremp, A., \& Tiirola, M. (2017). Sample preservation, DNA

1039 Malviya, S., Scalco, E., Audic, S., Vincent, F., Veluchamy, A., Poulain, J., ... \& Bowler, C.

1040 (2016). Insights into global diatom distribution and diversity in the world's ocean. 
Man-Aharonovich, D., Philosof, A., Kirkup, B. C., Le Gall, F., Yogev, T., Berman-Frank, I., ... 4(8), 1044-1052.

1050

Masquelier, S., \& Vaulot, D. (2008). Distribution of micro-organisms along a transect in the South-East Pacific Ocean (BIOSOPE cruise) using epifluorescence microscopy. Biogeosciences , 5(2), 311-321.

McDonald, S. M., Sarno, D., Scanlan, D. J., \& Zingone, A. (2007). Genetic diversity of eukaryotic ultraphytoplankton in the Gulf of Naples during an annual cycle. Aquatic Microbial Ecology, Vol. 50, pp. 75-89. doi: 10.3354/ame01148

Medinger, R., Nolte, V., Pandey, R. V., Jost, S., Ottenwälder, B., Schlötterer, C., \& Boenigk, J. (2010). Diversity in a hidden world: potential and limitation of next-generation sequencing for surveys of molecular diversity of eukaryotic microorganisms. Molecular Ecology, Vol. 19, pp. 32-40. doi: 10.1111/j.1365-294x.2009.04478.x

Milanese, A., Mende, D. R., Paoli, L., Salazar, G., Ruscheweyh, H.-J., Cuenca, M., ... Sunagawa, S. (2019). Microbial abundance, activity and population genomic profiling with mOTUs2. Nature Communications, 10(1), 1014.

Mohamed, M. E., Zaar, A., Ebenau-Jehle, C., \& Fuchs, G. (2001). Reinvestigation of a new type of aerobic benzoate metabolism in the proteobacterium Azoarcus evansii. Journal of Bacteriology, 183(6), 1899-1908.

Moore, R. B., Oborník, M., Janouskovec, J., Chrudimský, T., Vancová, M., Green, D. H., ... Carter, D. A. (2008). A photosynthetic alveolate closely related to apicomplexan parasites. Nature, 451(7181), 959-963.

Nakayama, T., Kamikawa, R., Tanifuji, G., Kashiyama, Y., Ohkouchi, N., Archibald, J. M., \& Inagaki, Y. (2014). Complete genome of a nonphotosynthetic cyanobacterium in a diatom reveals recent adaptations to an intracellular lifestyle. Proceedings of the 
1073 Nakayama, T., Nomura, M., Takano, Y., Tanifuji, G., Shiba, K., Inaba, K., ... Kawata, M.

1074 (2019). Single-cell genomics unveiled a cryptic cyanobacterial lineage with a worldwide distribution hidden by a dinoflagellate host. Proceedings of the National Academy of Sciences of the United States of America, 116(32), 15973-15978.

Obiol, A., Giner, C. R., Sánchez, P., Duarte, C. M., Acinas, S. G., \& Massana, R. (2020). A metagenomic assessment of microbial eukaryotic diversity in the global ocean. Molecular Ecology Resources, 20(3). doi: 10.1111/1755-0998.13147 (2020). vegan: Community Ecology Package. R package version 2.5-7. https://CRAN.Rproject.org/package=vegan

Oldenburg, D. J., \& Bendich, A. J. (2004). Changes in the structure of DNA molecules and the amount of DNA per plastid during chloroplast development in maize. Journal of Molecular Biology, 344(5), 1311-1330.

Parada, A. E., Needham, D. M., \& Fuhrman, J. A. (2016). Every base matters: assessing small subunit rRNA primers for marine microbiomes with mock communities, time series and global field samples. Environmental Microbiology, 18(5), 1403-1414.

Paradis, E., \& Schliep, K. (2019). ape 5.0: an environment for modern phylogenetics and evolutionary analyses in R. Bioinformatics, Vol. 35, pp. 526-528. doi:

1092 Paul, J. H., Alfreider, A., \& Wawrik, B. (2000). Micro- and macrodiversity in rbcL sequences 1093 in ambient phytoplankton populations from the southeastern Gulf of Mexico. Marine 1094 Ecology Progress Series, Vol. 198, pp. 9-18. doi: 10.3354/meps198009

1095 Pawlowski, J., Audic, S., Adl, S., Bass, D., Belbahri, L., Berney, C., ... de Vargas, C. (2012). 1096 CBOL Protist Working Group: Barcoding Eukaryotic Richness beyond the Animal, Plant, 1097 and Fungal Kingdoms. PLoS Biology, Vol. 10, p. e1001419. doi:

$1098 \quad$ 10.1371/journal.pbio.1001419 
1099 Pawlowski, J., Lejzerowicz, F., Apotheloz-Perret-Gentil, L., Visco, J., \& Esling, P. (2016).

1100 Protist metabarcoding and environmental biomonitoring: Time for change. European 1101 Journal of Protistology, 55(Pt A), 12-25.

1102 Pesant, S., Not, F., Picheral, M., Kandels-Lewis, S., Le Bescot, N., Gorsky, G., ... Tara Oceans Consortium Coordinators. (2015). Open science resources for the discovery and analysis of Tara Oceans data. Scientific Data, 2, 150023. Pierella Karlusich, J. J., \& Carrillo, N. (2017). Evolution of the acceptor side of photosystem I: ferredoxin, flavodoxin, and ferredoxin-NADP oxidoreductase.

1108 Pierella Karlusich, J. J., Ceccoli, R. D., Graña, M., Romero, H., \& Carrillo, N. (2015). Environmental selection pressures related to iron utilization are involved in the loss of the flavodoxin gene from the plant genome. Genome Biology and Evolution, 7(3), 750767.

1112 Pierella Karlusich, J. J., Ibarbalz, F. M., \& Bowler, C. (2020). Phytoplankton in the Ocean. 1113 Annual Review of Marine Science, 12, 233-265.

1114 Pierella Karlusich, J. J., Pelletier, E., Lombard, F., Carsique, M., Dvorak, E., Colin, S., ... 1115 Foster, R. A. (2021). Global distribution patterns of marine nitrogen-fixers by imaging and molecular methods. Nature Communications, 12(1), 4160.

1117 Pinto, A. J., \& Raskin, L. (2012). PCR biases distort bacterial and archaeal community structure in pyrosequencing datasets. PloS One, 7(8), e43093.

1119 Polz, M. F., \& Cavanaugh, C. M. (1998). Bias in template-to-product ratios in multitemplate $1120 \quad$ PCR. Applied and Environmental Microbiology, 64(10), 3724-3730.

1121 Quast, C., Pruesse, E., Yilmaz, P., Gerken, J., Schweer, T., Yarza, P., ... Glöckner, F. O. (2013). The SILVA ribosomal RNA gene database project: improved data processing and web-based tools. Nucleic Acids Research, 41(Database issue), D590-D596.

1124 Roy, S., Jagus, R., \& Morse, D. (2018). Translation and Translational Control in 
1126 Rusch, D. B., Halpern, A. L., Sutton, G., Heidelberg, K. B., Williamson, S., Yooseph, S., ...

1127 Craig Venter, J. (2007). The Sorcerer II Global Ocean Sampling Expedition: Northwest

1128 Atlantic through Eastern Tropical Pacific. PLoS Biology, Vol. 5, p. e77. doi:

$1129 \quad$ 10.1371/journal.pbio.0050077

1130 Salazar, G., Paoli, L., Alberti, A., Huerta-Cepas, J., Ruscheweyh, H.-J., Cuenca, M., ...

1131 Wincker, P. (2019). Gene Expression Changes and Community Turnover Differentially

1132 Shape the Global Ocean Metatranscriptome. Cell, Vol. 179, pp. 1068-1083.e21. doi:

$1133 \quad$ 10.1016/j.cell.2019.10.014

1134 Saldarriaga, J. F., Taylor, F. J., Keeling, P. J., \& Cavalier-Smith, T. (2001). Dinoflagellate

1135 nuclear SSU rRNA phylogeny suggests multiple plastid losses and replacements.

$1136 \quad$ Journal of Molecular Evolution, 53(3), 204-213.

1137 Santoferrara, L. F. (2019). Current practice in plankton metabarcoding: optimization and error management. Journal of Plankton Research, 41(5), 571-582.

1139 Shannon, P., Markiel, A., Ozier, O., Baliga, N. S., Wang, J. T., Ramage, D., ... Ideker, T.

1140 (2003). Cytoscape: a software environment for integrated models of biomolecular 1141 interaction networks. Genome Research, 13(11), 2498-2504.

1142 Shi, X. L., Lepère, C., Scanlan, D. J., \& Vaulot, D. (2011). Plastid 16S rRNA gene diversity 1143 among eukaryotic picophytoplankton sorted by flow cytometry from the South Pacific Ocean. PloS One, 6(4), e18979.

1145 Singer, A., Poschmann, G., Mühlich, C., Valadez-Cano, C., Hänsch, S., Hüren, V., ... 1146 Nowack, E. C. M. (2017). Massive Protein Import into the Early-Evolutionary-Stage 1147 Photosynthetic Organelle of the Amoeba Paulinella chromatophora. Current Biology: $1148 \quad C B, 27(18), 2763-2773 . e 5$.

1149 Stamatakis, A. (2014). RAxML version 8: a tool for phylogenetic analysis and post-analysis of $1150 \quad$ large phylogenies. Bioinformatics , 30(9), 1312-1313.

1151 Starke, R., Pylro, V. S., \& Morais, D. K. (2020). 16S rRNA Gene Copy Number Normalization 1152 Does Not Provide More Reliable Conclusions in Metataxonomic Surveys. Microbial 
1154 Sunagawa, S., Coordinators, T. O., Acinas, S. G., Bork, P., Bowler, C., Eveillard, D., ... de 1155 Vargas, C. (2020). Tara Oceans: towards global ocean ecosystems biology. Nature Reviews Microbiology. doi: 10.1038/s41579-020-0364-5

1157 Sunagawa, S., Mende, D. R., Zeller, G., Izquierdo-Carrasco, F., Berger, S. A., Kultima, J. R., ... Bork, P. (2013). Metagenomic species profiling using universal phylogenetic marker genes. Nature Methods, 10(12), 1196-1199.

1160 Tabita, F. R., Hanson, T. E., Satagopan, S., Witte, B. H., \& Kreel, N. E. (2008). Phylogenetic and evolutionary relationships of Rubis $\mathrm{CO}$ and the RubisCO-like proteins and the

Thompson, A. W., Foster, R. A., Krupke, A., Carter, B. J., Musat, N., Vaulot, D., ... Zehr, J. functional lessons provided by diverse molecular forms. Philosophical Transactions of the Royal Society of London. Series B, Biological Sciences, 363(1504), 2629-2640. P. (2012). Unicellular cyanobacterium symbiotic with a single-celled eukaryotic alga. Science, 337(6101), 1546-1550.

van der Loos, L. M., \& Nijland, R. (2021). Biases in bulk: DNA metabarcoding of marine communities and the methodology involved. Molecular Ecology, 30(13), 3270-3288.

1172 Veit, S., Takeda, K., Tsunoyama, Y., Baymann, F., Nevo, R., Reich, Z., ... Rexroth, S. 1173 (2016). Structural and functional characterisation of the cyanobacterial PetC3 Rieske protein family. Biochimica et Biophysica Acta, 1857(12), 1879-1891.

Větrovský, T., \& Baldrian, P. (2013). The variability of the 16 S rRNA gene in bacterial genomes and its consequences for bacterial community analyses. PloS One, 8(2),

1178 Wang, J., Chu, S., Zhu, Y., Cheng, H., \& Yu, D. (2015). Positive selection drives 1179 neofunctionalization of the UbiA prenyltransferase gene family. Plant Molecular Biology, 
87(4-5), 383-394.

Wear, E. K., Wilbanks, E. G., Nelson, C. E., \& Carlson, C. A. (2018). Primer selection impacts specific population abundances but not community dynamics in a monthly timeseries $16 \mathrm{~S}$ rRNA gene amplicon analysis of coastal marine bacterioplankton.

Wickham, H. (2016). ggplot2: Elegant Graphics for Data Analysis. Springer.

Yu, G. (2018) scatterpie: Scatter pie plot. https://CRAN.R-project.org/package=scatterpie

Yoon, H. S., Reyes-Prieto, A., Melkonian, M., \& Bhattacharya, D. (2006). Minimal plastid genome evolution in the Paulinella endosymbiont. Current Biology: CB, 16(17), R670R672.

Yuasa, T., Horiguchi, T., Mayama, S., Matsuoka, A., \& Takahashi, O. (2012). Ultrastructural

Zallot, R., Oberg, N., \& Gerlt, J. A. (2019). The EFI web resource for genomic enzymology tools: leveraging protein, genome, and metagenome databases to discover novel enzymes and metabolic pathways. Biochemistry, 58(41), 4169-4182.

Zehr, J. P., \& Paerl, H. (1998). Nitrogen fixation in the marine environment: genetic potential and nitrogenase expression. Molecular Approaches to the Study of the Ocean, pp. 285301. doi: 10.1007/978-94-011-4928-0_13

Zeidner, G., Preston, C. M., Delong, E. F., Massana, R., Post, A. F., Scanlan, D. J., \& Beja, O. (2003). Molecular diversity among marine picophytoplankton as revealed by psbA analyses. Environmental Microbiology, Vol. 5, pp. 212-216. doi: 10.1046/j.14622920.2003.00403.x

Zeidner, G., Preston, C. M., Delong, E. F., Massana, R., Post, A. F., Scanlan, D. J., \& Béjà, O. (2003). Molecular diversity among marine picophytoplankton as revealed by $p s b A$ analyses. Environmental Microbiology, 5(3), 212-216.

Zhu, F., Massana, R., Not, F., Marie, D., \& Vaulot, D. (2005). Mapping of picoeucaryotes in 
bioRxiv preprint doi: https://doi.org/10.1101/2021.05.28.446125; this version posted September $19,2021$. The copyright holder for this preprint (which was not certified by peer review) is the author/funder, who has granted bioRxiv a license to display the preprint in perpetuity. It is made available under aCC-BY 4.0 International license. 
1210 Table I: Tara Oceans datasets relevant to the current study

\begin{tabular}{|c|c|c|c|c|c|}
\hline Target & $\begin{array}{l}\text { Size } \\
\text { fraction }\end{array}$ & Dataset & Dataset construction & $\begin{array}{l}\text { Subset used in the current } \\
\text { work }\end{array}$ & References and link \\
\hline $\begin{array}{l}\text { Prokaryotes } \\
\text { and } \\
\text { picoeukaryotes }\end{array}$ & $0.2-3 \mu \mathrm{m}$ & $\begin{array}{l}\text { 16S miTags } \\
\text { (metagenomic } \\
\text { Illumina tags) }\end{array}$ & $\begin{array}{l}16 \mathrm{~S} \text { rRNA gene sequences were } \\
\text { identified in metagenomes and } \\
\text { assembled. OTUs were defined at } 97 \% \\
\text { identity cut-off }\end{array}$ & $\begin{array}{l}726 \text { OTUs assigned to } \\
\text { picophytoplankton }(258 \\
\text { cyanobacteria }+468 \\
\text { eukaryotic phytoplankton })\end{array}$ & $\begin{array}{l}\text { Salazar et al., } 2019 \\
\text { https://www.ocean- } \\
\text { microbiome.org/ }\end{array}$ \\
\hline Eukaryotes & $\begin{array}{l}5 \text { size } \\
\text { fractions } \\
(0.8-2000 \\
\mu \mathrm{m})^{*}\end{array}$ & $\begin{array}{l}18 \mathrm{~S} \text { rRNA gene } \\
\text { (V9 region) } \\
\text { metabarcoding }\end{array}$ & $\begin{array}{l}\text { PCR amplification of the } V 9 \text { region }(\sim 130 \\
\text { base pairs length) of } 18 \mathrm{~S} \text { rRNA gene } \\
\text { followed by the high-throughput } \\
\text { sequencing of the amplicons, which were } \\
\text { clustered into OTUs using SWARM }\end{array}$ & $\begin{array}{l}31,930 \text { OTUs assigned to } \\
\text { eukaryotic phytoplankton } \\
\text { (including photosynthetic } \\
\text { dinoflagellates and } \\
\text { chrysophytes) }\end{array}$ & $\begin{array}{l}\text { de Vargas et al., 2015; } \\
\text { lbarbalz et al., } 2019 \\
\text { https://zenodo.org/record } \\
3768510 \# . X r a b y 6 g z Y 2 w\end{array}$ \\
\hline $\begin{array}{l}\text { Prokaryotes } \\
\text { and } \\
\text { picoeukaryotes }\end{array}$ & $0.2-3 \mu \mathrm{m}$ & $\begin{array}{l}\text { Ocean Microbial } \\
\text { Reference } \\
\text { Gene Catalog } \\
\text { (OM-RGC-v2) }\end{array}$ & $\begin{array}{l}\text { Unigenes assembled from metagenomes } \\
\text { and clustered at } 95 \% \text { identity. } \\
\text { Metagenomic and metatranscriptomic } \\
\text { reads were then mapped on these } \\
\text { unigenes. }\end{array}$ & $\begin{array}{l}307 \text { psbO sequences from } \\
\text { cyanobacteria and eukaryotic } \\
\text { phytoplankton }\end{array}$ & $\begin{array}{l}\text { Salazar et al., } 2019 \\
\text { https://www.ocean- } \\
\text { microbiome.org/ }\end{array}$ \\
\hline Eukaryotes & $\begin{array}{l}5 \text { size } \\
\text { fractions } \\
(0.8-2000 \\
\mu \mathrm{m})^{*}\end{array}$ & $\begin{array}{l}\text { Marine Atlas of } \\
\text { Tara Oceans } \\
\text { Unigenes } \\
\text { (MATOU-v1) }\end{array}$ & $\begin{array}{l}\text { Transcribed sequences assembled from } \\
\text { poly-A+ metatranscriptomes and } \\
\text { clustered at } 95 \% \text { identity. Metagenomic } \\
\text { and metatranscriptomic reads were then } \\
\text { mapped on these unigenes. }\end{array}$ & $\begin{array}{l}10,646 \mathrm{psbO} \text { sequences from } \\
\text { eukaryotic phytoplankton }\end{array}$ & $\begin{array}{l}\text { Carradec et al., } 2018 \\
\text { http:// } \\
\text { www.genoscope.cns.fr/ } \\
\text { tara/ }\end{array}$ \\
\hline $\begin{array}{l}\text { Prokaryotes } \\
\text { and eukaryotes }\end{array}$ & $\begin{array}{l}6 \text { size } \\
\text { fractions } \\
(0.2-2000 \\
\mu \mathrm{m})^{* *}\end{array}$ & Metagenomes & Raw metagenomic reads & $\begin{array}{l}\sim 3.2 \text { million metagenomic } \\
\text { reads aligned to a curated } \\
\text { database of } p s b O \text { sequences }\end{array}$ & $\begin{array}{l}\text { EBI accessions: } \\
\text { PRJEB1787 PRJEB1788 } \\
\text { PRJEB4352 PRJEB4419 } \\
\text { PRJEB9691 PRJEB9740 } \\
\text { PRJEB9742 }\end{array}$ \\
\hline $\begin{array}{l}\text { Prokaryotes } \\
\text { and eukaryotes }\end{array}$ & $<200 \mu \mathrm{m}$ & Flow cytometry & & $\begin{array}{l}\text { Abundances and biovolume of } \\
\text { picocyanobacteria and }\end{array}$ & $\begin{array}{l}\text { Hingamp et al. 2013; } \\
\text { Gasol and Morán } 2015 \\
\text { https:// }\end{array}$ \\
\hline
\end{tabular}




\begin{tabular}{|c|c|c|c|c|}
\hline & & & eukaryotic picophytoplankton & $\begin{array}{l}\text { data.mendeley.com/ } \\
\text { datasets/p9r9wtjkm/2 }\end{array}$ \\
\hline Eukaryotes & $5-20 \mu \mathrm{m}$ & $\begin{array}{l}\text { Confocal } \\
\text { microscopy }\end{array}$ & $\begin{array}{l}\text { Abundance and biovolume of } \\
\text { nanophytoplankton }\end{array}$ & $\begin{array}{l}\text { Colin et al., } 2017 \\
\text { https://www.ebi.ac.uk/ } \\
\text { biostudies/studies/S- } \\
\text { BSST51 }\end{array}$ \\
\hline Eukaryotes & $20-180 \mu \mathrm{m}$ & $\begin{array}{l}\text { Light } \\
\text { microscopy }\end{array}$ & $\begin{array}{l}\text { Abundance of } \\
\text { microphytoplankton }\end{array}$ & Malviya et al., 2016 \\
\hline Prokaryotes & $20-180 \mu \mathrm{m}$ & $\begin{array}{l}\text { Confocal } \\
\text { microscopy }\end{array}$ & $\begin{array}{l}\text { Abundance of the symbiotic } \\
\text { cyanobacteria } \\
\text { Richelia/Calothrix and the } \\
\text { colony-forming } \\
\text { Trichodesmium }\end{array}$ & $\begin{array}{l}\text { Pierella Karlusich et al., } \\
2021 \\
\text { https://static- } \\
\text { content.springer.com/ } \\
\text { esm/art } \\
\% 3 A 10.1038 \% 2 F s 41467 \text { - } \\
021-24299-y / \\
\text { MediaObjects/ } \\
\text { 41467_2021_24299_MO } \\
\text { ESM11_ESM.xlsx }\end{array}$ \\
\hline
\end{tabular}

$1211{ }^{*} 0.8-5 \mu \mathrm{m}, 5-20 \mu \mathrm{m}, 20-180 \mu \mathrm{m}, 180-2000 \mu \mathrm{m}$

$1212{ }^{* *} 0.2-3 \mu \mathrm{m}, 0.8-5 \mu \mathrm{m}, 5-20 \mu \mathrm{m}, 20-180 \mu \mathrm{m}, 180-2000 \mu \mathrm{m}$ 
1213 Table II: List of nuclear-encoded photosynthetic genes present in all cyanobacteria and eukaryotic phytoplankton. These genes are always nuclear1214 encoded, with the exception of the amoeba of the genus Paulinella (Fig. 2A), which has gained its plastid only very recently and independently of the event at 1215 the origin of all other known plastids (Singer et al., 2017; Yoon, Reyes-Prieto, Melkonian, \& Bhattacharya, 2006).

\begin{tabular}{|c|c|c|c|c|c|}
\hline Gene & Pathway & Function & Copies & Non-photosynthetic homologs & References \\
\hline $\begin{array}{l}\text { prk } \\
\text { (phosphoribulokinase) }\end{array}$ & $\begin{array}{l}\text { Calvin-Benson- } \\
\text { Bassham cycle }\end{array}$ & $\begin{array}{l}\text { phosphorylation of ribulose-5-phosphate } \\
\text { to ribulose- } 1,5 \text {-bisphosphate, the } \\
\text { RuBisCO substrate }\end{array}$ & 1 & PRKs from archaea and bacteria & $\begin{array}{l}\text { (Jaffe, Castelle, Dupont, \& } \\
\text { Banfield, 2019; Kono et al., } \\
\text { 2017) }\end{array}$ \\
\hline $\begin{array}{l}\text { ch/G } \\
\text { (chlorophyll-a synthase) }\end{array}$ & $\begin{array}{l}\text { chlorophyll-a } \\
\text { biosynthesis }\end{array}$ & last step of chlorophyll-a biosynthesis & 1 & Prenyltransferases with UbiA domain & $\begin{array}{l}\text { (Wang, Chu, Zhu, Cheng, \& } \\
\text { Yu, 2015) }\end{array}$ \\
\hline $\begin{array}{l}\text { petH } \\
\text { (ferredoxin-NADP } \\
\text { oxidoreductase) }\end{array}$ & $\begin{array}{l}\text { Photosynthetic } \\
\text { electron } \\
\text { transport chain }\end{array}$ & $\begin{array}{l}\text { last step of the linear electron flow } \\
\text { (NADP }^{+} \text {reduction by ferredoxin or } \\
\text { flavodoxin) }\end{array}$ & $1-3$ & $\begin{array}{l}\text {-FNRs involved in nitrogen metabolism } \\
\text {-FNRs from non-photosynthetic plastids } \\
\text {-C-terminal region of benzoyl-CoA } \\
\text { oxygenase component A (BoxA) from } \\
\text { bacteria }\end{array}$ & $\begin{array}{l}\text { (Pierella Karlusich \& } \\
2017 \text { Carrillo, } \\
\text { Ebenamed, Zaar, } \\
\text { 2001) }\end{array}$ \\
\hline petC & $\begin{array}{l}\text { Photosynthetic } \\
\text { electron } \\
\text { transport chain }\end{array}$ & $\begin{array}{l}\text { Rieske subunit of the chloroplast Cyt } b_{6} f \\
\text { complex }\end{array}$ & $2-3$ & $\begin{array}{l}\text { Rieske proteins from mitochondria, } \\
\text { bacteria and archaea }\end{array}$ & $\begin{array}{l}\text { (Lebrun et al., 2006; Veit et } \\
\text { al., 2016) }\end{array}$ \\
\hline$p s b O$ & $\begin{array}{l}\text { Photosynthetic } \\
\text { electron } \\
\text { transport chain }\end{array}$ & $\begin{array}{l}\text { Manganese-stabilizing protein of } \\
\text { photosystem II }\end{array}$ & $1-2$ & No & $\begin{array}{l}\text { (Pierella Karlusich, Ceccoli, } \\
\text { Graña, Romero, \& Carrillo, } \\
\text { 2015) }\end{array}$ \\
\hline
\end{tabular}


bioRxiv preprint doi: https://doi.org/10.1101/2021.05.28.446125; this version posted September 19, 2021. The copyright holder for this preprint (which was not certified by peer review) is the author/funder, who has granted bioRxiv a license to display the preprint in perpetuity. It is made available under aCC-BY 4.0 International license.



Figure 1: Identification of nuclear-encoded core photosynthetic gene marker candidates. A) Presence and location of the genes encoding proteins involved in photosynthesis. The genes found to be core and nuclear-encoded are labelled in blue. The only exception is the amoeba of the genus Paulinella, which has gained its plastid very recently and independently of the event at the origin of all other known plastids, thus still retaining these genes in its plastid genome (Yoon et al. 2006; Singer et al. 2017). B) Phylogeny of PsbO protein. Translated sequences from genomes and transcriptomes of cultured phytoplanktonic species were used for the phylogeny reconstruction. The scale bar indicates the number of expected amino acid substitutions per site per unit of branch length. 
bioRxiv preprint doi: https://doi.org/10.1101/2021.05.28.446125; this version posted September 19, 2021. The copyright holder for this preprint (which was not certified by peer review) is the author/funder, who has granted bioRxiv a license to display the preprint in perpetuity. It is made available under aCC-BY 4.0 International license.
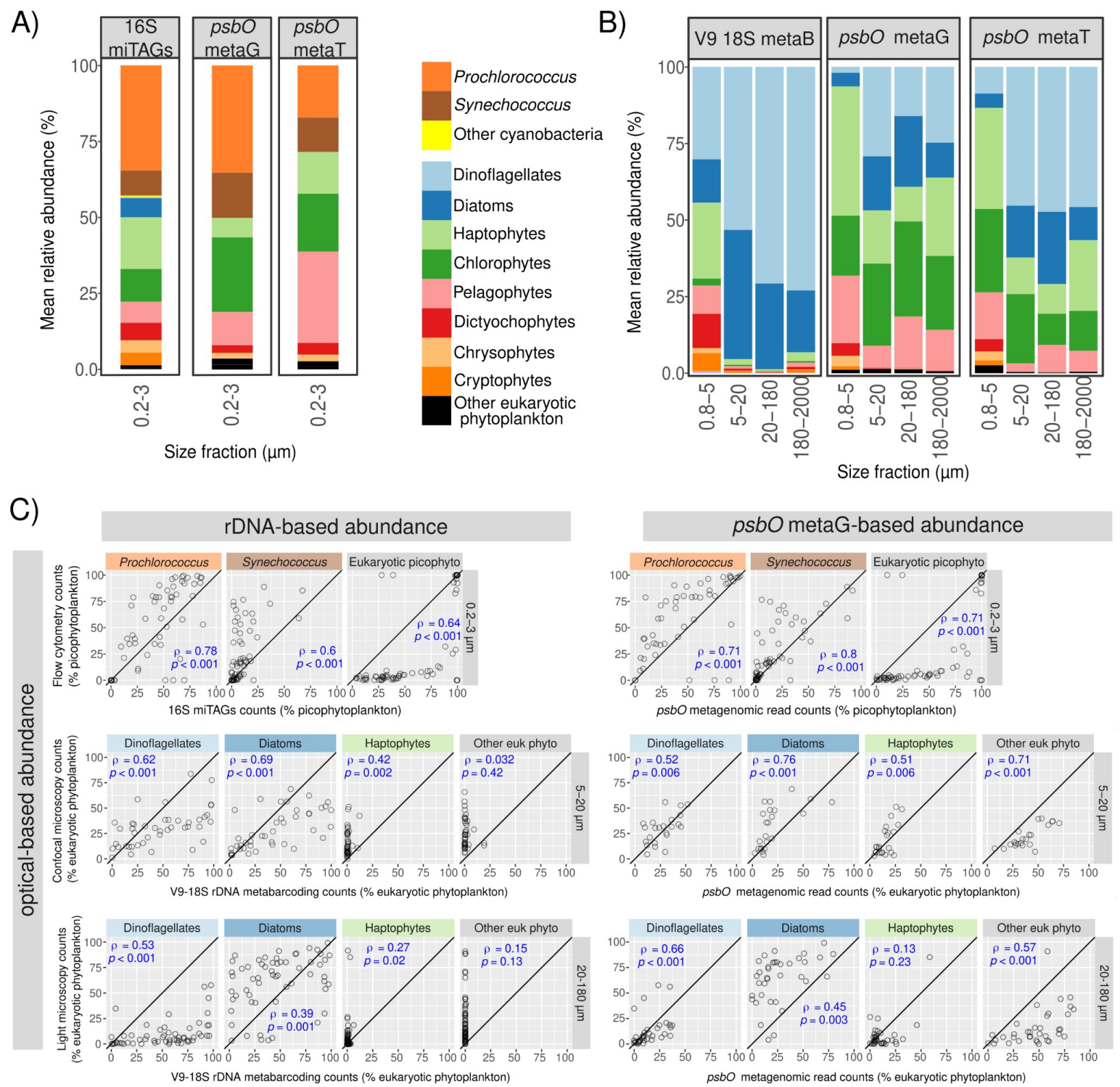

Figure 2: Congruence in relative abundances of the main phytoplankton groups based on different gene markers. A-B) Average relative abundances for all surface samples of each size fraction using different marker genes. In A, picocyanobacteria and eukaryotic picophytoplankton (0.2$3 \mu \mathrm{m}$ ) were analysed using 16S rRNA gene miTags and the metagenomic and metatranscriptomic read abundances for $p s b O$. In B, eukaryotic phytoplankton was analysed in larger size fractions using V9-18S rRNA gene amplicons and the metagenomic and (polyA-derived) metatranscriptomic psbO read abundances. C) Correlations between relative abundances of different phytoplankton groups obtained with optical versus DNA-based methodologies. In the upper panel, 16S rRNA gene miTags and $p s b \mathrm{O}$-based relative abundances in picophytoplankton were compared with flow cytometry counts (values displayed as \% total abundance of picophytoplankton). In the middle and lower panels, V918S rRNA gene metabarcoding and metagenomic $p s b O$ relative abundances were compared with confocal microscopy counts from size fraction $5-20 \mu \mathrm{m}$ and light microscopy counts from size fraction 20-180 $\mu \mathrm{m}$ (values displayed as \% total abundance of eukaryotic phytoplankton). It is worth mentioning that the molecular and microscopy data were generated from the same samples, while there were differences between molecular data of $0.2-3 \mu \mathrm{m}$ size fraction and flow cytometry data (see Methods). Axes are in the same scale and the diagonal line corresponds to a 1:1 slope. Spearman's rho correlation coefficients and p-values are displayed. The correlations of relative abundances between metatranscriptomic $p s b O$ reads and optical methods are shown in Figure S11. 

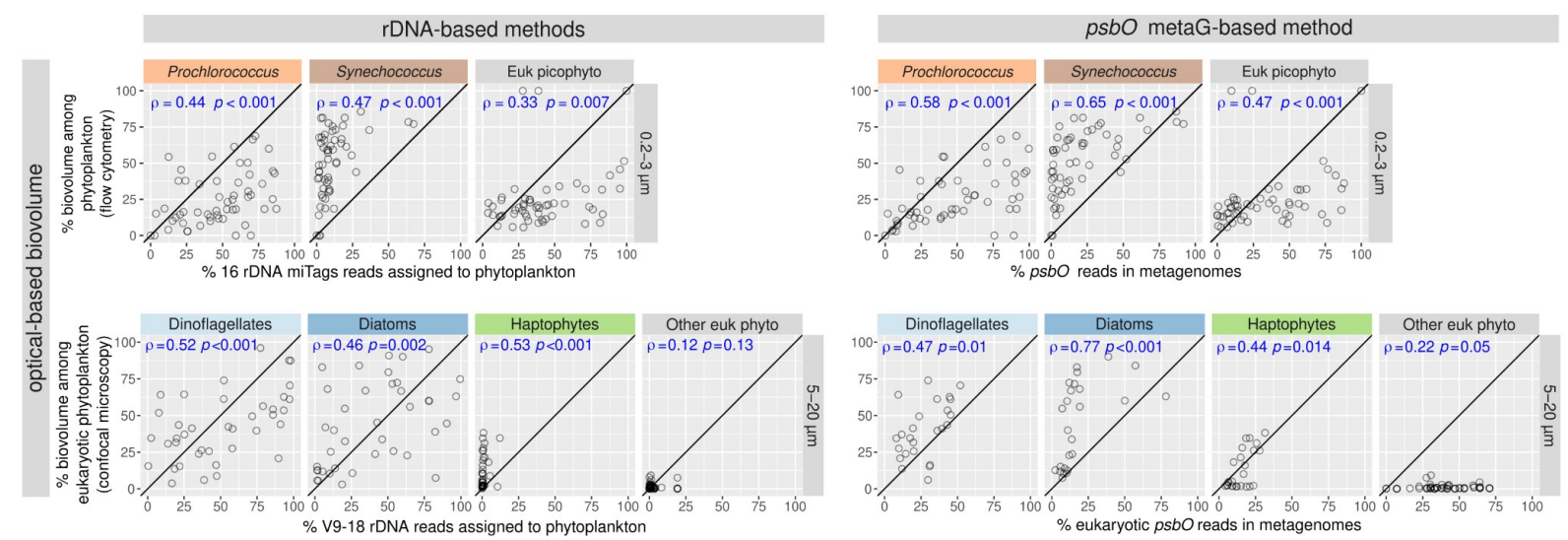

Figure 3: Correlation between relative biovolume (based on optical methods) and relative abundances based on different molecular methodologies. The upper panels show the correlations for picophytoplankton (size fraction 0.2-3 $\mu \mathrm{m}$ ). The vertical axis corresponds to the relative biovolume based on flow cytometry (values displayed as $\%$ total biovolume of picophytoplankton), while the horizontal axis corresponds to relative read abundance based on molecular methods: 16S miTAGs (left upper panel) and psbO metagenomic counts (right upper panel). The lower panels show the correlations for nanophytoplankton (size fraction 5-20 $\mu \mathrm{m}$ ). The vertical axis corresponds to the relative biovolume based on confocal microscopy quantification (values displayed as \% total abundance of eukaryotic phytoplankton), while the horizontal axis corresponds to relative read abundance based on molecular methods: V9-18S rRNA gene metabarcoding (left lower panel) and eukaryotic psbO metagenomic counts (right bottom panel). Spearman correlation coefficients and p-values are displayed in blue. Axis are in the same scale and the diagonal line corresponds to a 1:1 slope. 

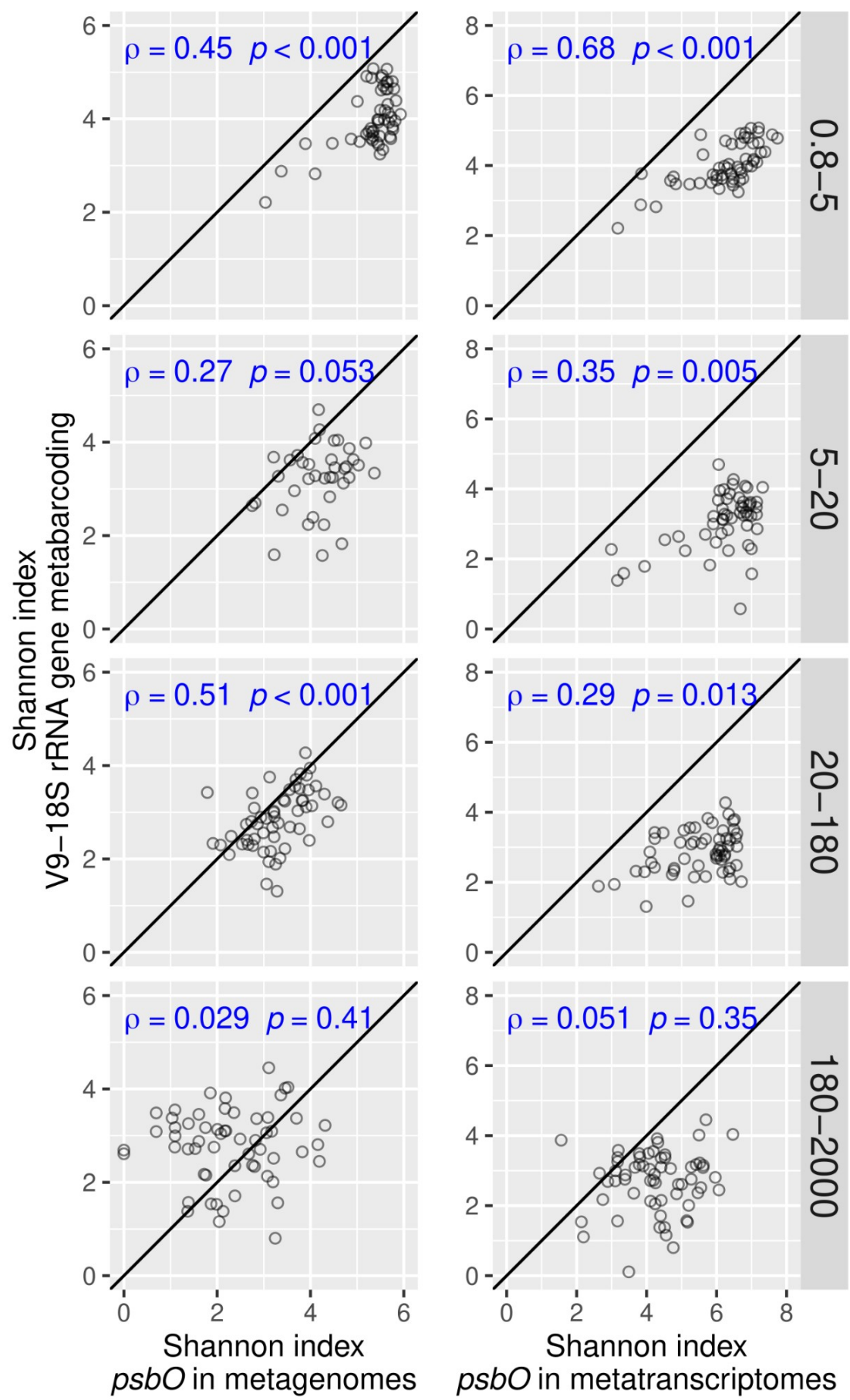
for eukaryotic phytoplankton communities. The values derived from $p s b O$ metagenomics (left) and metatranscriptomics (right) were compared with those derived from V9-18S rRNA gene metabarcoding. Spearman correlation coefficients and $p$-values are displayed in blue. Axis are in the same scale and the diagonal line corresponds to a 1:1 slope. 
a)

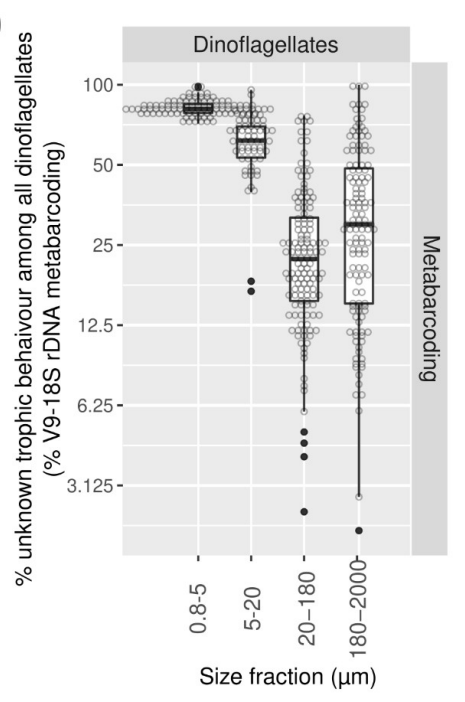

b)
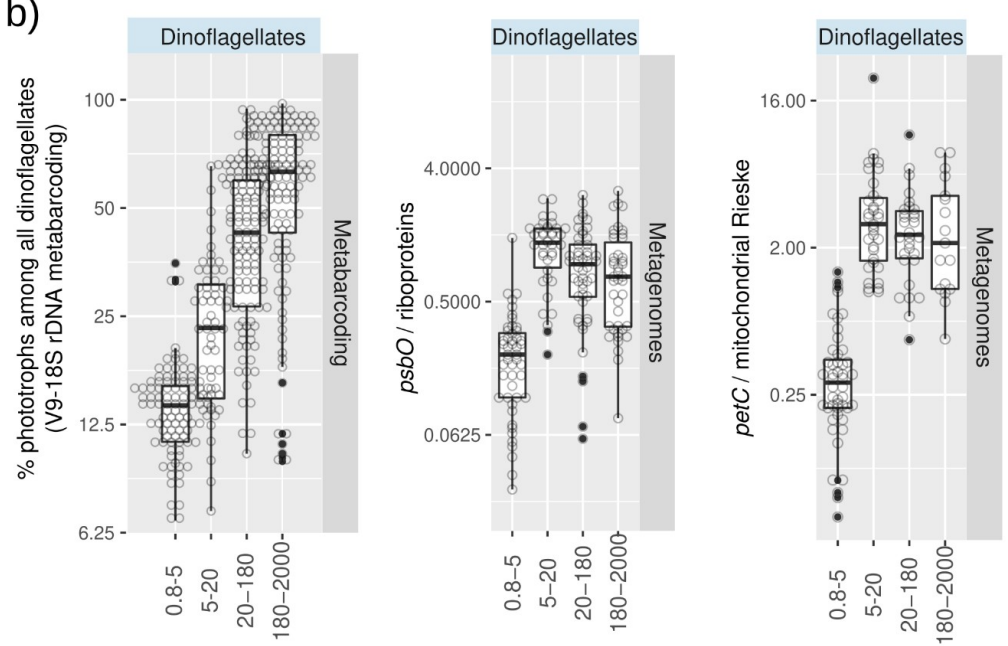

c)

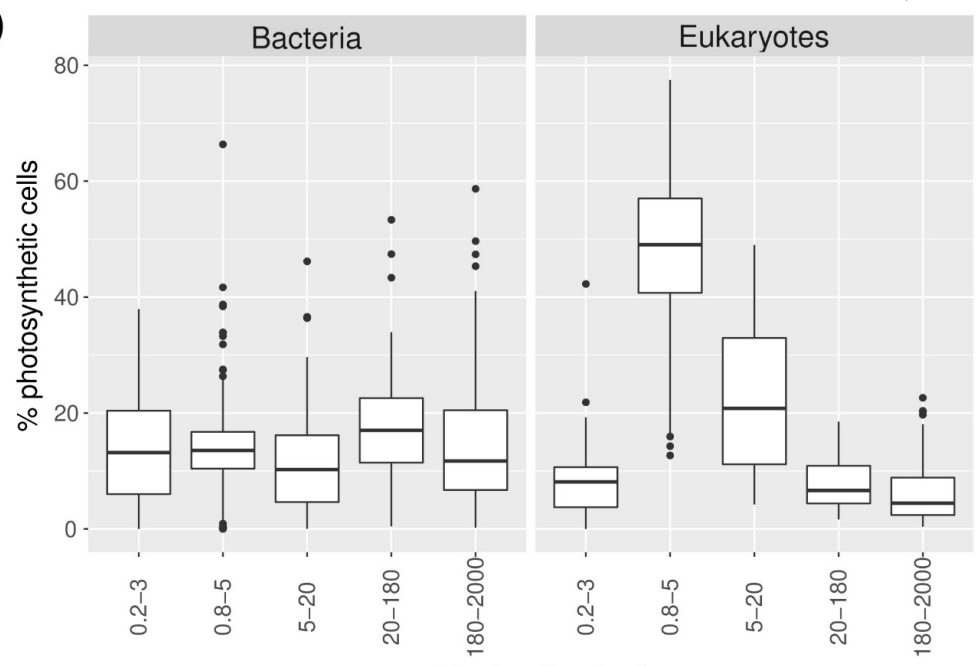

Size fraction $(\mu \mathrm{m})$

Figure 5: Variations in the abundance of phototrophs vs heterotrophs across size fractions. A) Read abundance of V9-18S rRNA gene metabarcoding assigned to dinoflagellates of unknown capacity for photosynthesis. B) Relative abundance of phototrophs among dinoflagellates based on different molecular methods. The first panel corresponds to the trait classification of V9-18S rRNA gene metabarcodes based on the literature (a description of the trait classification can be found at http://taraoceans.sb-roscoff.fr/EukDiv/ and the trait reference database is available at https://zenodo.org/record/3768951\#.YM4odnUzbuE). The second and third panels correspond to the ratio of metagenomic counts of photosynthetic vs housekeeping single-copy nuclear-encoded genes: $p s b O$ vs genes coding for ribosomal proteins, and the genes coding for the Rieske subunits of the Cyt bc-type complexes from chloroplasts and mitochondria (i.e., petC and its mitochondrial homolog). C) Relative abundance of phototrophs among bacterial and eukaryotic plankton across size fractions. The values were determined by the ratio of metagenomic counts of the single-copy marker genes of photosynthesis (i.e., $p s b O$ ) and housekeeping metabolism (i.e., recA for bacteria and genes encoding ribosomal proteins for eukaryotes). 
A)

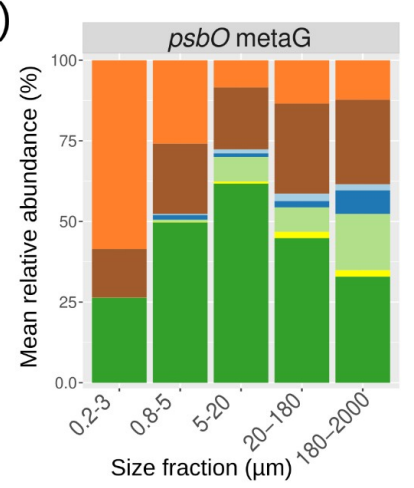

Prochlorococcus Trichodesmium

Synechococcus Other cyanobacteria

Richelia/Calothrix

Crocosphaera

G)
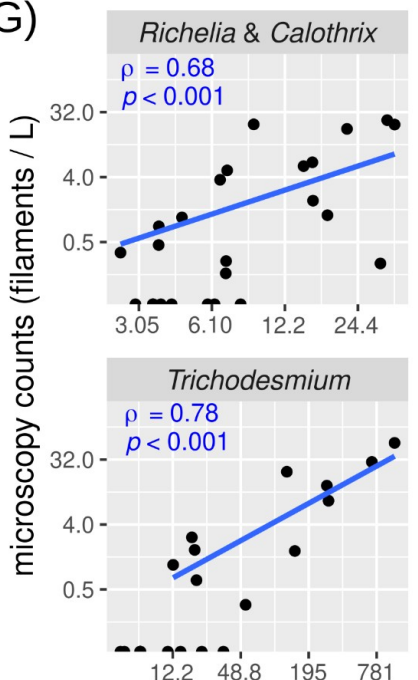

psbO counts $\left(\mathrm{rpkm}{ }^{*} 10^{\wedge} 5\right)$
B)

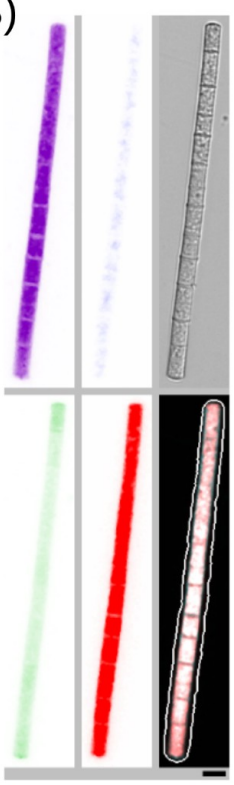

F)
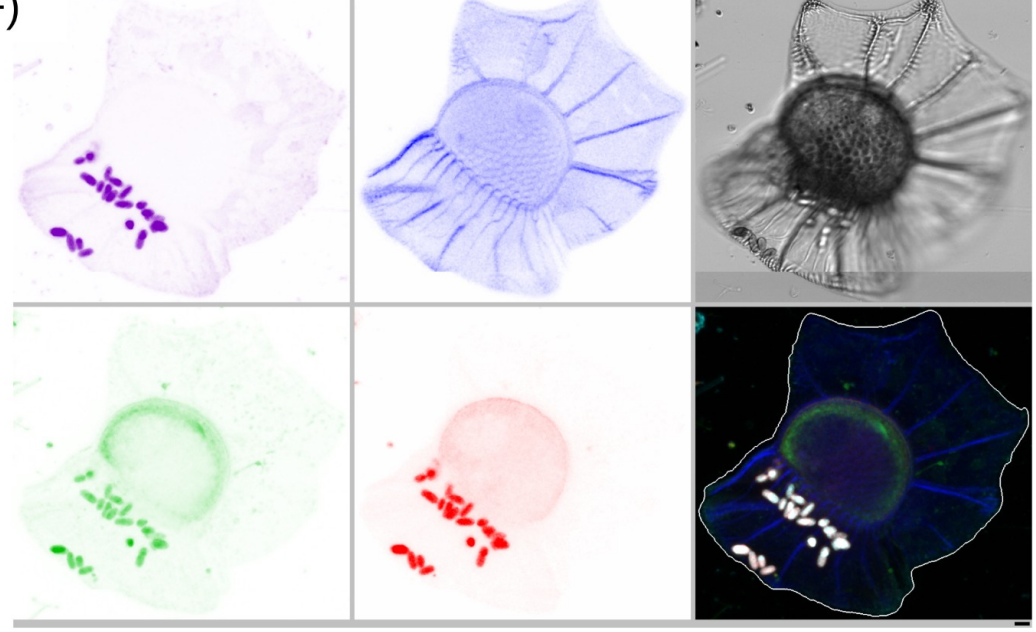

Figure 6: Prokaryotic and eukaryotic phytoplankton community structure across the entire plankton size spectrum. A) Average relative cell abundance of phototrophs across all metagenomes based on $p s b O$ metagenomic reads. (B-F) Examples of confocal microscopy detection of cyanobacteria in the 20-180 $\mu \mathrm{m}$ size fraction. From top left to bottom right, the displayed channels for each micrograph correspond to cell surface (cyan, AlexaFluor 546 dye), DNA (and the theca in dinoflagellates) (blue, Hoechst dye), cellular membranes (green, DiOC6 dye), chlorophyll autofluorescence (red), bright field, and all merged channels. The size bar at the bottom left of each microscopy image corresponds to $2.5 \mu \mathrm{m}$. B) Trichodesmium filament. C) Calothrix filament outside a chain of the diatom Chaetoceros sp. D) Richelia filaments inside the diatom Eucampia cornuta. E) Picocyanobacterial aggregate. F) Picocyanobacterial symbionts in the dinoflagellate Ornithocercus thumii. (G) Correlation analysis between Trichodesmium and Richelia/Calothrix quantifications by confocal microscopy and $p s b O$ metagenomic reads in size fraction 20-180 $\mu \mathrm{m}$. Spearman rho's correlations coefficients and $p$-values are indicated. rpkm: reads per kilobase per million mapped reads. 


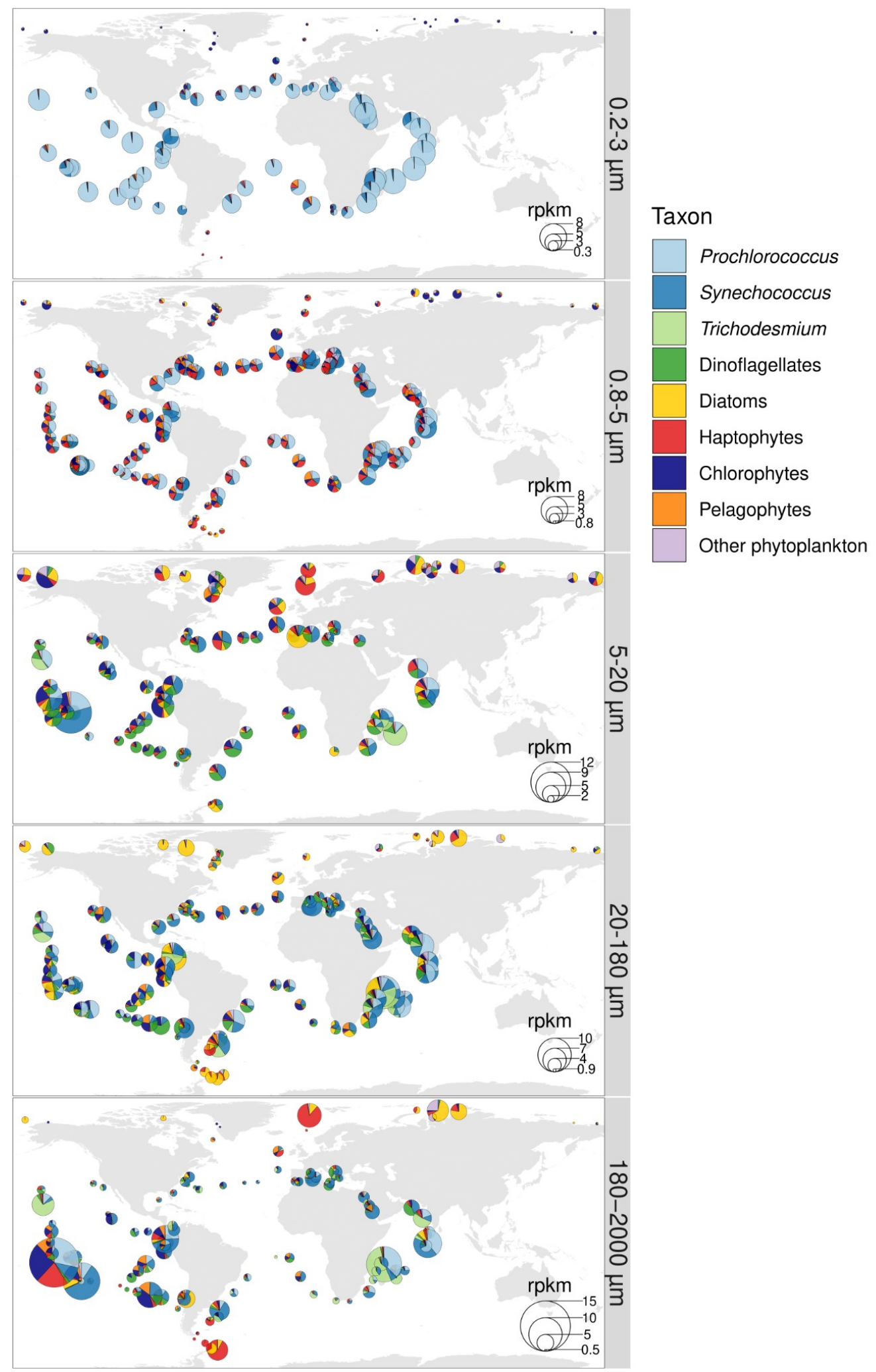

Figure 7: Global biogeographical patterns of marine phytoplankton in surface waters. The pie charts show the $p s b O$ relative abundance of the main cyanobacteria and eukaryotic phytoplankton in metagenomes derived from different size-fractionated samples. Values are displayed as rpkm (reads per kilobase per million mapped reads). The comparison between the psbO-based relative cell abundances versus the patterns corrected by biovolume are displayed in Figure S16. The distribution of the main phytoplankton groups in the size fraction in which they were most prevalent is shown in Figure S17. 


\section{psbO reference database}

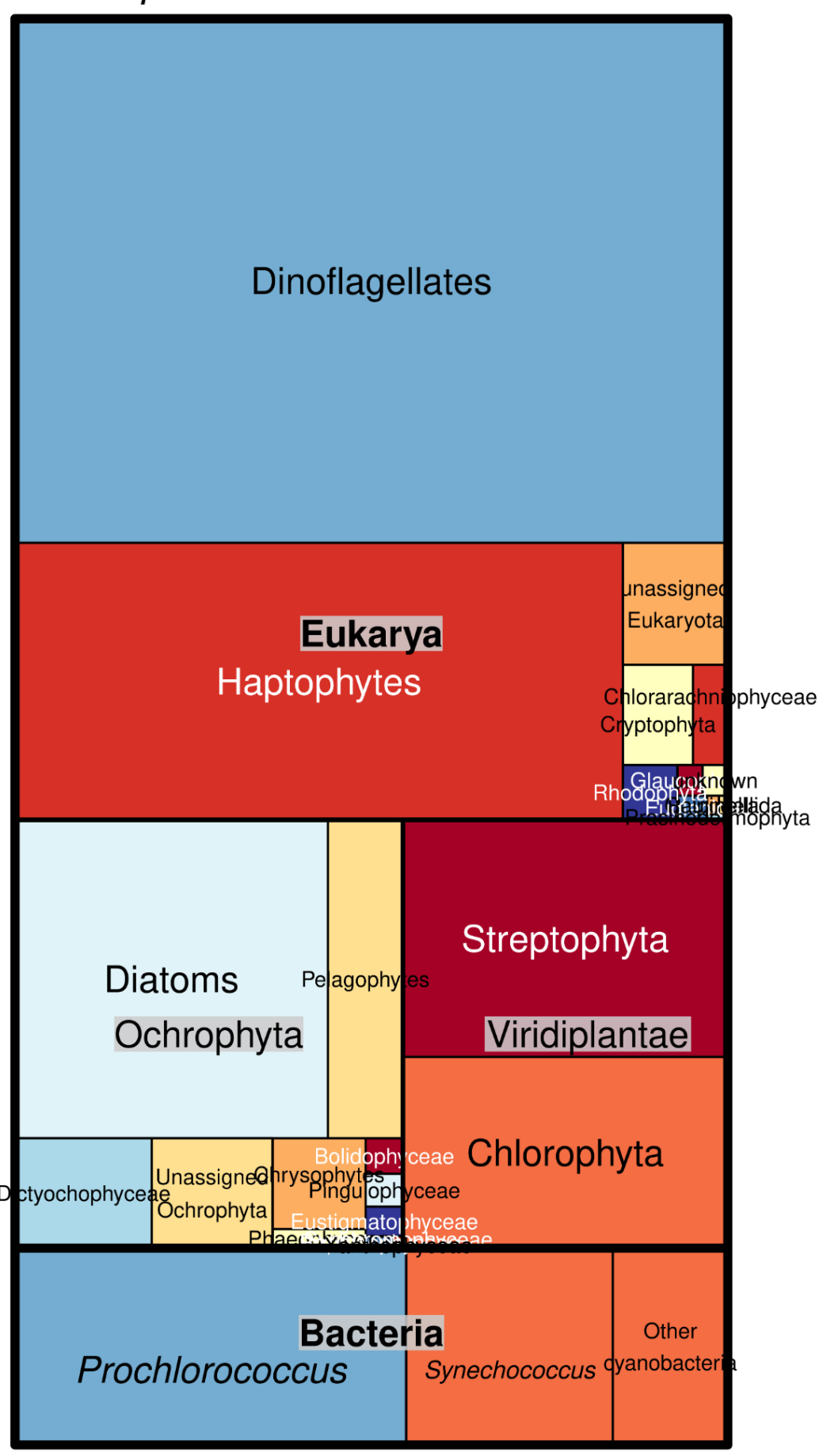

Figure S1: Taxonomic distribution of the curated $p s b O$ database generated in the current work. It consists of 18,378 unique sequences covering cyanobacteria, photosynthetic protists, macroalgae and land plants. The sequences were retrieved from sequenced genomes and transcriptomes from cultured isolates as well as from the environmental sequence catalogs of Global Ocean Sampling (Rusch et al. 2007) and Tara Oceans (Salazar et al. 2019; Carradec et al. 2018; Delmont et al. 2020; 2021). The database can be downloaded from the EMBL-EBI repository BioStudies (www.ebi.ac.uk/biostudies) under accession S-BSST659. 
bioRxiv preprint doi: https://doi.org/10.1101/2021.05.28.446125; this version posted September 19, 2021. The copyright holder for this preprint (which was not certified by peer review) is the author/funder, who has granted bioRxiv a license to display the preprint in perpetuity. It is made available under aCC-BY 4.0 International license.

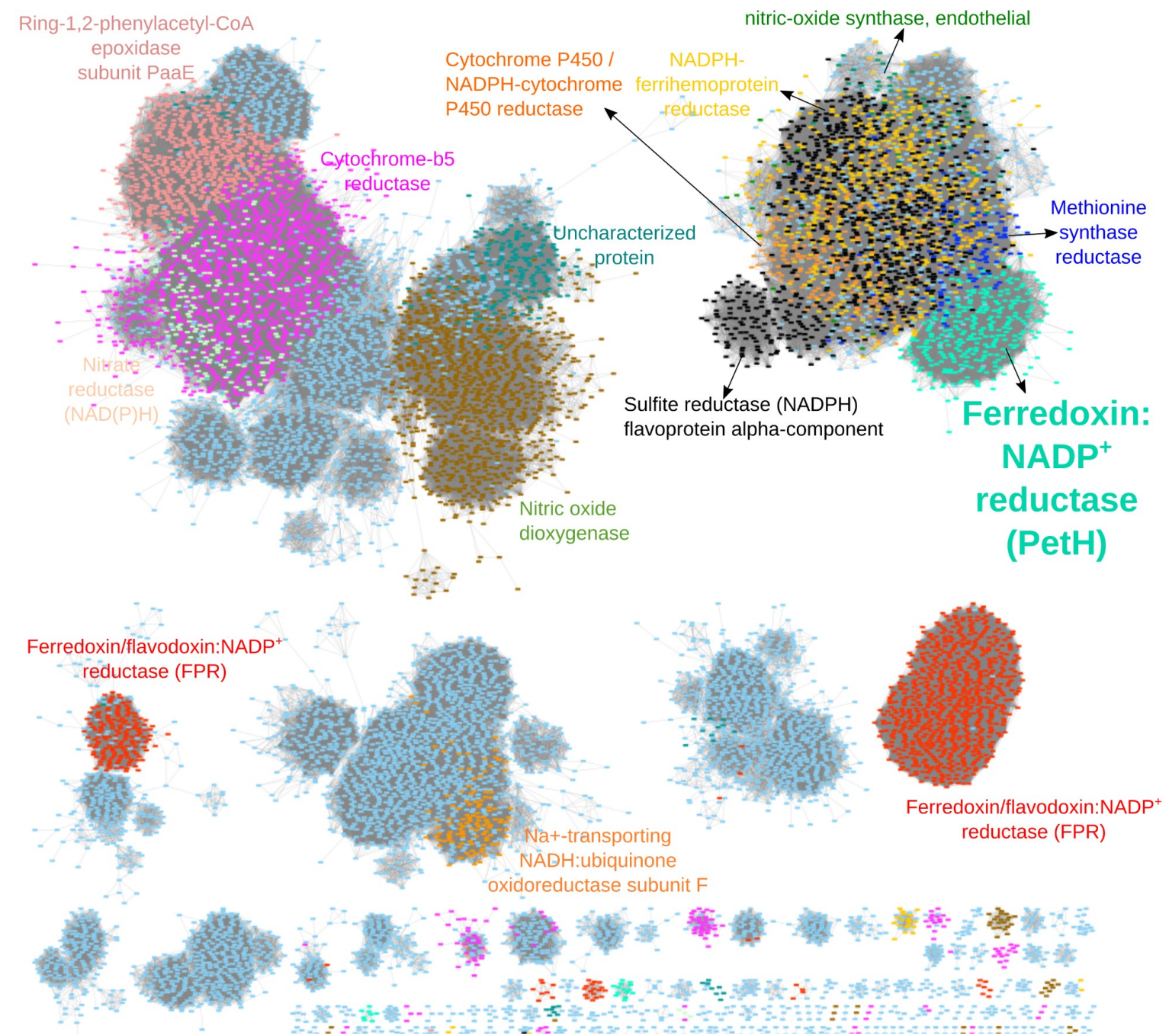

Figure S2: Sequence analysis of ferredoxin:NADP ${ }^{+}$reductase $(\mathrm{PetH})$ and homologs. Protein similarity network for the Pfam domain NAD_binding_1 (PF00175). Each node corresponds to a representative sequence (clustered at $80 \%$ identity by $\mathrm{C} \overline{\mathrm{D} H I T}$ ) and those sequences with similarity higher than a score cutoff are linked (score cut-off of 22 in blastp alignment). The network was built with sequences retrieved from the literature and from reference genomes and transcriptomes. Nodes are coloured according to their functional assignment based on BlastKOALA. The nodes for FNR are in light green, and includes photosynthetic FNRs as well as FNRs involved in nitrogen metabolism and in nonphotosynthetic plastids (Pierella Karlusich \& Carrillo 2017 Phot Res 134:235-250) and FNR from heterotrophic bacteria acquired by horizontal gene transfer (Catalano Dupuy et al. 2011 PLoS One 6:e26736).. 
bioRxiv preprint doi: https://doi.org/10.1101/2021.05.28.446125; this version posted September 19, 2021. The copyright holder for this preprint (which was not certified by peer review) is the author/funder, who has granted bioRxiv a license to display the preprint in perpetuity. It is made available under aCC-BY 4.0 International license.

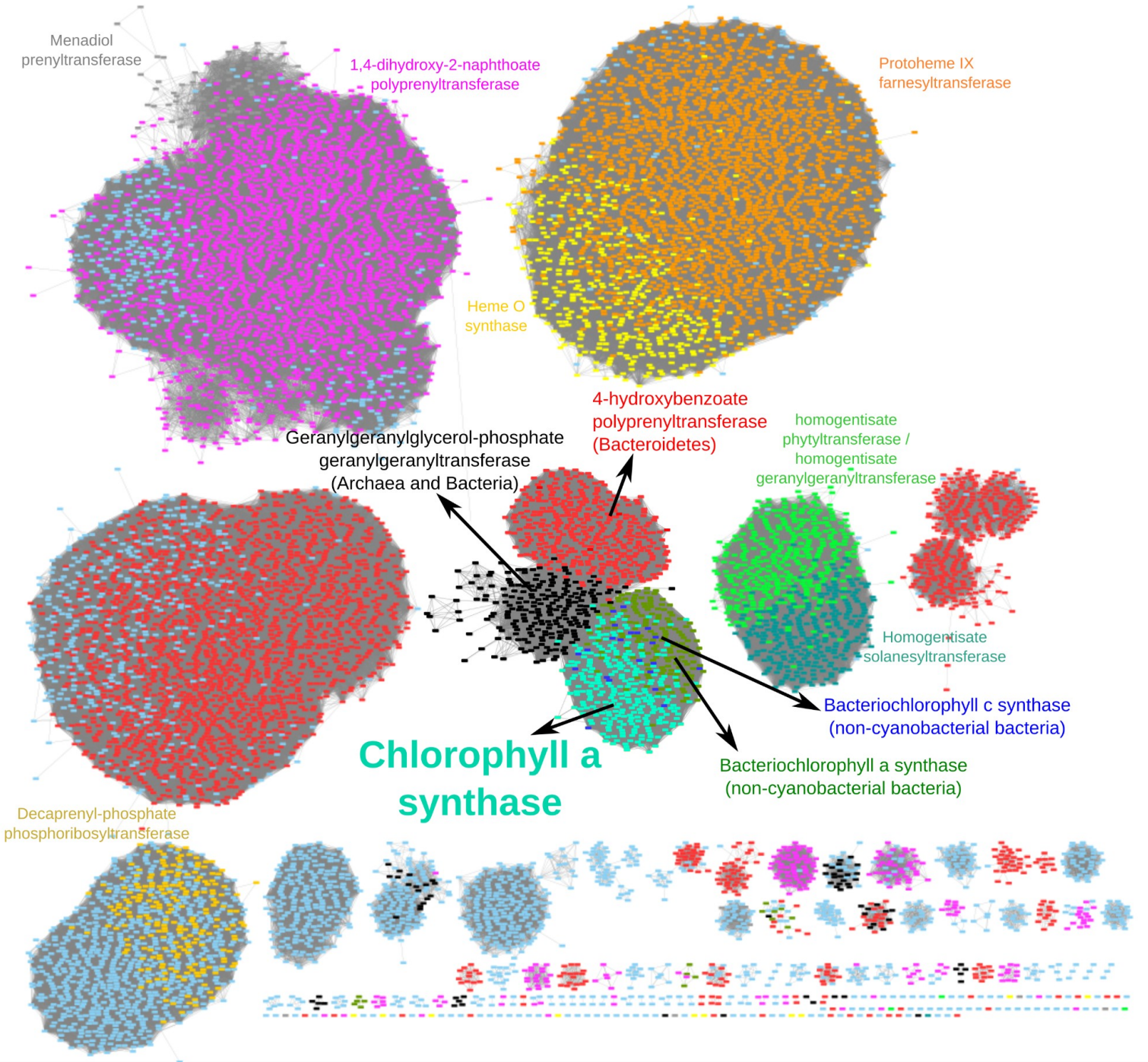

Figure S3: Sequence analysis of chlorophyll a synthase (ChIG) and homologs. Protein similarity network for the Pfam domain UbiA (PF01040). Each node corresponds to a representative sequence (clustered at $80 \%$ identity by CDHIT) and those sequences with similarity higher than a score cutoff are linked (score cut-off of 25 in blastp alignment). The network was built with sequences retrieved from the literature and from reference genomes and transcriptomes. Nodes are coloured according to their functional assignment based on BlastKOALA. 
bioRxiv preprint doi: https://doi.org/10.1101/2021.05.28.446125; this version posted September 19, 2021. The copyright holder for this preprint (which was not certified by peer review) is the author/funder, who has granted bioRxiv a license to display the preprint in perpetuity. It is made available under aCC-BY 4.0 International license.

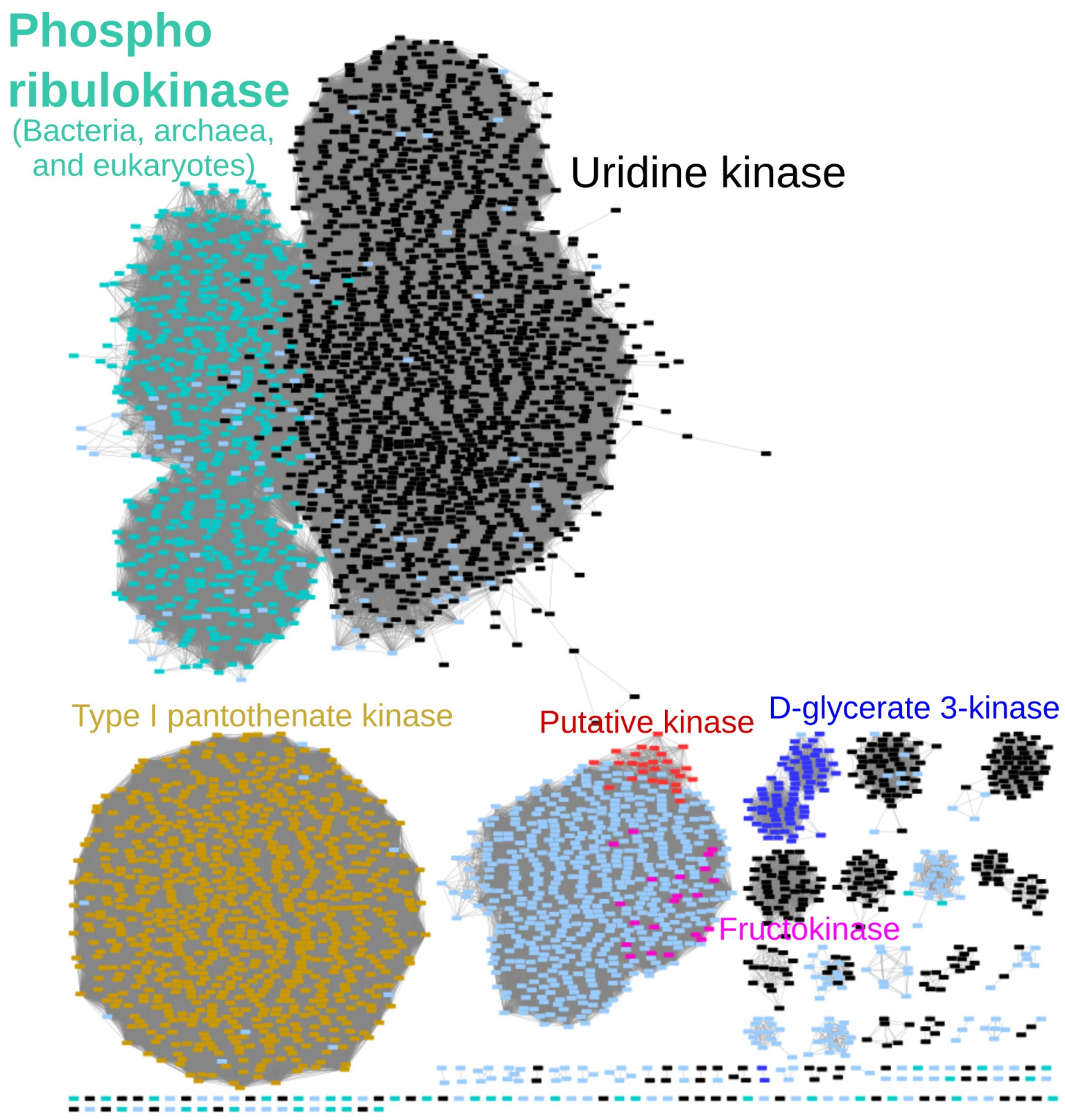

Figure S4: Sequence analysis of phosphoribulokinase (PRK) and homologs. Protein similarity network for the Pfam domain PRK (PF00485). Each node corresponds to a representative sequence (clustered at $80 \%$ identity by CDHIT) and those sequences with similarity higher than a score cutoff are linked (score cut-off of 25 in blastp alignment). The network was built with sequences retrieved from the literature and from reference genomes and transcriptomes. Nodes are coloured according to their functional assignment based on BlastKOALA. The nodes for PRK are in light green, and include photosynthetic PRKs as well as those from archaea and non-cyanobacterial bacteria. 
bioRxiv preprint doi: $\mathrm{https}$ ://doi org/10.1101/2021.05.28.446125; this version posted September 19, 2021. The copyright holder for this preprint (which was not certified by peer review) is the author/funder, who has granted bioRxiv a license to display the preprint in perpetuity. It is made available under aCC-BY 4.0 International license.

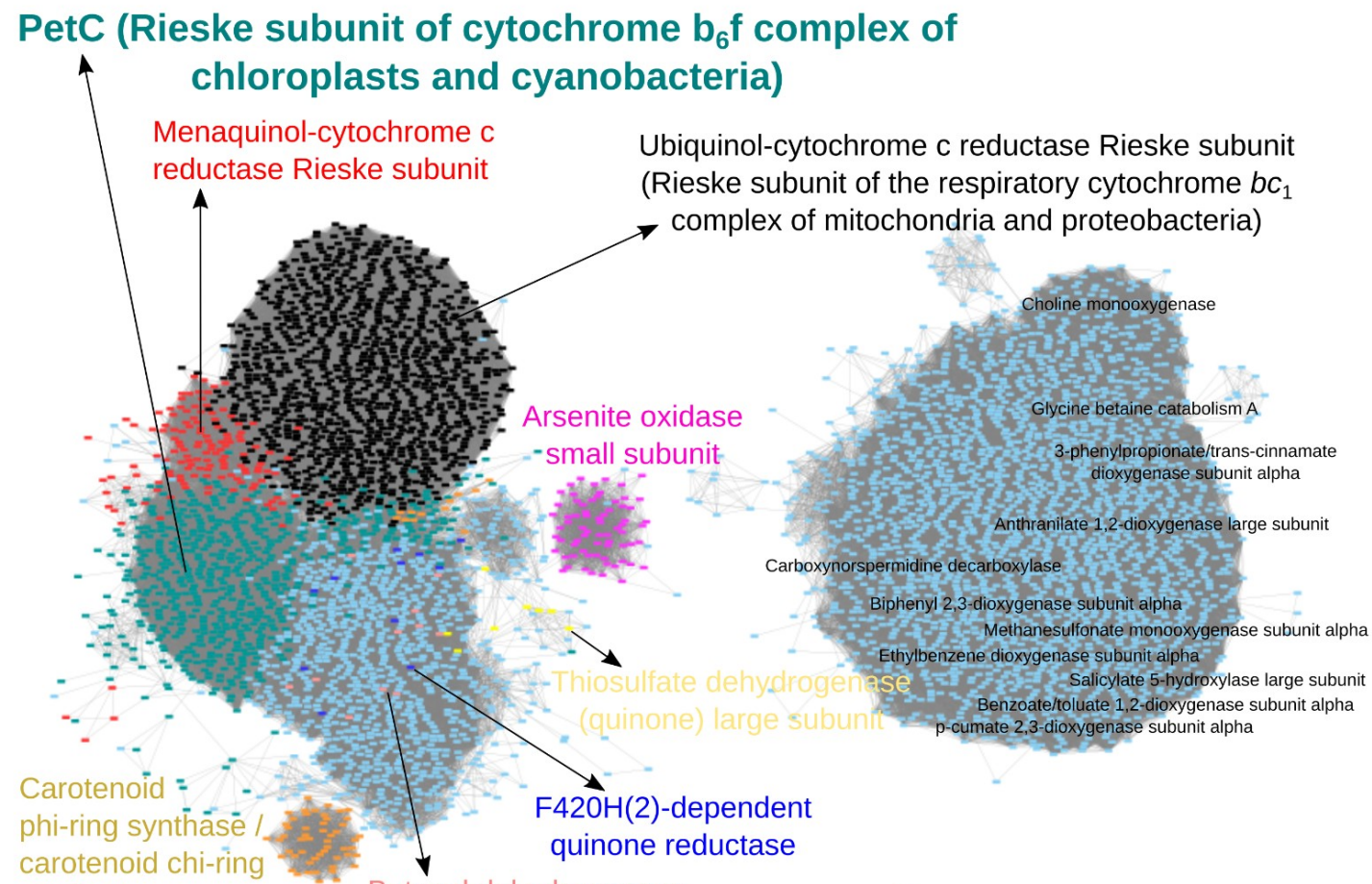

synthase Butanol dehydrogenase

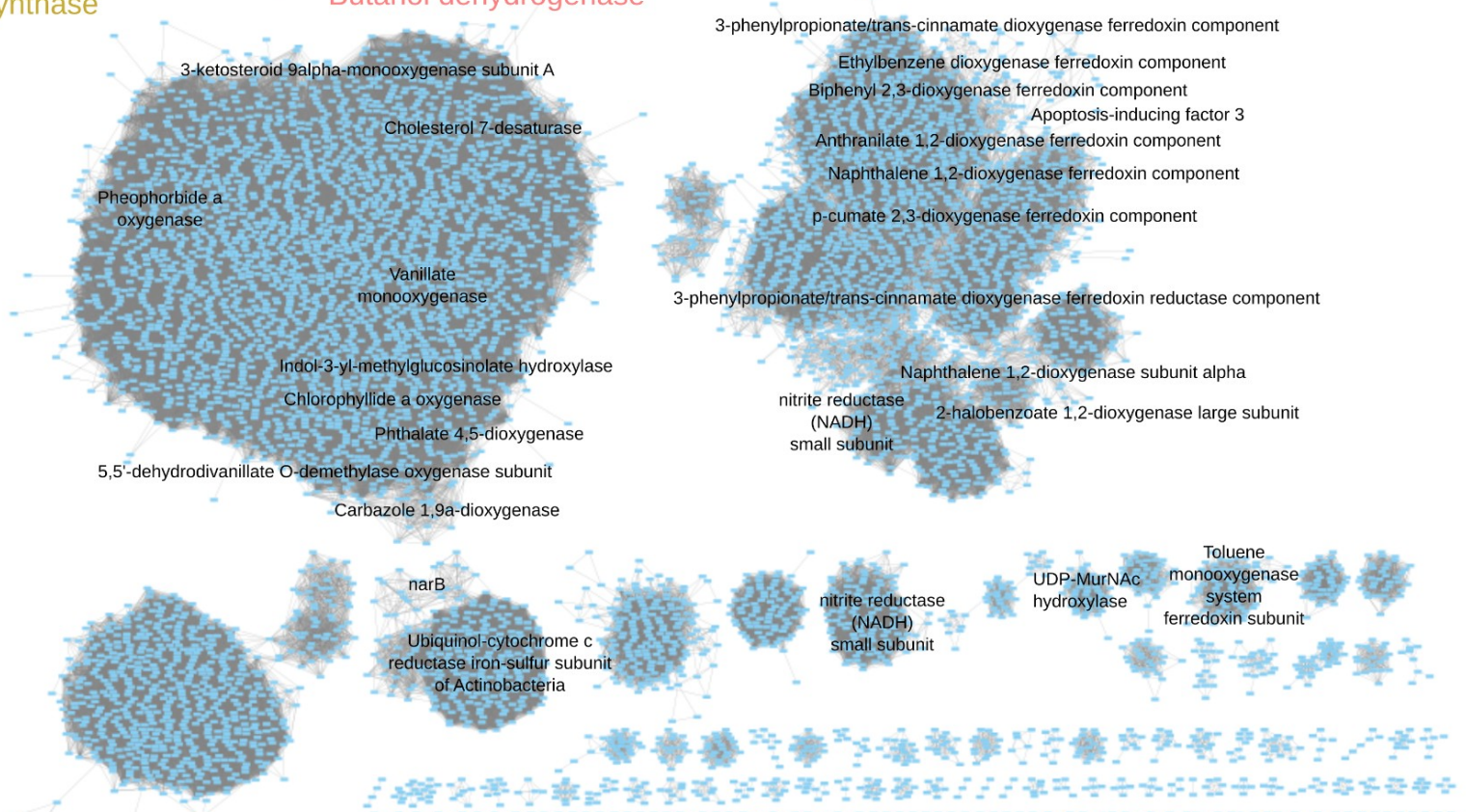

Figure S5: Sequence analysis of PetC (Rieske subunit of the Cytochrome $b_{6} f$ complex) and homologs. Protein similarity network for the Pfam domain Rieske (PF00355). Each node corresponds to a representative sequence (clustered at $80 \%$ identity by CDHIT) and those sequences with similarity higher than a score cutoff are linked (score cut-off of 18 in blastp alignment). The network was built with sequences retrieved from the literature and from reference genomes and transcriptomes. Labels correspond to the functional assignment based on BlastKOALA, and for the cluster of interest nodes are coloured according to the functional assignment of their sequences. The nodes for PetC are in green and those for the Rieske subunit of the respiratory Cytochrome $b c_{1}$ complex are in black. 
bioRxiv preprint doi: $\mathrm{https}: / /$ doi.org/10.1101/2021.05.28.446125; this version posted September 19, 2021. The copyright holder for this preprint (which was not certified by peer review) is the author/funder, who has granted bioRxiv a license to display the preprint in perpetuity. It is made available under aCC-BY 4.0 International license.

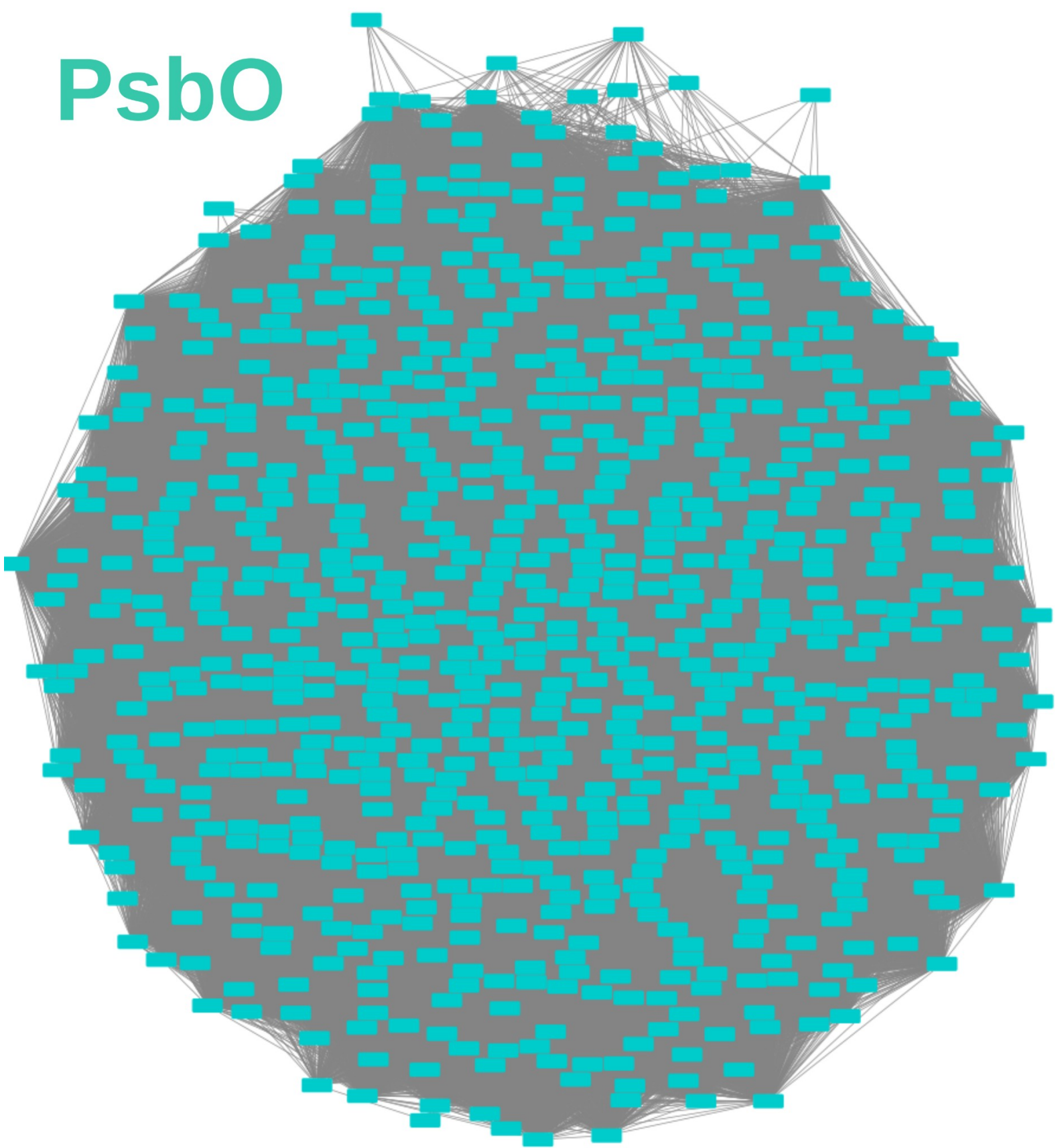

Figure S6: Sequence analysis of PsbO protein. Protein similarity network for the Pfam domain MSP (PF01716). Each node corresponds to a representative sequence (clustered at $80 \%$ identity by CDHIT) and those sequences with similarity higher than a score cutoff are linked (score cut-off of 30 in blastp alignment). The network was built with sequences retrieved from the literature and from reference genomes and transcriptomes. Nodes are coloured according to their functional assignment based on BlastKOALA. 

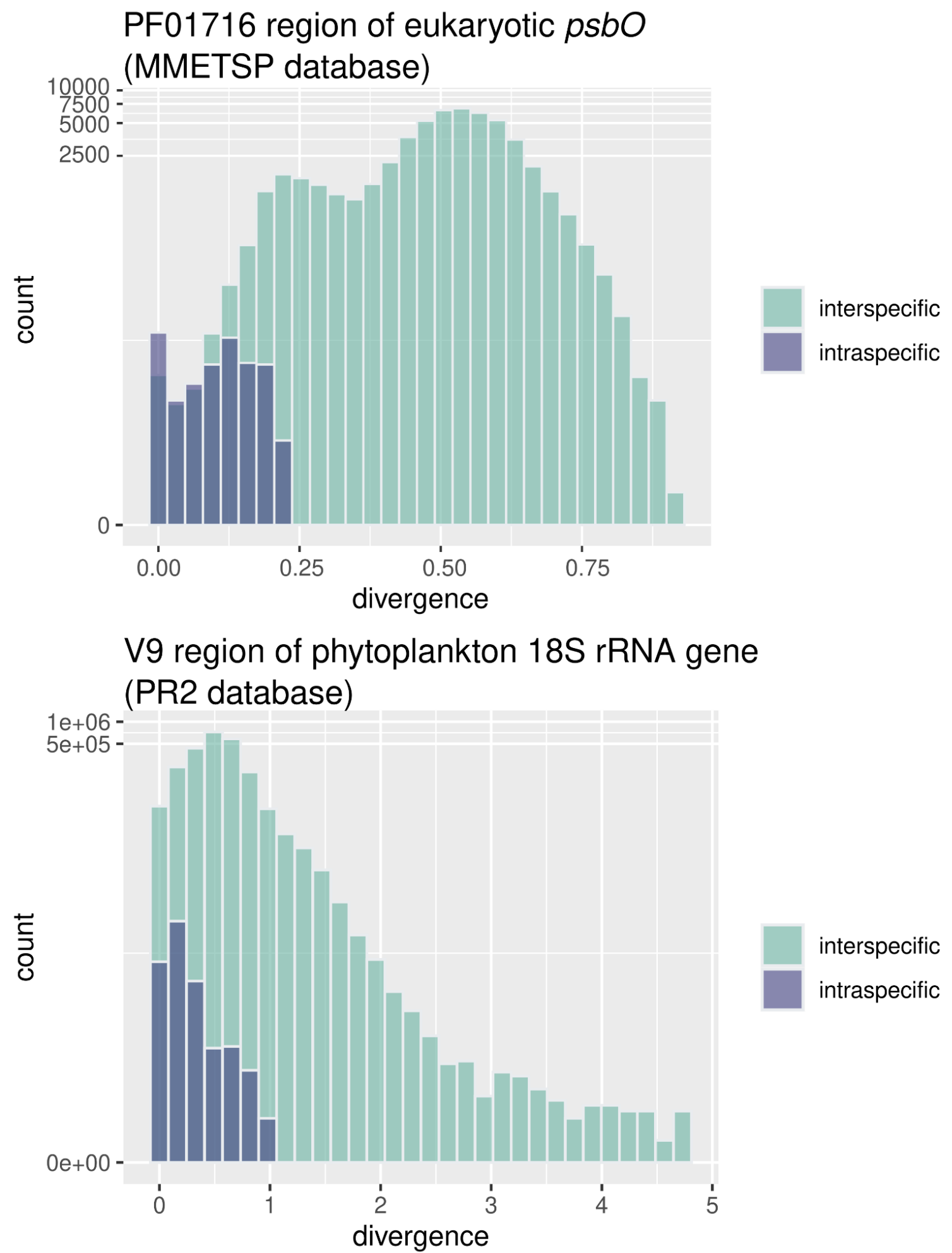

Figure S7: Intraspecific (blue) and interspecific (green) variation in genetic distances of eukaryotic phytoplankton sequences for the region of $p s b O$ coding for the Pfam domain PF01716 (upper panel) and the V9 region of 18S rRNA gene (lower panel). Sequences were retrieved from MMETSP project (Keeling et al. 2014) for psbO and from PR2 database (Guillou et al. 2012) for V9-18S maker. In this later case, the sequence assigned to phytoplankton were selected based on a public functional database available at https://zenodo.org/record/3768951\#.YM4odnUzbuE. 
bioRxiv preprint doi: https://doi.org/10.1101/2021.05.28.446125; this version posted September 19, 2021. The copyright holder for this preprint (which was not certified by peer review) is the author/funder, who has granted bioRxiv a license to display the preprint in perpetuity. It is made available under aCC-BY 4.0 International license.

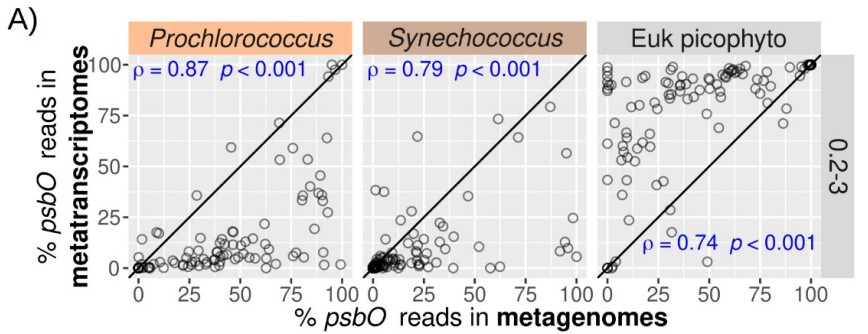

B)

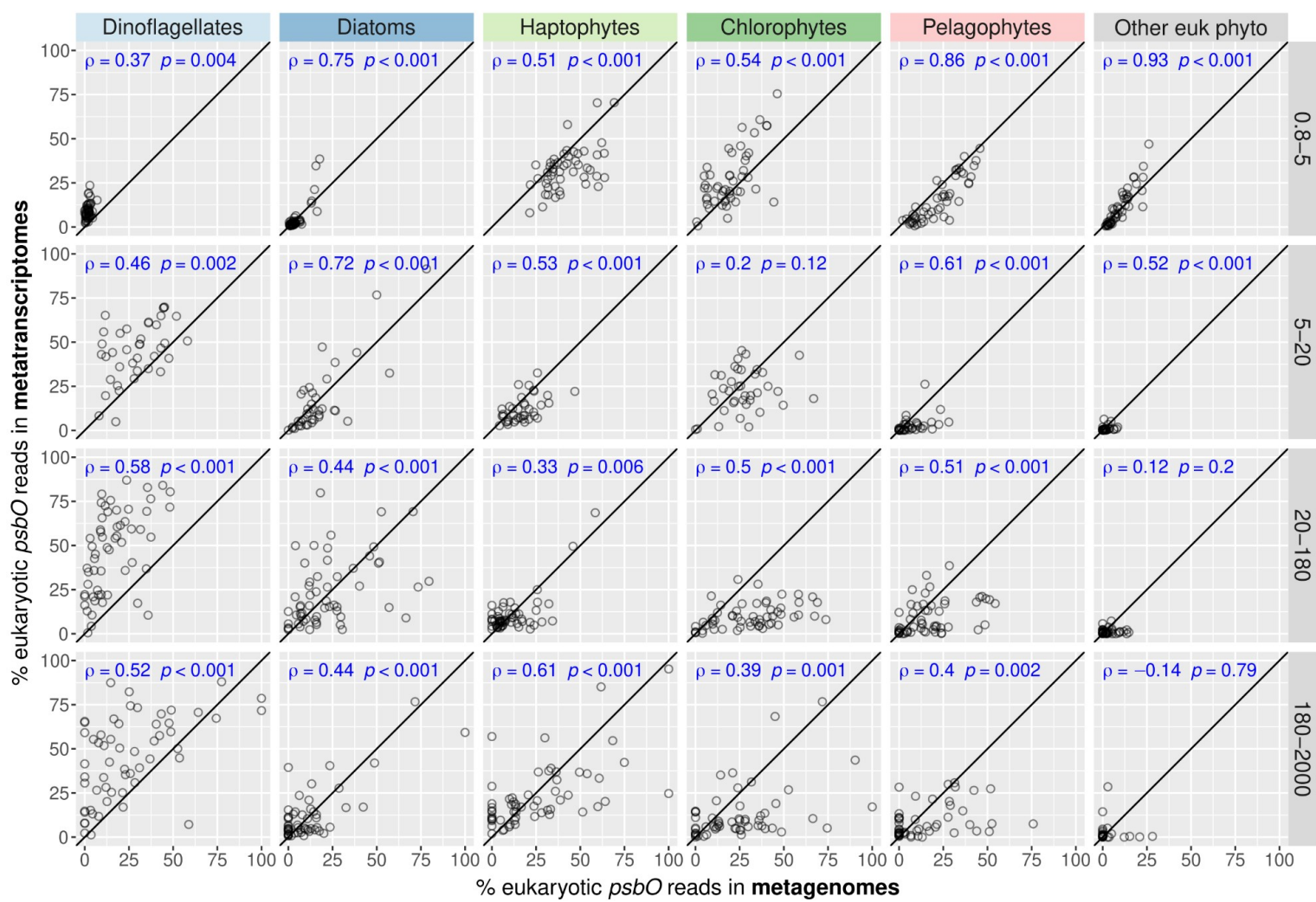

Figure S8: Comparison of relative abundances of psbO reads between metagenomes and metatranscriptomes of size fractionated samples. A) Picocyanobacteria and eukaryotic picophytoplankton (size fraction 0.2-3 $\mu \mathrm{m}$ ). B) Eukaryotic phytoplankton in the large size fractions (0.8$5 \mu \mathrm{m}, 5-20 \mu \mathrm{m}, 20-180 \mu \mathrm{m}, 180-2000 \mu \mathrm{m})$, with metagenomes compared to metatranscriptomes derived from poly-A RNA. Axis are in the same scale and the diagonal line corresponds to a 1:1 slope. Spearman's rho correlation coefficients and $p$-values are displayed in blue. 
bioRxiv preprint doi: https://doi org/10.1101/2021.05.28,446125; this version posted September 19, 2021. The copyright holder for this preprint (which was not certified by peer review) is the author/funder, who has granted bioRxiv a license to display the preprint in perpetuity. It is made available under aCC-BY 4.0 International license.

A)

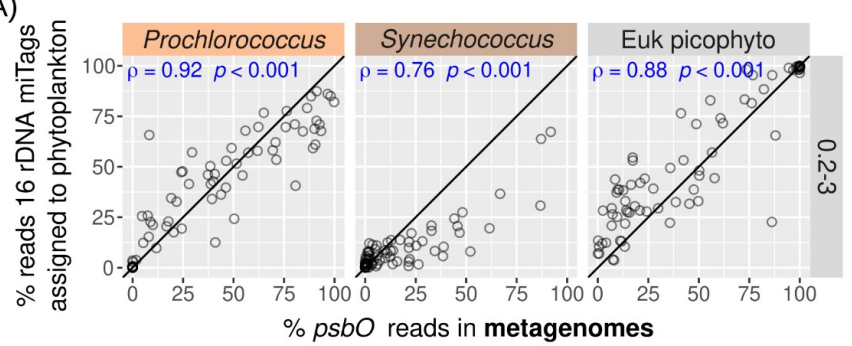

B)

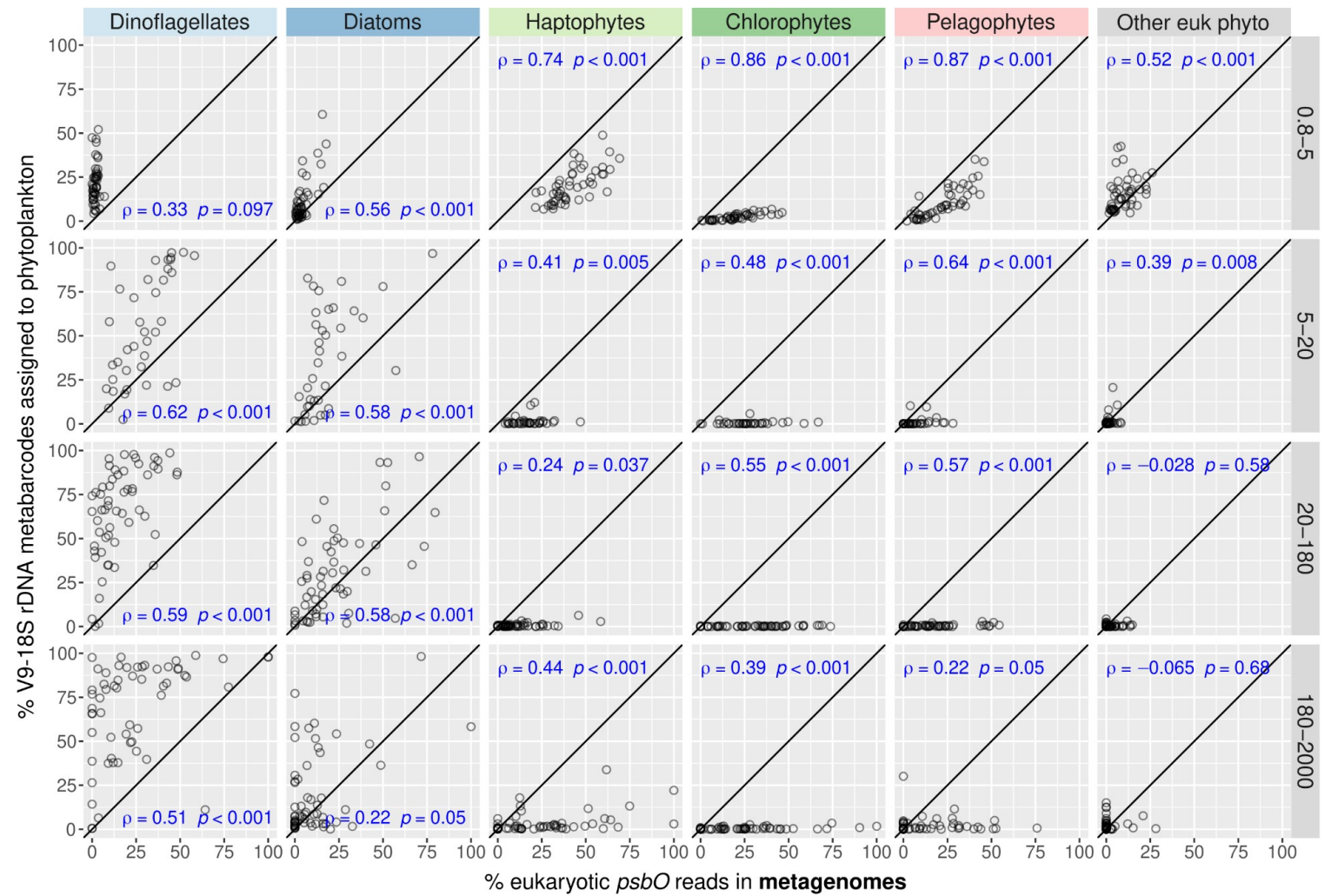

Figure 59: Comparison of relative read abundances of psbO and rRNA genes of size

fractionated samples. A) Picocyanobacteria and eukaryotic picophytoplankton $(0.2-3 \mu \mathrm{m})$ were analysed using the relative abundances for $16 \mathrm{~S}$ rRNA gene miTags and for $p s b O$ metagenomic reads. B) Eukaryotic phytoplankton were analysed in the large size fractions $(0.8-5 \mu \mathrm{m}, 5-20 \mu \mathrm{m}, 20-180 \mu \mathrm{m}$, 180-2000 $\mu \mathrm{m}$ ) using the relative abundances for V9-18S rRNA gene amplicons and psbO Spearman's rho correlation coefficients and $p$-values are displayed in blue. 


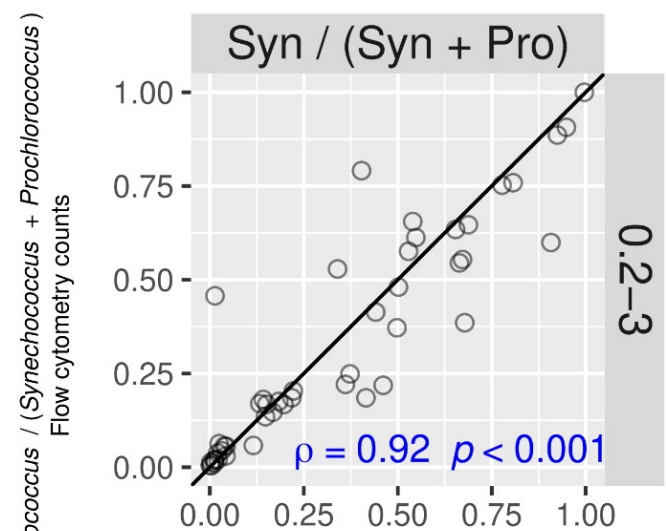

Synechococcus / (Synechococcus + Prochlorococcus) psbO metagenomic reads

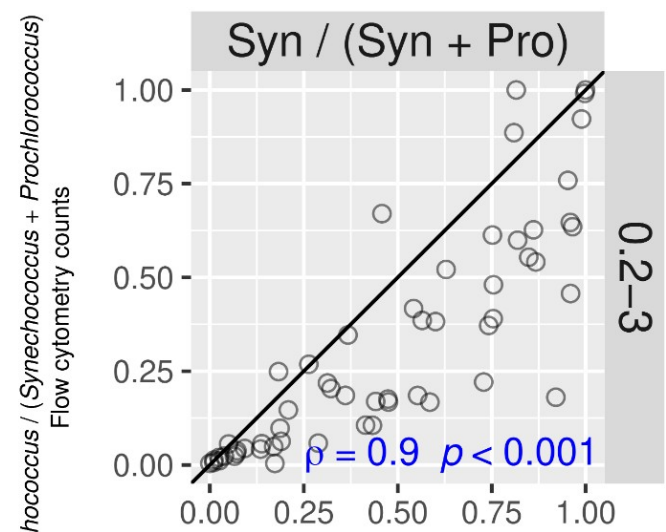

Synechococcus / (Synechococcus + Prochlorococcus) psbO metatranscriptomic reads

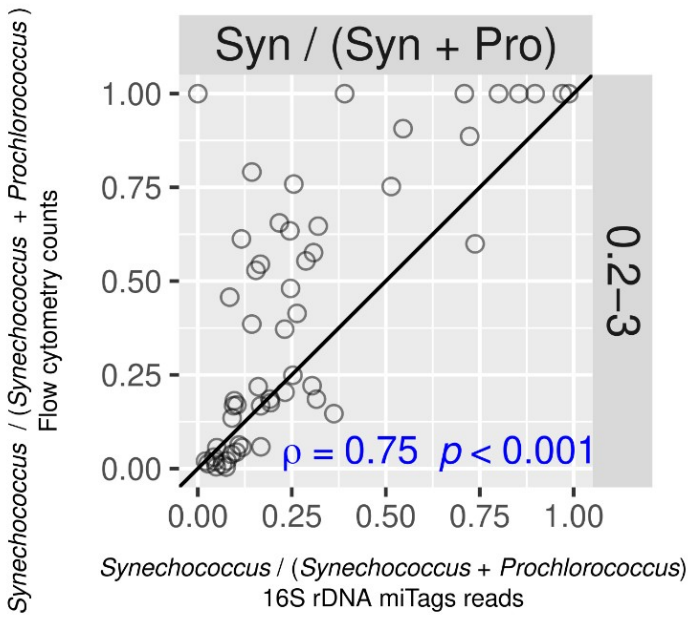




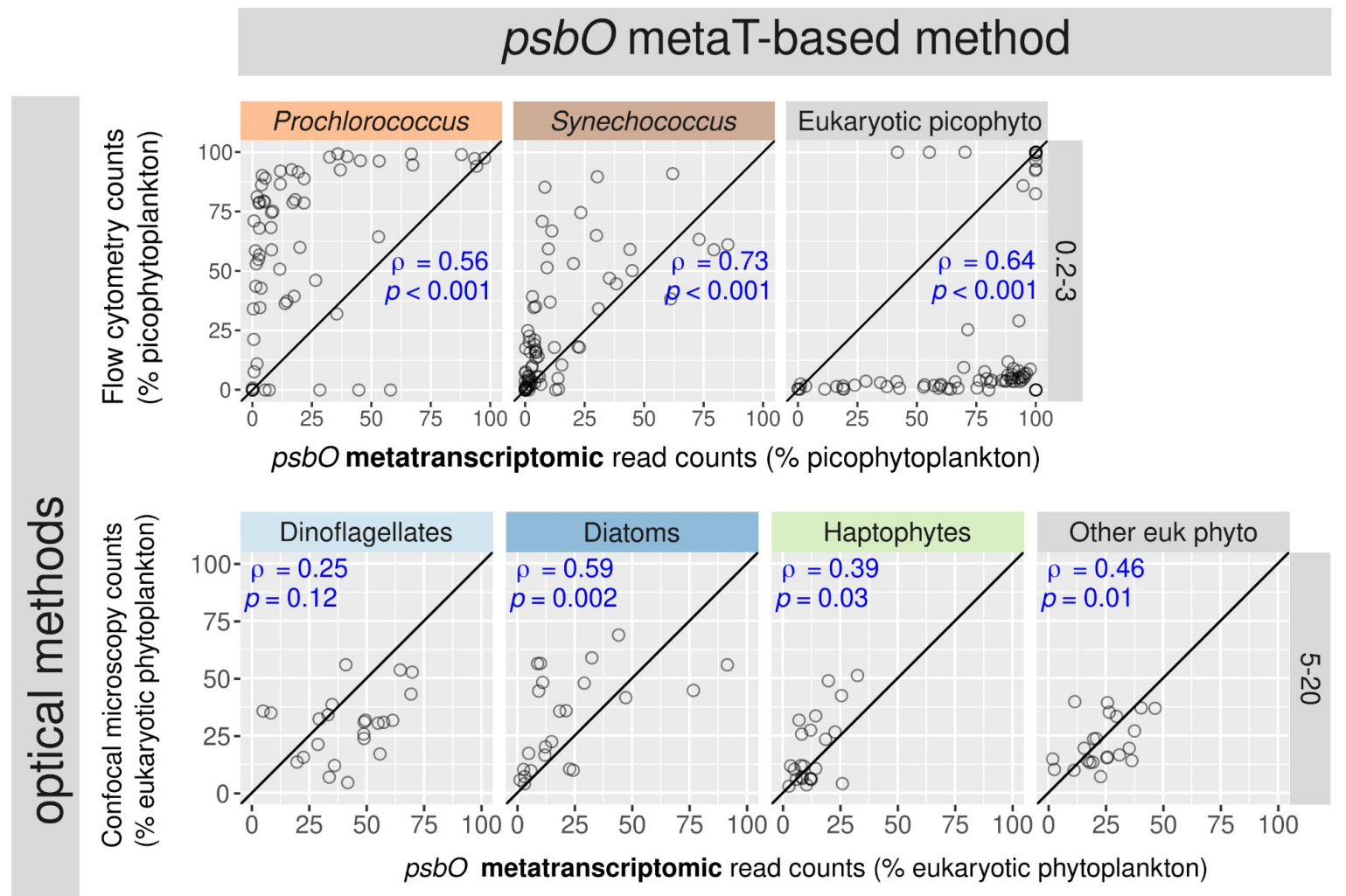

1403
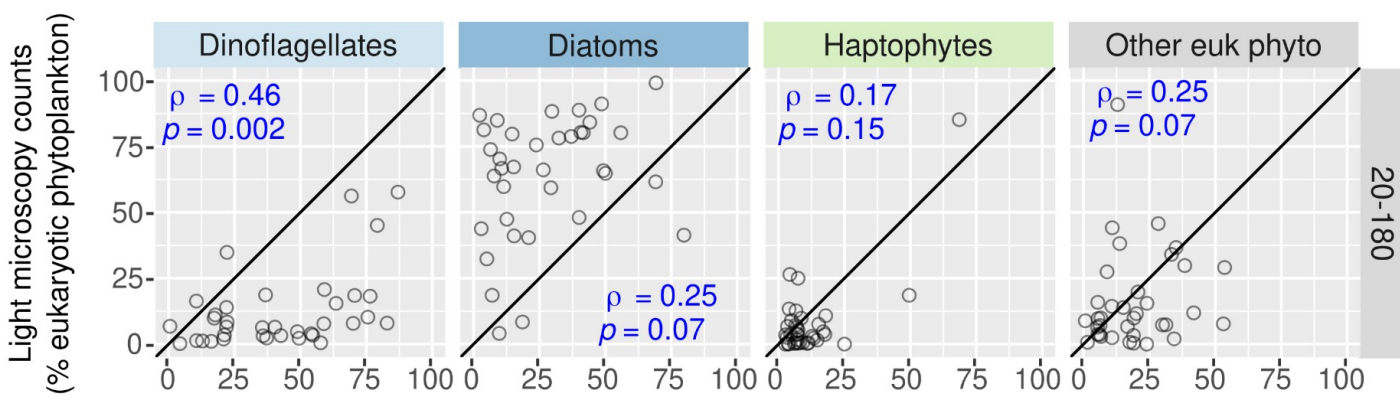

psbO metatranscriptomic read counts (\% eukaryotic phytoplankton)

Figure S11: Correlation between relative abundances based on psbO metatranscriptomic reads against those based on optical quantifications of different phytoplankton groups. Upper panel: metatranscriptomic $p s b O$ relative abundances from picophytoplankton (size fraction 0.2-3 $\mu \mathrm{m}$ ) were compared with flow cytometry counts (values displayed as \% total abundance of picophytoplankton). Middle and lower panels: metatranscriptomic $p s b O$ relative abundances of eukaryotic phytoplankton were compared with confocal microscopy counts from size fraction 5-20 $\mu \mathrm{m}$ and light microscopy counts from size fraction 20-180 $\mu \mathrm{m}$ (values displayed as \% total abundance of eukaryotic phytoplankton). Spearman correlation coefficients and p-values are displayed in blue. Axis are in the same scale and the diagonal line corresponds to a 1:1 slope. 


\section{psbO metaT-based method}
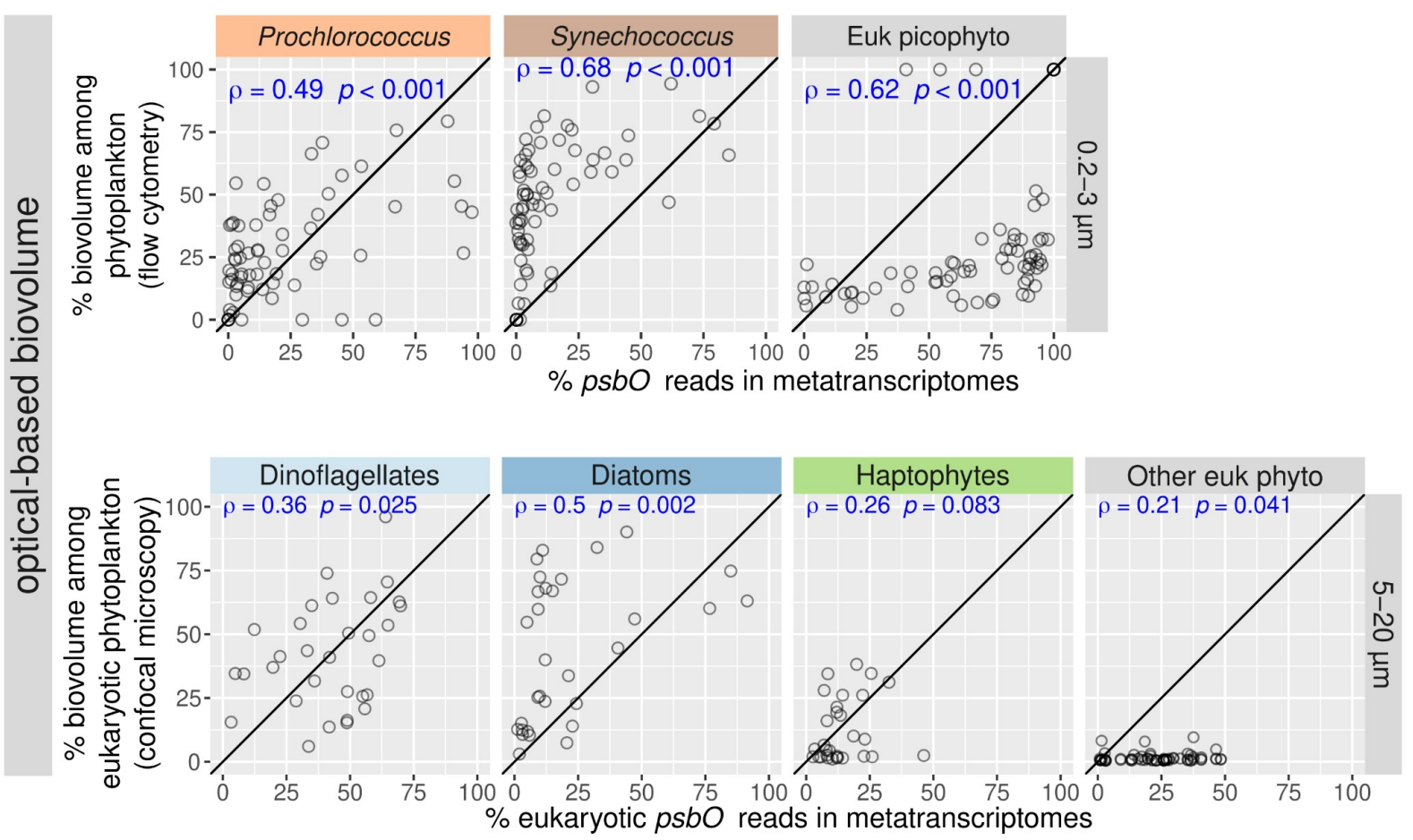

Figure S12: Correlation between relative biovolume (based on optical methods) and relative abundances based on psbO metatranscriptomic reads. The upper panel shows the correlations for picophytoplankton (size fraction 0.2-3 $\mu \mathrm{m}$ ). The vertical axis corresponds to the relative biovolume based on flow cytometry (values displayed as \% total biovolume of picophytoplankton), while the horizontal axis corresponds to relative read abundance based on $p s b O$ metatranscriptomic reads. The lower panel shows the correlations for nanophytoplankton (size fraction 5-20 $\mu \mathrm{m}$ ). The vertical axis corresponds to the relative biovolume based on confocal microscopy quantification (values displayed as \% total abundance of eukaryotic phytoplankton), while the horizontal axis corresponds to relative read abundance based on eukaryotic $p s b O$ metatranscriptomic reads. Spearman correlation coefficients and p-values are displayed in blue. Axis are in the same scale and the diagonal line corresponds to a 1:1 slope. 
bioRxiv preprint doi: https:/doi org/10.1101/2021.05.28,446125; this version posted September 19, 2021. The copyright holder for this preprint (which was not certified by peer review) is the author/funder, who has granted bioRxiv a license to display the preprint in perpetuity. It is made available under aCC-BY 4.0 International license.

Photosynthetic dinoflagellates (V9-18S)
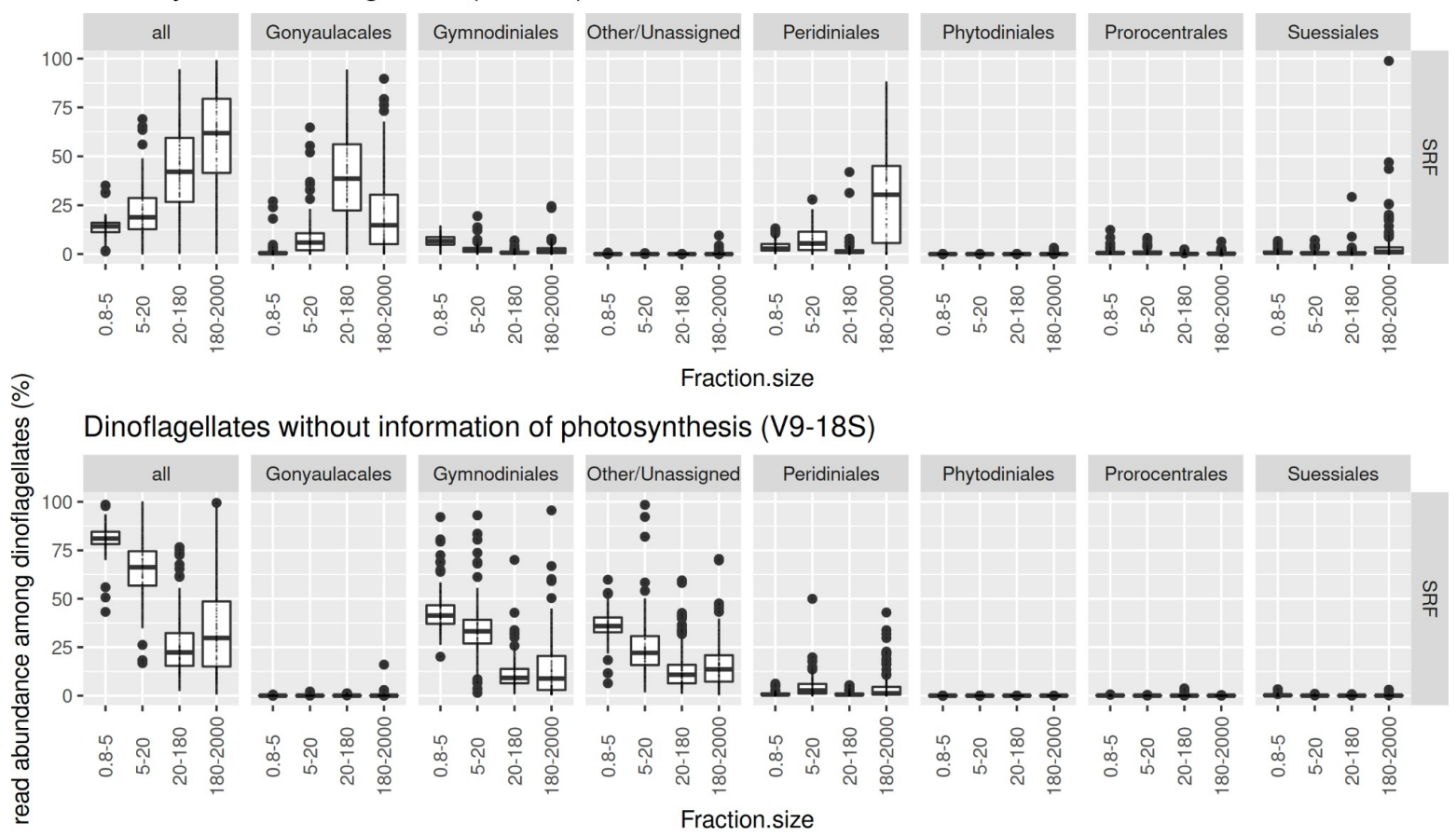

Non-photosynthetic dinoflagellates (V9-18S)
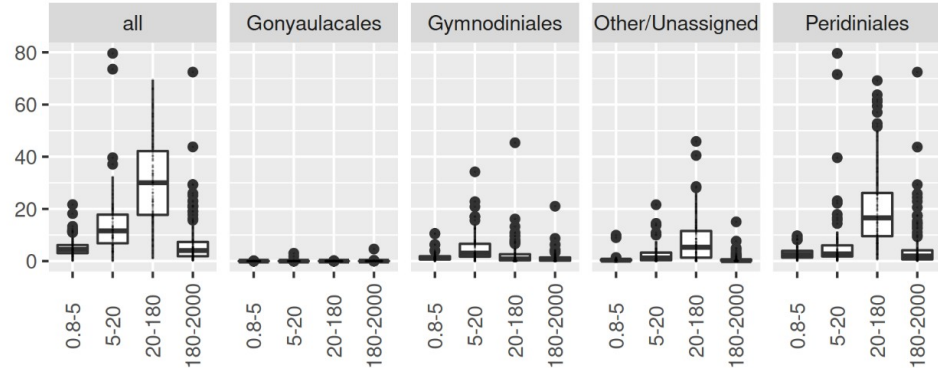

Phytodiniales

Prorocentrales

Suessiales

Fraction.size

Figure S13: Variations in the abundance of phototrophs vs heterotrophs in the dinoflagellate show the relative abundance of dinoflagellates containing chloroplasts (upper panel) or not (lower panel) as well as those that cannot be classified (middle panel). Note that most of the reads that cannot be reliably classified as a chloroplast-containing taxon correspond to those reads mapping OTUs assigned either as "unknown dinoflagellate" or Gymnodiales order. A description of the trait classification can be found at http://taraoceans.sb-roscoff.fr/EukDiv/ and the trait reference database is available at https://zenodo.org/record/3768951\#.YM4odnUzbuE. 
bioRxiv preprint doi: https://doi.org/10.1101/2021.05.28.446125; this version posted September 19, 2021. The copyright holder for this preprint (which was not certified by peer review) is the author/funder, who has granted bioRxiv a license to display the preprint in perpetuity. It is made available under aCC-BY 4.0 International license.

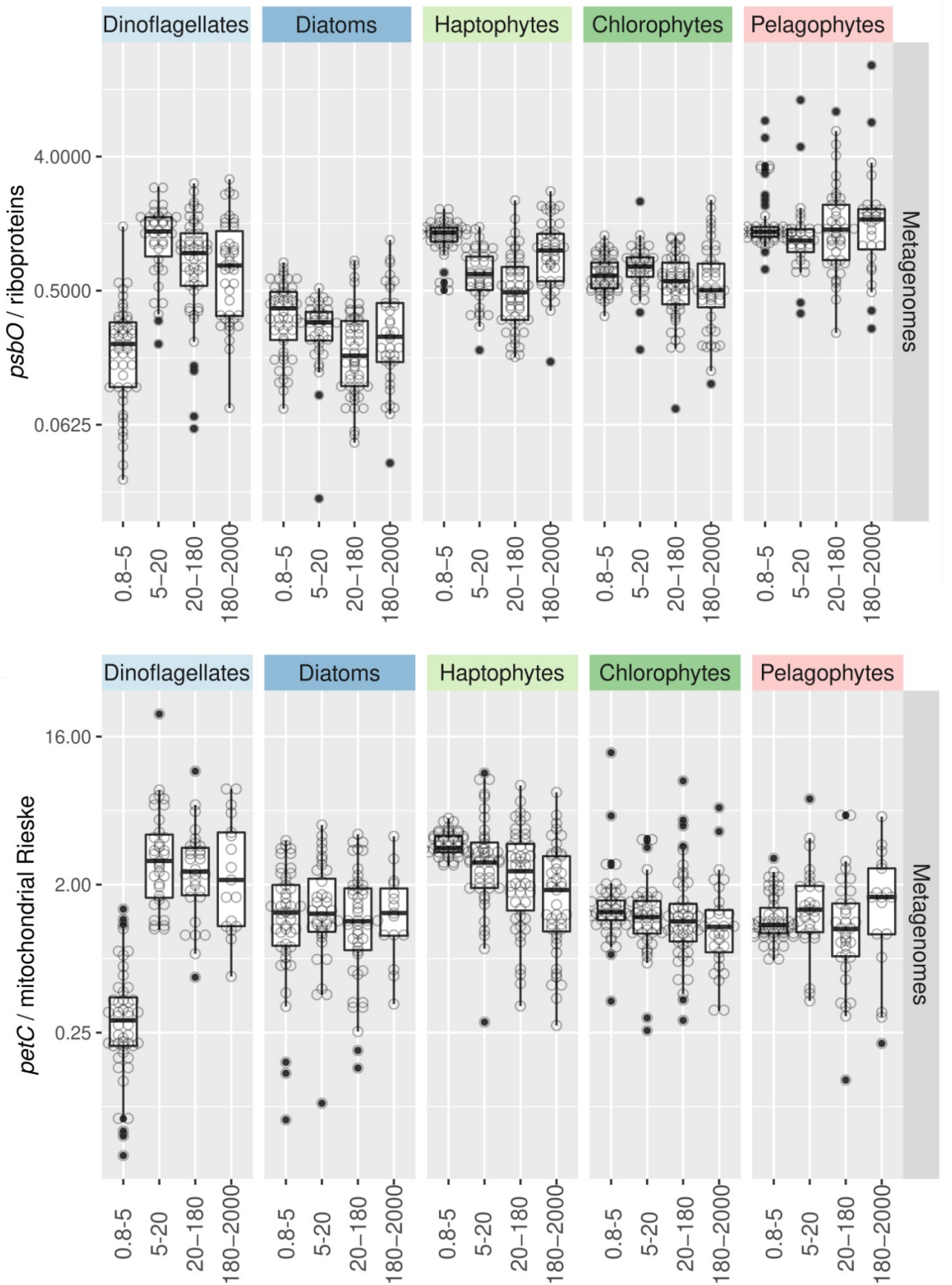

Figure S14: Variations in the abundance of phototrophs vs heterotrophs across size fractions based on different marker genes in metagenomes. The estimation were based on the ratio of metagenomic reads of photosynthetic vs housekeeping single-copy nuclear-encoded genes: $p s b O$ vs genes coding for ribosomal protein (upper panel), and the genes coding for the Rieske subunits of the Cyt bc-type complexes from chloroplasts and mitochondria (i.e., petC and its mitochondrial 


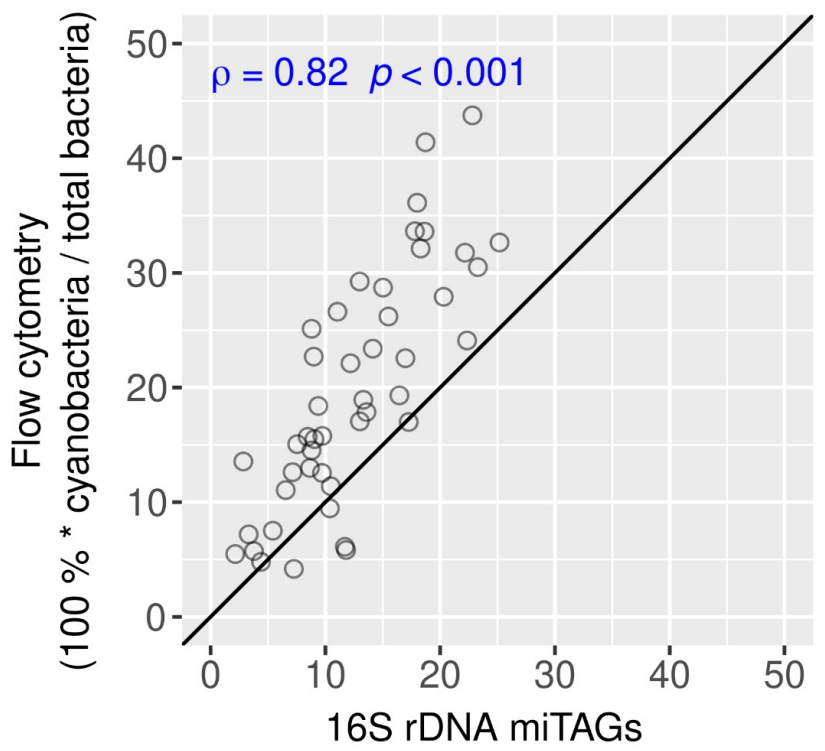

(100\% * cyanobacterial reads / bacterial reads)

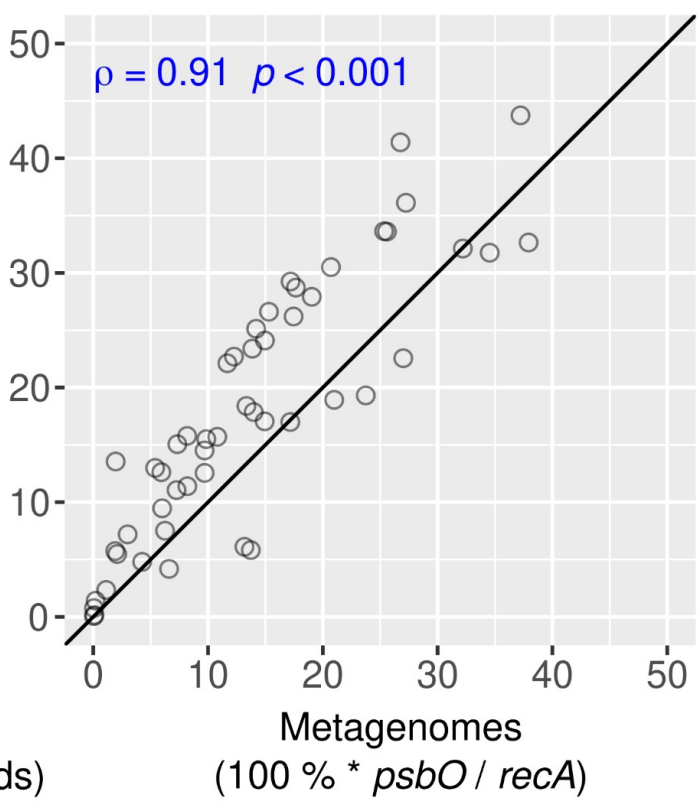

1469

1471

1472

1473

1474

1475

1476

1477

Figure S15: Congruence in the relative abundance of phototrophs among bacterioplankton in 0.2-3 size fraction based on different methods. The vertical axis corresponds to the relative cell abundance based on flow cytometry while the horizontal axis corresponds to the relative read abundance based on $16 \mathrm{~S}$ miTags (left) or on the ratio of $p s b O$ to $r e c A$ in metagenomes (right). Spearman correlation coefficients and p-values are displayed in blue. Axis are in the same scale and the diagonal line corresponds to a 1:1 slope. 
bioRxiv preprint doi: https://doi.org/10.1101/2021.05 28 446125; this version posted September 19, 2021. The copyright holder for this preprint (which was not certified by peer review) is the author/funder, who has granted bioRxiv a license to display the preprint in perpetuity. It is made available under aCC-BY 4.0 International license.
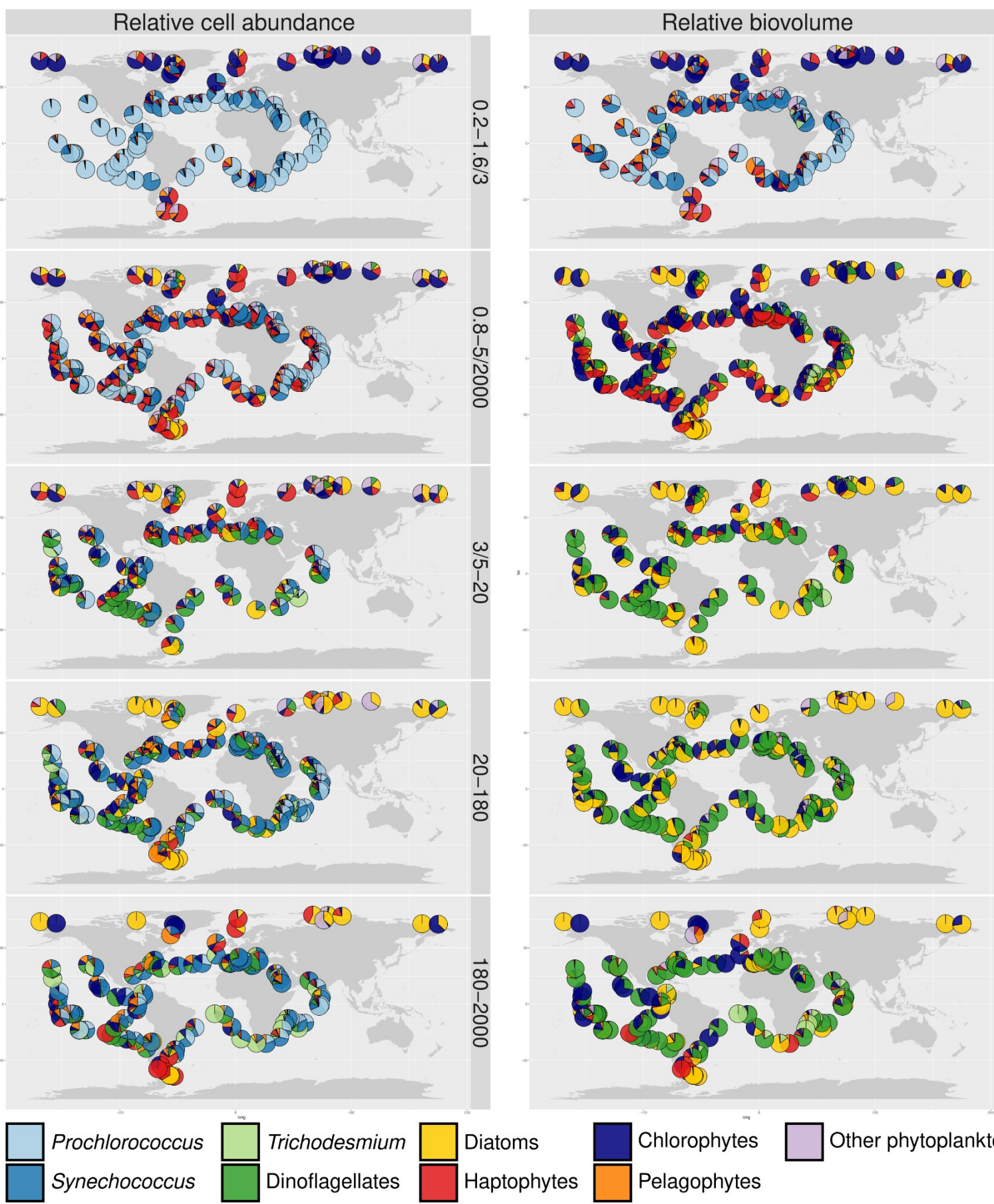

Figure S16: Global biogeographical patterns of relative cell abundance and biovolume for marine phytoplankton in surface waters. A) Relative cell abundances of the main cyanobacteria and eukaryotic phytoplankton based on $p s b O$ counts in metagenomes derived from different sizefractionated samples. B) Relative biovolume of the main cyanobacteria and eukaryotic phytoplankton based on $p s b O$ counts correctected by the mean cell biovolume for each taxon (based on optical measurements in Tara Oceans samples). 
bioRxiv preprint doi: https://doi org/10.1101/2021.05.28.446125; this version posted September 19, 2021. The copyright holder for this preprint (which was not certified by peer review) is the author/funder, who has granted bioRxiv a license to display the preprint in perpetuity. It is made available under aCC-BY 4.0 International license.
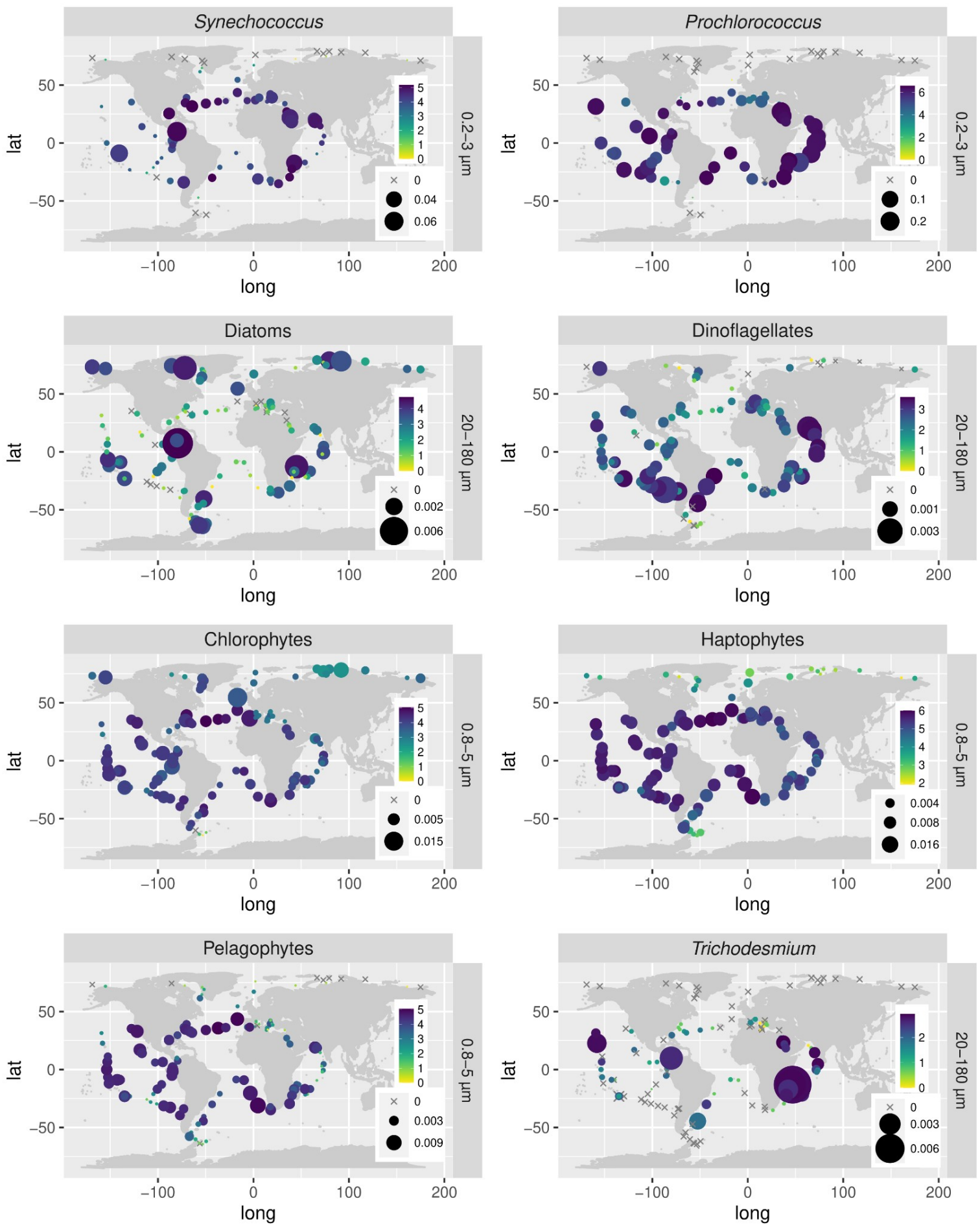

Figure S17: Global biogeographical patterns for main groups of marine phytoplankton in surface waters. The bubbles sizes vary according to the $p s b O$ relative abundance of the main cyanobacteria and eukaryotic phytoplankton in metagenomes, while color code corresponds to the Shannon index values. Relative abundance values are displayed as rpkm (reads per kilobase per million mapped reads). Only the size fraction where the corresponding taxon was prevalent is shown: 0.2-3 $\mu \mathrm{m}$ for picocyanobacteria, $20-180 \mu \mathrm{m}$ for diatoms and dinoflagellates, and $0.8-5 \mu \mathrm{m}$ for chlorophytes, haptophytes and pelagophytes. The corresponding analysis for the whole phytoplankton community in each size fraction is displayed in Figure 7. 